\title{
Hydrogeologic Appraisal of the Klamath Falls Geothermal Area, Oregon
}

GEOLOGICAL SURVEY PROFESIONAL PAPER $1044-G$

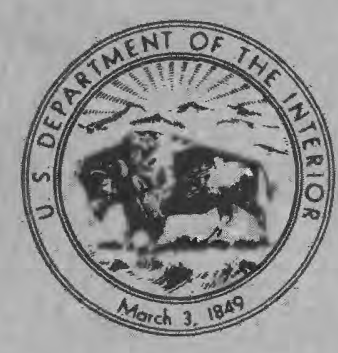





\section{Hydrogeologic Appraisal of the Klamath Falls Geothermal Area, Oregon}

By EDWARD A. SAMMEL

G E O H Y D R O L O G Y O F G E O T H E R M A L S Y S T E M S

GEOLOGICAL SURVEY PROFESSIONAL PAPER $1044-\mathrm{G}$

A description and evaluation of $a$

moderate-temperature hydrothermal

convection system

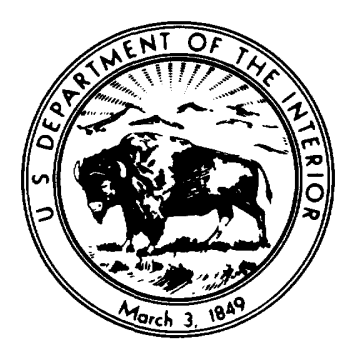

\begin{tabular}{llllll}
\hline UNITED & STATES & GOVERNMENT & PRINTING & OFFICE, & WASHINGTON
\end{tabular} 


\title{
UNITED STATES DEPARTMENT OF THE INTERIOR
}

CECIL D. ANDRUS, Secretary

\section{GEOLOGICAL SURVEY}

\author{
H. William Menard, Director
}

\footnotetext{
Library of Congress Cataloging in Publication Data

Sammel, Edward A.

Hydrogeologic appraisal of the Klamath Falls geothermal area, Oregon.

(Geohydrology of geothermal systems) (Geological Survey professional paper ; 1044-G)

Includes bibliographical references.

Supt. of Docs. no.: I 19.16:1044-G

1. Geothermal resources-Oregon-Klamath Falls region.

2. Water, Underground-Oregon-Klamath Falls region.

I. Title. II. Series. III. Series: United States. Geological Survey. Professional paper ; 1044-G.

GB1199.707S25

553.7

$80-607034$
}

For sale by the Superintendent of Documents, U.S. Government Printing Office Washington, D.C. 20402

Stock number 024-001-03300-3 


\section{CONTENTS}

\begin{tabular}{|c|c|c|c|}
\hline onversion of units of measurement & $\begin{array}{r}\text { Page } \\
\text { IV }\end{array}$ & Chemistry of ground water-Continued & Page \\
\hline bstract & G1 & Reservoir temperatures estimated from chemical geother- & \\
\hline troduction & 1 & mometers - & G25 \\
\hline Background and scope of study & 1 & Isotopes in ground water & 28 \\
\hline Methods of investigation & 2 & Oxygen-18 and deuterium isotopes & 28 \\
\hline Acknowledgments & 2 & Tritium concentrations & 30 \\
\hline tem for wells and springs & 2 & Isotope mixing models & 30 \\
\hline Units of measurement & 4 & Reservoir temperature estimated from oxygen isotopes & \\
\hline egional setting & 4 & lfate & 02 \\
\hline 1 geology and geothermal activity & 4 & d heat flow & 33 \\
\hline g- & 8 & ature & 33 \\
\hline nperature & 8 & perature & 33 \\
\hline - & 9 & $-\ldots$ & 37 \\
\hline (n)- & 10 & of heat & 38 \\
\hline d water & 10 & ons & \\
\hline -.- & 10 & lating to the geothermal resource & 38 \\
\hline ( & 12 & 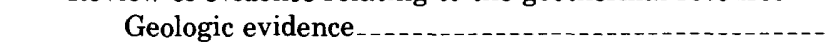 & 38 \\
\hline und water & 12 & ence & 39 \\
\hline Hydre & 14 & ce $\ldots . . .$. & 40 \\
\hline wells & 14 & the geothermal system - & 41 \\
\hline mping tests in wells & 15 & nal system & 42 \\
\hline hemi & 16 & of the geothermal resource & \\
\hline & 1 & References cited & \\
\hline olved constituents & 20 & & \\
\hline
\end{tabular}

\section{ILLUSTRATIONS}

[Plates are in pocket]

Plate 1. Map showing altitudes of water levels and lines of equal altitude on the water table.

2. Map showing specific electrical conductance and Stiff diagrams of the principal dissolved constituents in ground water.

3. Map showing temperature of ground water, depth of wells, and lines of equal temperature.

4. Graph showing temperature profiles measured in unused wells and heat-flow holes.

Figure 1. Index map showing the Klamath Falls area, locations of "hot-well" area, National Weather Service stations, and

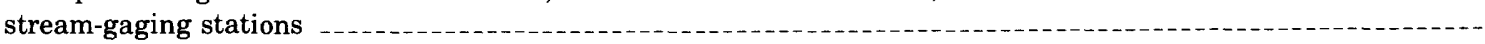

2. Diagram showing subdivision of township and range sections for well-numbering system

3. Map showing areal geology of the Klamath Falls area

4. Diagram showing profiles of wells at the Oregon Institute of Technology and Presbyterian Intercommunity Hospital, showing discordant water levels and assumed relations to faults -

5. Graph showing percent reacting values of major ions in ground water

6. Graphs showing log molal ratios of dissolved constituents in ground waters arranged in order of increasing chloride concentration

7. Graphs showing silica and chloride concentrations in ground water and their relations to observed water temperature

8. Graph showing temperature of ground water versus $\log$ silica concentration

9. Graph showing temperature of ground water versus $\log (\mathrm{Na} / \mathrm{K})+\beta \log (\sqrt{\mathrm{Ca}} / \mathrm{Na})$

10. Graph of $\delta$ oxygen-18 versus $\delta$ deuterium in ground water and lake water

11. Graph of chloride concentration versus $\delta$ oxygen-18 and $\delta$ deuterium in ground water and lake water

12. Graph showing mixing proportions of thermal and meteoric waters based on $\delta$ oxygen- 18 and $\delta$ deuterium relations and hypothetical geothermal reservoir waters

13. Geologic sketch map of the Klamath Falls area (after Peterson and McIntyre, 1970), showing locations and categories of wells in which temperature profiles were obtained. 


\section{TABLES}

TABLE 1. Mean annual precipitation and temperature measured at National Weather Service stations in the vicinity of Klamath Falls

2. Evapotranspiration in the Upper Klamath River basin, Oregon and California

Oregon and California _......... 9

3. Summary of ground-water discharge and use in the Klamath Falls area

4. Specific capacities of wells and estimates of transmissivity in aquifers of the Klamath Falls area

5. Chemical analyses of water from wells and springs

6. Ratios of dissolved constituents in ground water

7. Estimates of reservoir temperature based on chemical relations in ground water

8. Analyses of the isotopes oxygen-18, deuterium, and tritium in ground water and Klamath Lake water

9. Calculated silica and chloride concentrations and temperatures in the geothermal reservoir

10. Data related to temperature profiles obtained in unused wells and heat-flow holes

11. Mass and thermal-energy discharge in ground water from thermal springs and wells in the Klamath Falls area

\section{CONVERSION OF UNITS OF MEASUREMENT}

$$
\text { Used in }
$$

this report

\begin{abstract}
inch (in)
inch (in)

foot (ft)

mile
\end{abstract}

square foot $\left(\mathrm{ft}^{2}\right)$
acre

square mile $\left(\mathrm{mi}^{2}\right)$

acre-foot (acre-ft)

cubic mile $\left(\mathrm{mi}^{3}\right)$
gallons per minute
(gal min $^{-1}$ )
million gallons per day
(Mgal d $\mathrm{d}^{-1}$ )
feet per mile

(ft $\mathrm{mi}^{-1}$ )

\section{feet squared per day

$$
\left(\mathrm{ft}^{2} \mathrm{~d}^{-1}\right)
$$

gallons per minute per foot (gal $\mathrm{min}^{-1} \mathrm{ft}^{-1}$ )

degrees Celsius $\left({ }^{\circ} \mathrm{C}\right)$

degrees Celsius per kilometer

\author{
Multiply by
}

Length

25.40

2.540

0.3048

1.609

Area

0.0929

0.4048

2.590

Volume

$1.233 \times 10^{-3}$

4.168

Flow

0.06308

$3.785 \times 10^{3}$

Topographic gradient

0.1894

Transmissivity

0.0929

Specific capacity (wells)

0.2070

Temperature

1.8 (and add 32)

Thermal gradient

.05486
To obtain

millimeter ( $\mathrm{mm}$ ) centimeter $(\mathrm{cm})$

meter $(\mathrm{m})$

kilometer $(\mathrm{km})$

square meter $\left(\mathrm{m}^{2}\right)$ hectare (ha) square kilometer $\left(\mathrm{km}^{2}\right)$

cubic hectometer $\left(\mathrm{hm}^{3}\right)$ cubic kilometer $\left(\mathrm{km}^{3}\right)$

liters per second $\left(\mathrm{L} \mathrm{s}{ }^{-1}\right)$ cubic meters per day $\left(\mathrm{m}^{3} \mathrm{~d}^{-1}\right)$

meters per kilometer $\left(\mathrm{m} \mathrm{km}^{-1}\right.$ )

meters squared per day $\left(\mathrm{m}^{2} \mathrm{~d}^{-1}\right)$

liter per second per meter $\left(\mathrm{L} \mathrm{s}^{-1} \mathrm{~m}^{-1}\right)$

degrees Fahrenheit $\left({ }^{\circ} \mathrm{F}\right)$

degrees Fahrenheit per hundred feet ( ${ }^{\circ} \mathrm{F} / 100 \mathrm{ft}$ ) 


\section{CONTENTS}

Used in

this report

Multiply by
Thermal conductivity

millicalories per centimeter per second per degree Celsius (mcal cm $\mathrm{cm}^{-1} \mathrm{~s}^{-1}{ }^{\circ} \mathrm{C}^{-1}$ )

Specific heat (volumetric)

calories per cubic centimeter per degree Celsius

(cal $\mathrm{cm}^{-3}{ }^{\circ} \mathrm{C}^{-1}$ )

Heat flow

microcalories per square centimeter per second

(Heat flow unit $=$ HFU $)$

$\left(\mu \mathrm{cal} \mathrm{cm}^{-2} \mathrm{~s}^{-1}\right.$ )
0.4184

$4.184 \times 10^{6}$

To obtain

watts per meter

per degree Celsius
$\left(\mathrm{W} \mathrm{m} \mathrm{m}^{-1}{ }^{\circ} \mathrm{C}^{-1}\right)$

joules per cubic meter

per degree Celsius

(J $\mathrm{m}^{-3}{ }^{\circ} \mathrm{C}^{-1}$ )

$4.184 \times 10^{-2}$ watts per square meter (W m ${ }^{-2}$ ) 


\title{
HYDROGEOLOGIC APPRAISAL OF THE KLAMATH FALLS GEOTHERMAL AREA, OREGON
}

\author{
BY EDWARD A. SAMMEL
}

ABSTRACT

Geothermal phenomena observed in the vicinity of Klamath Falls include hot springs with temperatures that approach $96^{\circ} \mathrm{C}$ (the approximate boiling temperature for the altitude), steam and water wells with temperatures that exceed $130^{\circ} \mathrm{C}$, and hundreds of warmwater wells with temperatures ranging from $20^{\circ}$ to $40^{\circ} \mathrm{C}$. Although warm water is produced from wells scattered throughout most of the 350 -square-mile area studied, waters with temperatures exceeding $60^{\circ} \mathrm{C}$ are confined to three relatively restricted areas, the northeast part of the City of Klamath Falls, Olene Gap, and the southwest flank of the Klamath Hills.

The hot waters are located near, and are presumably related to, major fault and fracture zones of the Basin and Range type. The displaced crustal blocks are composed of basaltic flow rocks and pyroclastics of Miocene to Pleistocene age, and of sedimentary deposits and basalt flows of the Yonna Formation of Pliocene age. Dip-slip movement along the high-angle faults may have been as much as 6,000 feet at places.

Average annual precipitation in 7,300 square miles of the upper Klamath River basin surrounding the study area is about 18.2 inches, of which between 12 and 14 inches is estimated to be lost through evapotranspiration.

Ground water of local meteoric origin moves through the shallow sedimentary deposits and volcanic rocks at relatively slow rates. Within the older basaltic rocks of the area, hydraulic conductivities are greater than in the shallow sediments, and ground water may move relatively freely parallel to the northwest-southeast structural trend. A small amount of ground water, perhaps 100,000 acre-feet per year, leaves the area in flow toward the southwest, but much of the ground water is discharged as evapotranspiration within the basin.

The local meteoric water that is assumed to be the source of the thermal water in the area has low concentrations of dissolved-solids in which calcium and bicarbonate are the dominant ions. During its passage through the geothermal reservoir, concentrations of dissolved solids increase to about 900 milligrams per liter, and sodium and sulfate become the dominant ions. Chloride concentrations remain relatively low, and silica concentrations increase from an average of about 35 milligrams per liter to about 100 milligrams per liter.

The evidence from cation ratios, silica concentrations, and oxygen and deuterium isotopes in the hot waters indicates that temperatures in the near-surface geothermal reservoir are relatively low. The estimated minimum reservoir temperature, based on the quartz geothermometer and mixing models, is $150^{\circ} \mathrm{C}$. In contrast to these indications, the sulfate-oxygen isotope geothermometer indicates that, at some time in their history, the thermal waters have been exposed to temperatures approaching $200^{\circ} \mathrm{C}$, possibly in a deeper reservoir.
Temperature distributions and heat flows in the shallow rocks of the area are strongly influenced by convective flow of water. Most observed temperature gradients are unreliable indicators of depths to the geothermal reservoir. Heat flow in the vicinity of the geothermal areas has not been determined, but evidence from temperature profiles suggests that heat flow in the Lower Klamath Lake basin is about 1.4 microcalories per square centimeter per second (1.4 Heat flow units), a value that is near the minimum expected for the Basin and Range province.

The net thermal flux discharged from springs and wells in the area is estimated to be on the order of $2 \times 10^{6}$ calories per second. Discharge by thermal waters into the shallow ground-water system beneath land surface may be many times this amount. Reportedly, at present only about $1.4 \times 10^{6}$ calories per second ( 6 megawatts) of thermal energy is beneficially used in the area.

A conceptual model of the geothermal system at Klamath Falls suggests that most of the observed phenomena result from transport of heat in a convective hot-water system closely related to the regional fault system. Temperatures at shallow depths are elevated both by convective transport and by the blanketing effect of rocks of low thermal conductivity. Circulation of meteoric water to a depth of 15,000 feet could account for the estimated temperatures in the thermal reservoir, assuming conductive heat flow and a temperature gradient of $30^{\circ} \mathrm{C}$ per kilometer in the shallow crustal rocks. Circulation to shallower depths may be sufficient to warm the water to the required temperatures under the more probable conditions of convective transport of heat and the insulating effect of overlying sediments.

Heat content in the shallow hot-water system $(<10,000$ feet depth $)$ is probably in the range $15 \times 10^{18}$ to $190 \times 10^{18}$ joules, but is likely to be in the lower part of this range. This thermal energy may be stored in two or more separate reservoirs having a total volume not much greater than 12 cubic miles.

\section{INTRODUCTION}

\section{BACKGROUND AND SCOPE OF STUDY}

Geothermal phenomena in the vicinity of Klamath Falls consist of at least 7 thermal artesian springs and about 800 thermal wells. More than 400 of the wells are used for space heating, a use that began in the area about 50 years ago and is increasing rapidly at the present time. The amount of geothermal energy recovered from these wells and applied to nonelectrical use in the Klamath Falls area is probably one of the largest such applications in the United States. 
Rapid growth in the use of geothermal energy at Klamath Falls and plans for expanding this use have led in recent years to a need for increased knowledge of the physical properties of the geothermal system. As one of the steps toward meeting this need, the investigation described in this report was begun by the U.S. Geological Survey in 1973. General objectives of the study were to bring together the large amount of existing data and to add new information in such areas of deficiency as chemical characteristics, geothermal gradients, and heat flow. An open-file report containing data and preliminary conclusions from the study has been released (Sammel, 1976).

The area of intensive study for this report covers approximately 350 square miles of the Klamath River drainage basin (fig. 1), and includes all known thermal anomalies in the immediate vicinity of Klamath Falls. The major area of thermal use, the so-called "hot-well area" of northeastern Klamath Falls (fig. 1), was not studied in detail, however. Because of time constraints, an adequate study of this area of intensive use would have severely limited the overall view that might otherwise be gained in a wider coverage of the geothermal areas. Staff members of the Geo-Heat Utilization Center, Oregon Institute of Technology (OIT), are now investigating the urban geothermal area, supported in part by a grant from the Geothermal Research Program of the U.S. Geological Survey.

\section{METHODS OF INVESTIGATION}

This report is based to a large extent on information obtained in an inventory of more than 300 wells and 20 springs in the Klamath Falls area. In most of these wells and springs measurements were made, as appropriate, of depth, water level, discharge, temperature, and specific electrical conductance. Driller's logs are available for about two-thirds of the wells.

Chemical analyses were obtained for 35 samples of water from wells and springs. Concentrations of carbonate, bicarbonate, and $\mathrm{pH}$ were determined in the field and the remainder of the analyses were performed in Geological Survey laboratories. Relatively complete analyses of water from 22 additional sources were obtained from owners or from published data. Water was also collected from 24 sources for analysis of stable isotopes and tritium.

A small amount of detailed geologic mapping was done, but in general a map by Peterson and McIntyre (1970) provided adequate geologic information for this reconnaissance.

Four shallow hydrologic test holes were drilled in the Lower Klamath Lake valley to depths ranging from 223 to 463 feet. Two 600 -foot holes were drilled for heat-flow information. Temperature profiles were ob- tained by means of a thermistor probe in the 6 drill holes as well as in 41 unused water wells.

Additional geophysical data obtained during this investigation include gravity measurements at 103 stations in the Upper and Lower Klamath Lake basins and thermal infrared imagery obtained in aircraft flights over about 300 square miles of the area. The gravity measurements are described in the open-file report by Sammel (1976). The infrared imagery has not been completely processed and is not discussed in this report. Preliminary visual examination of computergenerated contour plots based on the imagery suggests that properly calibrated high-resolution infrared imagery may be useful as an exploration tool in areas of surficial convective thermal phenomena.

\section{ACKNOWLEDGMENTS}

The author wishes to acknowledge the assistance of many colleagues in the Geological Survey who provided services, advice, and inspiration. Aid received in the fields of water chemistry, isotope analysis, heat flow, and gravity investigations was particularly helpful. Gratitude is expressed to numerous other individuals and organizations who provided assistance and facilities during the study; special mention is made of the U.S. Bureau of Reclamation, Klamath Falls Project, for making facilities available and for help in ways too numerous to describe; the U.S. Forest Service, Winema Forest Headquarters, for facilities and aid; Jack Hitt and Professors J. W. Lund, G. G. Culver, P. J. Lienau, and L. S. Svanevik at the Oregon Institute of Technology for facilities and aid during a study of wells at OIT; J. B. Koenig and M. C. Gardner, Geothermex Co., for making data available and for providing initial insights into the geothermal system at Klamath Falls; and the hundreds of well owners who allowed us to visit, measure, and sample wells or, in some instances, to drill test holes on their property. Finally, special thanks are due to N. E. Voegtly who collected and compiled many of the data for this report.

\section{NUMBERING SYSTEM FOR WELLS AND SPRINGS}

In this report, wells and springs are numbered according to a system based on their location within townships, ranges, and sections referred to the Willamette Baseline and Meridian. Thus, the number 39/9-21 bcdl specifies a well in Township 39 South, Range 9 East, and Section 21. The letters which follow indicate respectively the $1 / 4,1 / 16$, and $1 / 64$ quadrants within the section according to the scheme illustrated in figure 2.

A number following the letters indicates that more than one well was inventoried in the same 1/64 section 
HYDROGEOLOGIC APPRAISAL OF KLAMATH FALLS GEOTHERMAL AREA, OREGON

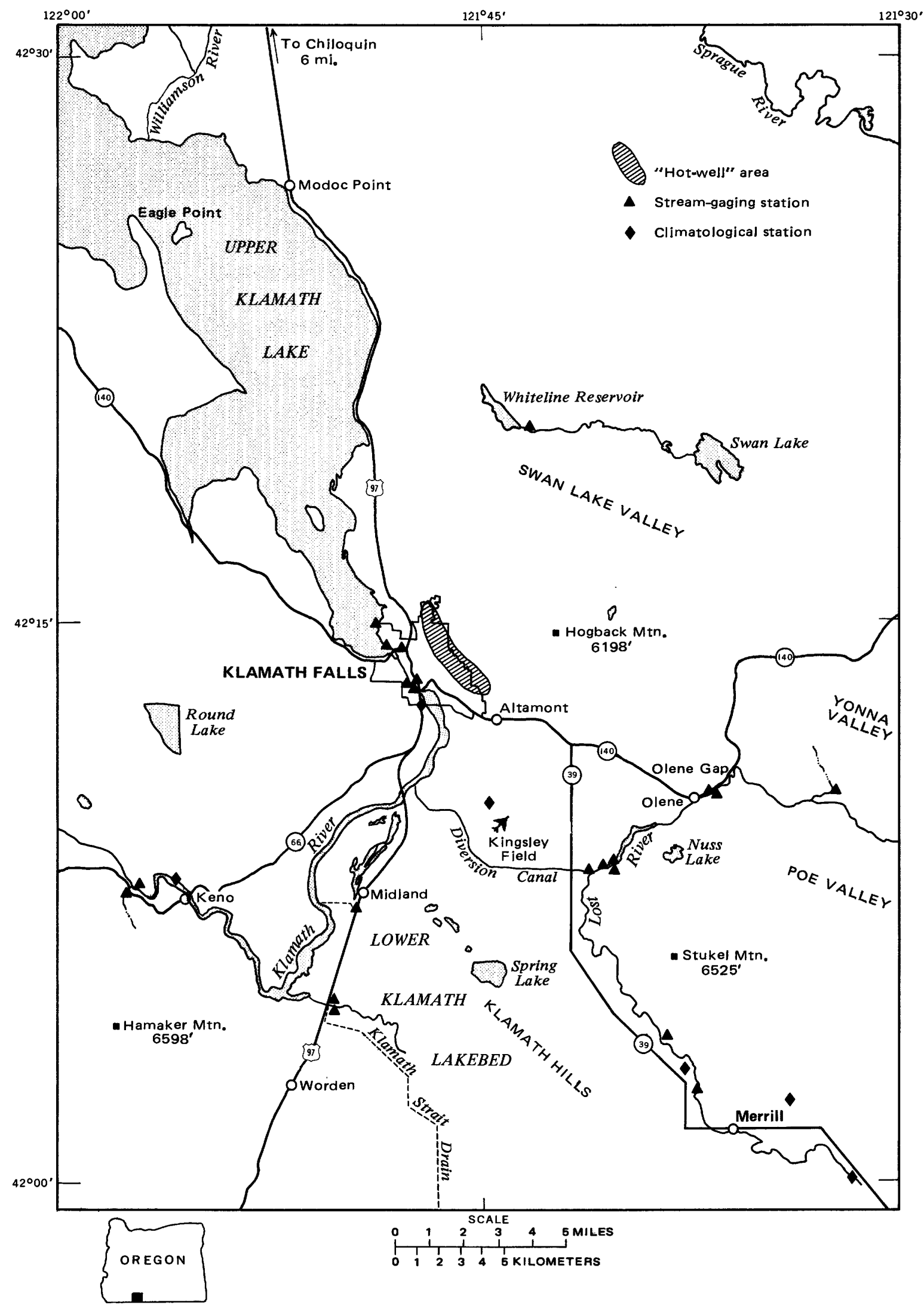

Figure 1.-The Klamath Falls area, locations of "hot-well" area, National Weather Service stations, and streamgaging stations. 


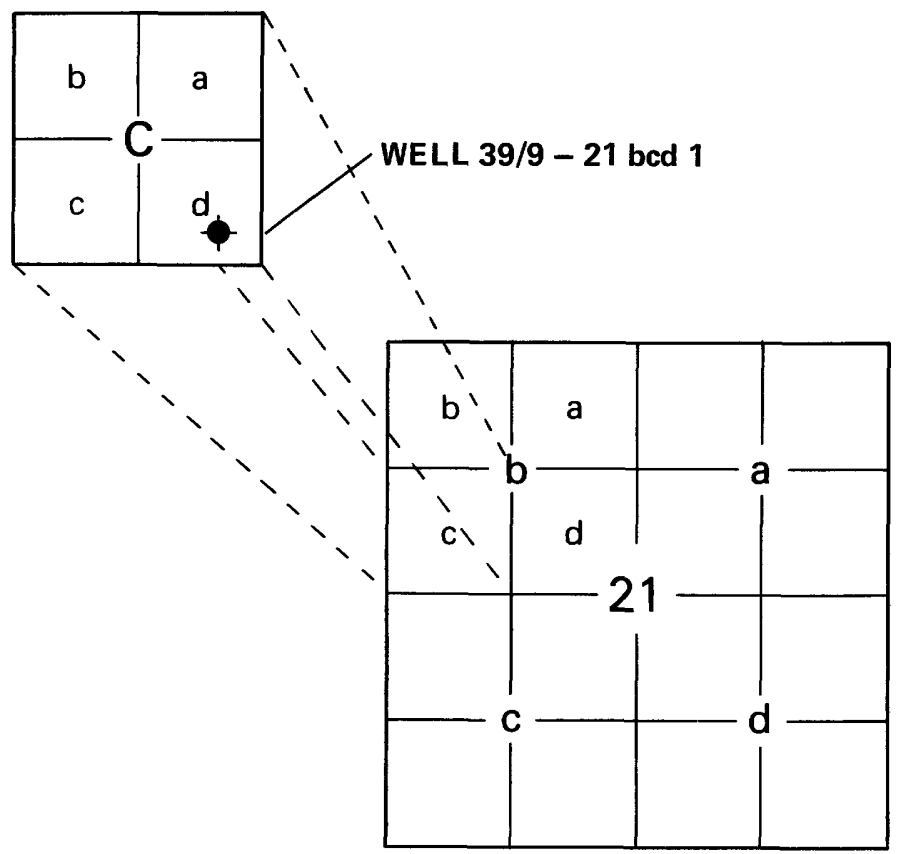

FIGURE 2.-Subdivision of township and range sections for wellnumbering system.

quadrant; such wells are numbered serially in chronological order of inventory. Each well number, therefore, specifies a location within a quadrant approximately 600 feet on a side. Most wells shown on the accompanying maps are located with a probable error of less than 300 feet.

\section{UNITS OF MEASUREMENT}

Most of the data obtained during this study were measured in the inch-pound system of units. For reasons of accuracy, as well as the convenience of most readers, these units have been retained in this report. A table of multipliers is provided for use in converting the inch-pound units to SI (metric) units.

Field measurements of water temperature were obtained in units of degrees Celsius $\left({ }^{\circ} \mathrm{C}\right)$, and for the sake of consistency, the few reported temperatures have been converted to this system. Air temperatures reported by the National Weather Service are in ${ }^{\circ} \mathrm{F}$. In the fields of geothermal gradients and heat flow, most current scientific reports use SI units or other established metric equivalents. In order to retain temperature measurements in degrees Celsius and provide a convenient basis for comparison of calculated results, sections of this report dealing with these subjects contain commonly used metric units rather than inchpound units. Thus, geothermal gradients are reported in degrees Celsius per kilometer, thermal conductivities are in milicalories per centimeter per second per degree Celsius, and heat flow is in microcalories per square centimeter per second (heat flow units). Conversion factors for these units are provided in the table of units. The metric unit, kilometer, is used in the section, "Magnitude of the Geothermal Resource," in order to facilitate comparison of estimates made there with previously published estimates.

\section{REGIONAL SETTING}

\section{REGIONAL GEOLOGY AND GEOTHERMAL ACTIVITY}

Geologic structures in the Klamath Falls area are typical of the Basin and Range province (Gilbert, 1928). Large grabens form the Upper and Lower Klamath Lake basins; these basins are flanked by uplifted blocks bounded by steeply-dipping normal faults. The regional structure has a northwestsoutheast alinement, but numerous faults have northsouth strikes, and a few strike northeast-southwest.

Figure 3 shows geologic units and major faults in the Klamath Falls area as mapped by Peterson and McIntyre (1970). The oldest rocks exposed in the area are of latest Tertiary age; they include lacustrine and fluvial tuffaceous siltstone, sandstone, ashy diatomite, basaltic tuff and breccia, and a few thin basalt flows. These rocks were grouped by Newcomb (1958) in the Yonna Formation of Pliocene age. Later investigators have been reluctant to use this formation name because of uncertainties regarding the stratigraphic boundaries of the formation and the specific rock sequences that should be included. The name is used in this report for convenience in referring to groups of rocks of the type and age described by Newcomb.

Rocks of the Yonna Formation underlie the lower slopes of many upraised fault blocks in the area and occur at depth beneath most of the lacustrine and alluvial sediments in the structural basins. Ashy diatomites of the formation are conspicuous in roadcuts and quarries and are penetrated by many wells.

The most prevalent rocks of the Yonna Formation are thick, massively bedded, coarse-grained palagonitic sediments and pyroclastic rocks which are not clearly related to specific eruptive centers. Examples of these rocks are exposed in two large fault blocks south and east of Klamath Falls, Stukel and Hogback Mountains. Interbedded with the volcanic sediments are thin basaltic lavas which are generally dense, black, glassy, and vesicular. Some, such as those exposed at the Klamath Rock Products quarry (T39, R8, Sec. 11), are brecciated and altered owing to extrusion into water or wet diatomaceous ooze (Peterson and McIntyre, 1970). These flows probably issued from nearby fissures which were subsequently covered. The occurrence of local volcanic activity is also indicated by a few scattered maar and tuff-ring deposits. 
Massive diatomites of the Yonna Formation have counterparts in Butte Valley, California, about 20 miles southwest of Klamath Falls, where they underlie Pliocene volcanic rocks of the High Cascades (Moore, 1937; Wood, 1960). Near Klamath Falls, diatomites are interbedded with Pliocene volcanic rocks (Meyers and Newcomb, 1952). The entire area over which diatomites are found is not known to have been covered by a continuous water body, but the lake, or lakes, must have been extensive.

Thickness of the Yonna Formation beneath the valley floors is largely unknown, but in adjacent ridges it ranges from a few feet to at least 850 feet. The maximum thickness is inferred from the driller's log of a well at the Presbyterian Intercommunity Hospital, located about 1 mile north of Klamath Falls.

Rocks older than the Yonna Formation do not crop out in the vicinity of Klamath Falls. The characteristics of these older rocks are known, however, from drillers' logs, and the probable ages of the rocks may be inferred from geologic mapping in adjacent areas. A few miles east of Klamath Falls in Swan Lake, Yonna, and Poe Valleys, the Yonna Formation lies unconformably on olivine basaltic rocks of probable Pliocene age (Peterson and McIntyre, 1970; Leonard and Harris, 1974). The basalt is blue-gray to gray-brown, vesicular, and columnarly jointed. Individual flows are as much as 30 feet thick and are interbedded with tuff and scoriaceous flow breccia (Leonard and Harris, 1974). Maximum observed thickness of the unit is about 300 feet in the Yonna Valley.

Pliocene basaltic flows also underlie extensive areas of the Warner Range, about 80 miles east of Klamath Falls. They dip westward for the most part and probably underlie tuffs and lacustrine deposits of the Sprague River valley about 35 miles northeast of Klamath Falls (Peterson and McIntyre, 1970). These large volumes of basaltic lavas and pyroclastics were extruded onto relatively level surfaces in the region surrounding Klamath Falls during late Pliocene time. Similar flows probably also covered the Klamath Falls area. They are recorded in drillers' logs as massive gray to brown vesicular basalt and tuffaceous sediment that underlie the Yonna Formation at places such as the Oregon Institute of Technology, about 2 miles north of Klamath Falls, at the Oregon Water Corporation wells in Klamath Falls, and possibly at a 1,300 foot well on Hamaker Mountain south of Keno. Similar rocks crop out in the Klamath River canyon southwest of Klamath Falls where their thickness is at least 800 feet (Newcomb and Hart, 1958).

The Pliocene olivine basalts described above probably correlate with extensive basaltic lavas that occur in adjacent areas of northern California (Wood, 1960).
These rocks are older basalts of the High Cascades mapped in Butte Valley, California (Wood, 1960), and in the Macdoel Quadrangle, Calif. (Williams, 1949). According to Williams, the large shield volcanoes of the High Cascades that dominate the eastern margin of the Cascade Range were probably extruded from north-south trending fissures during a period extending from late Pliocene to Holocene time. The flows are composed largely of olivine-augite basalt, although andesite flows and related pyroclastic rocks are commonly interbedded. The major flows dip eastward and are buried by younger basalts and pyroclastic rocks in the hills immediately west of Klamath Falls.

West of the High Cascade volcanoes, a belt of volcanic rocks from 30 to 40 miles wide forms the Western Cascades. These rocks, consisting largely of pyroxene andesites, olivine basalts, and rhyolite tuffs and lava domes, were uplifted, folded, and deeply dissected prior to the High Cascade eruptions. With ages ranging from Eocene to Pliocene (Williams, 1949), the rocks are equivalent to the Clarno Formation, John Day Formation, Columbia River Basalt Group, and the Cedarville Series of Russell (1928) in the Warner Range of northeastern California.

At places, such as Oregon-Calfornia border west of Klamath Falls, the thickness of the Western Cascade rocks is at least 12,000 feet (Williams, 1949, p. 20). Although these rocks dip to the east beneath the High Cascades, they do not crop out in the vicinity of Klamath Falls and have not been penetrated by wells there.

Depth of occurrence and characteristics of preTertiary rocks in the Klamath Falls area are unknown. The oldest rocks exposed in adjacent regions are metacherts and quartzites of probable Paleozoic age intruded by quartz monzonites of Jurassic age near the foot of Mount Shasta (Williams, 1949, p. 14). The Chico Formation (Cretaceous), consisting of marine arkosic sandstone, conglomerate, and shale, underlies parts of the Macdoel Quadrangle in northern California. Hot springs that occur in the Macdoel Quadrangle about 30 miles southwest of Klamath Falls have high chloride concentrations that may indicate the presence of the Chico Formation at this location (Williams, 1949, p. 55). It is possible, therefore, that marine sedimentary rocks also underlie the Klamath Falls area, although no evidence of the presence of such rocks is known.

The structural development of the Klamath Falls area may have begun with normal faulting as early as Pliocene time (Peterson and McIntyre, 1970, p. 28). Subsequent to the deposition of the Yonna sediments and contemporaneous basalt flows, the entire region was apparently folded into broad anticlines and synclines with generally north-south axial trends. The 


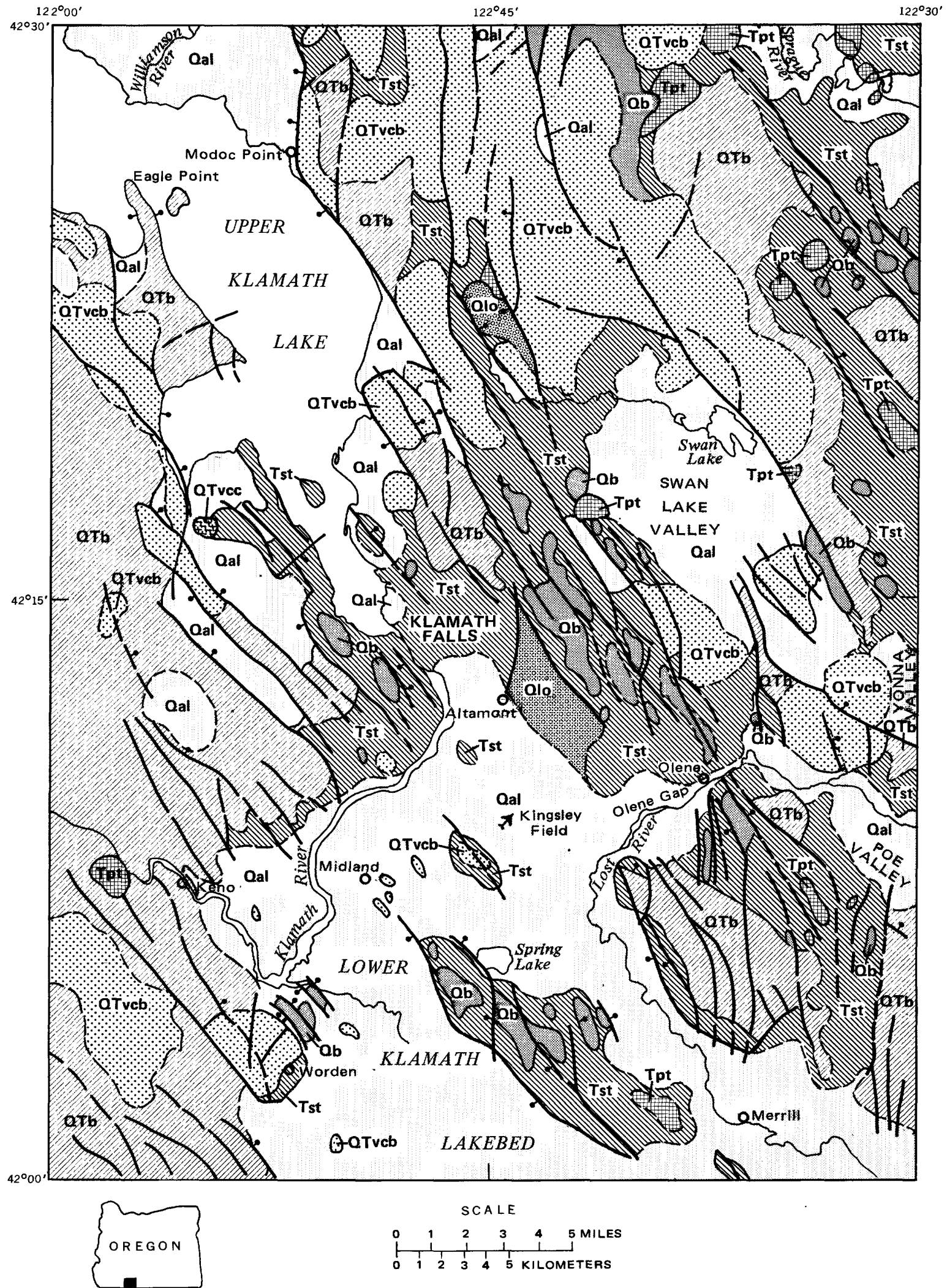

Figure 3.-Areal geology of the Klamath Falls area. (Modified from Peterson and McIntyre, 1970.) 


\section{CORRELATION OF MAP UNITS}

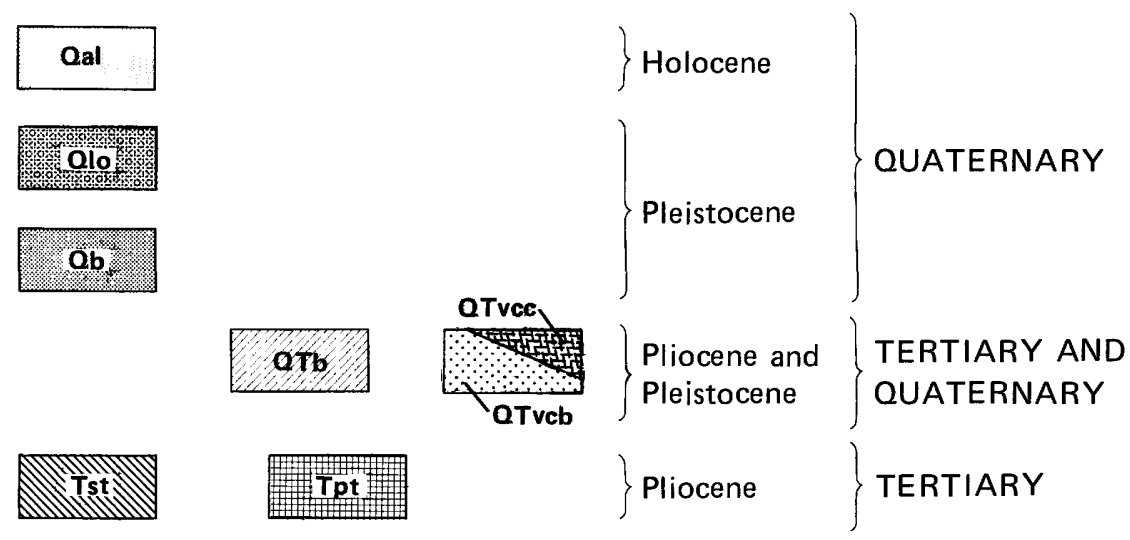

DESCRIPTION OF MAP UNITS

Qal

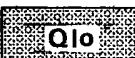

Q10

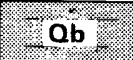

otb

Basalt flows, pyroclastic breccia, and agglomerate, of uncertain and $\mathrm{Qb}$

QTucto

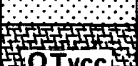

10Trectu

Basaltic eruptive centers

Basaltic cinder cones

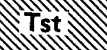

Lacustrine and fluviatile tuffaceous siltstone, sandstone, ashy diatomite, basaltic tuff and breccia, few thin basalt flows $=$ Yonna Formation)

Maar and tuff-ring deposits

\footnotetext{
-- Contact - Dashed where approximate

- - Fault - Dashed where approximate. Ball on downthrown side
}

Note: Description of map units and map symbols are quoted from Peterson and McIntyre, 1970

Figure 3.-Continued.

Sycan Marsh-Bly-Beatty area lay in a broad syncline, and the present Summer Lake-Goose Lake graben was an anticline. The Klamath Falls area may also have been an anticline whose crest subsequently dropped to form the present graben (Peterson and McIntyre, 1970, p. 29).
The volcanic activity and faulting that produced the present topography in the Klamath Falls area occurred mostly during the Pleistocene. To the west, new volcanic vents continued to form in the High Cascades, and stratovolcanoes such as Mts. Shasta, McLoughlin, and Mazama were built. Near Klamath Falls, wide- 
spread thin basalt flows were extruded over the Pliocene lacustrine sediments. Exposures of these vesicular, medium to dark gray, diktytaxitic Pleistocene basalts occur in the Klamath Hills, on Stukel Mountain south of Olene Gap, and on Hogback Mountain east of Klamath Falls. The cataclysmic eruption of Mount Mazama, about 6,700 years ago, produced thick deposits of ash and pumice that mantle the northern part of the area.

Large volumes of Quaternary and Tertiary basalt flows and breccias of uncertain stratigraphic relationships underlie some of the highest ridges near Klamath Falls. These rocks may in part be contemporaneous with the Pliocene Yonna Formation, but in part are Pleistocene. Normal faults cut all the above units, as well as the rocks of basalt eruptive centers that form some of the higher isolated hills.

The present-day basins of the Klamath Falls area were probably established early in Pleistocene time as the result of tensional fracturing of the entire region. Fluvial-terrace and lacustrine sediments deposited in these basins are now found at altitudes as high as 200 feet above the present valley floor, presumably as the result of high lake levels in late Pleistocene time. Some of these deposits are deformed by faults, indicating that deformation continued into late Pleistocene time (Peterson and McIntyre, 1970, p. 19). It is not certain, therefore, that the present levels of these deposits represent original altitudes of lake shorelines.

Basin and Range faulting in the Klamath Falls area reached a climax during Pleistocene time. Movement was almost entirely dipslip along steeply-dipping $\left(>60^{\circ}\right)$ normal faults. The maximum displacement is at least 980 feet and may be as much as 6,000 feet if current interpretations of gravity data are accepted (D. L. Peterson, 1976). Some seismic activity has occurred in the region during historical times, but no historical surface breaks have been recorded (Couch and Lowell, 1971, p. 67).

Thermal wells and springs are widespread in the Klamath Falls area. In this report, a thermal water is defined as one having a temperature $\geqslant 20^{\circ} \mathrm{C}$, or about $8^{\circ} \mathrm{C}$ above the average temperature of shallow ground water. Known hot waters, with temperatures greater than $60^{\circ} \mathrm{C}$, are confined to the following three locations: (1) an area of about $2 \mathrm{mi}^{2}$ along the northeast edge of the city; (2) a stream-cut gap in the hills about 8 miles southeast of the city at Olene Gap; and (3) the southwest flank of the Klamath Hills, about 12 miles south of the city. These three areas are referred to in subsequent sections of the report as the "principal geothermal areas."

The highest-temperature geothermal manifestations include several springs with temperatures that are near the boiling point (less than approximately $96^{\circ} \mathrm{C}$ ), a few hot-water wells with subsurface temperatures that exceed the boiling point, and a few steam wells. One exceptionally hot well had a bottom-hole temperature when drilled of about $140^{\circ} \mathrm{C}$. Most of the wells having temperatures greater than $60^{\circ} \mathrm{C}$ are located in the city's hot-well area. In hundreds of other wells scattered through the lower Klamath Falls basin, water temperatures range from just above normal for the region $\left(15^{\circ} \mathrm{C}\right)$ to about $40^{\circ} \mathrm{C}$.

The principal geothermal phenomena in the area are spatially related to fault zones. All waters known to have temperatures greater than $65^{\circ} \mathrm{C}$, for example, occur within 1 mile of major faults. The association of the Klamath Falls geothermal phenomena with Basin and Range type faults suggests an anology with other geothermal areas of the Basin and Range province such as Warner Valley, Ore., Surprise Valley, Calif., and the many large fault-controlled hot-water systems in Nevada.

Each of the principal geothermal areas in the vicinity of Klamath Falls contains extensive areas of silicified rocks as evidence that hydrothermal activity was formerly more widespread than at present. Some of these rocks, such as the silicified palagonite tuff that crops out above the Presbyterian Intercommunity Hospital, occur at altitudes as much as several hundred feet higher than any present surface flows of hot water. This evidence suggests that hydraulic heads in the major hydrothermal system were formerly much higher than at the present time or, alternatively, that hydrothermal activity preceded most of the displacement along the fault zones. The latter alternative appears to be the more likely, but the question has not been resolved by this study.

The ultimate source of heat for the geothermal waters is not known. Peterson and McIntyre (1970, p. 37) refer to the presence of dikes, intercalated sill-like masses, bleached and silicified rocks, deposits of calcite and gypsum, and a halo of mercury mineralization as suggesting the existence of a hot igneous mass at depth. An alternative explanation, proposed by the author, that involves only deep circulation of meteoric water is discussed below under the heading "Conceptual Model of the Geothermal System."

\section{CLIMATE AND DRAINAGE}

PRECIPITATION AND TEMPERATURE

Mean annual precipitation at six stations in the vicinity of Klamath Falls is shown in table 1 for the period of record available. The range of annual precipitation at a given station is relatively great. The range between stations is also great with a low of 11.8 inches 
TABLE 1.-Mean annual precipitation and temperature measured at National Weather Service stations in the vicinity of Klamath Falls

\begin{tabular}{|c|c|c|c|c|}
\hline Station & $\begin{array}{c}\text { Altitude } \\
\text { fft above } \\
N G V D \text { of } 1929\}\end{array}$ & $\begin{array}{l}\text { Period of } \\
\text { record used }\end{array}$ & $\begin{array}{l}\text { Mean annual } \\
\text { precipitation } \\
\text { (in) }\end{array}$ & $\begin{array}{l}\text { Mean annual } \\
\text { temperature } \\
\left({ }^{\circ} \mathrm{F}\right)\end{array}$ \\
\hline Chiloquin & $-4,198$ & $1948-73^{\mathrm{a}}$ & 18.13 & 42.9 \\
\hline Keno & $-4,116$ & $1948-73^{\mathrm{b}}$ & 19.49 & \\
\hline Kingsely Field & $-4,085$ & 1949-73 & 11.93 & 46 \\
\hline Klamath Falls & $-4,098$ & $1948-73$ & 14.37 & 48.0 \\
\hline Merrill & $-4,080$ & $1953-66^{\mathrm{b}}$ & 11.80 & \\
\hline Rocky Point & $-4,150$ & $1967-73^{\mathrm{c}}$ & 23.15 & 44.6 \\
\hline
\end{tabular}

aPartial records for years 1964,1968 , and 1971 completed by estimates based on correlations with other stations.

Record for 1964 estimated by correlation with other stations.

cPartial record for 1968 completed by internal correlation.

at Merrill and a high of 23.15 inches at Rocky Point. Outside the study area, extremes in this part of the Klamath River basin range from less than 10 inches at Tule Lake, Calif., to more than 60 inches on the highest peaks north and west of Klamath Falls.

Local orographic effects largely determine the relative amounts of precipitation. Thus, of the moisture that reaches the area after passing over the Cascades on the westerly winds, most falls on the highlands and a relatively small amount reaches the valley floors.

In most years, between 60 and 70 percent of the total precipitation falls during the months October through March. Most of this moisture is in the form of snow, although midwinter rains are frequent in the valley.

Based on rainfall maps published by the Oregon State Water Resources Board (1971), average annual precipitation in the drainage basin above Klamath Falls, including subbasins of the Williamson River, Sprague River, and Upper Klamath Lake, is calculated to be 22 inches over $3,820 \mathrm{mi}^{2}$. For the basin below Klamath Falls, precipitation is calculated to be about 15 inches over $3,497 \mathrm{mi}^{2}$. The area of this estimate includes the Lost River subbasin of Oregon and California but excludes the Meiss Lake closed basin southwest of Dorris, Calif. On the basis of the above calculations, the average annual precipitation in the four subbasins near Klamath Falls is 18.6 inches over $7,317 \mathrm{mi}^{2}$.

Mean annual air temperatures at stations near Klamath Falls are given in table 1. Stations with reported air temperatures are located at relatively low altitudes and mean annual temperatures at greater altitudes are undoubtedly considerably lower than those reported at the weather stations. No estimate of mean annual air temperature has been made for this part of the basin.

Measured temperatures of nonthermal ground water in shallow aquifers near Klamath Falls range from $7^{\circ}$ to $19^{\circ} \mathrm{C}$. Temperatures at individual sites may vary $5^{\circ} \mathrm{C}$ or more annually. The mean annual ground-water temperature at most places is probably several degrees higher than mean annual air temperatures, and the average temperature of shallow groundwater in the area is estimated to be about $12^{\circ} \mathrm{C}$.

\section{EVAPOTRANSPIRATION}

Estimates of evapotranspiration in the Upper Klamath River basin are given in table 2. Rates of evapotranspiration in the region are low owing to the relatively cool average temperatures and the low rainfall. Minimum rates may occur in the high dry valleys of the eastern part of the basin, where evapotranspiration from sage and prairie vegetation is probably less than 1 foot per year (virtually the total precipitation). Maximum evapotranspiration may be as much as 3 feet per year from widespread marshes and ponds in the upper basin.

For the upper Klamath Lake basin, including the three subbasins above Klamath Falls $\left(3,802 \mathrm{mi}^{2}\right)$, evapotranspiration is estimated to be 1.1 feet per year. This estimate includes the effects of an estimated ground-water outflow from the upper Klamath Lake basin of 25,000 acre-feet per year (Illian, 1970). If, as a lower limit, ground-water outflow is assumed to be one-half Illian's estimate, the calculated evapotranspiration is 1.2 feet per year.

For the Lost River subbasin in Oregon and California $\left(3,497 \mathrm{mi}^{2}\right)$, evapotranspiration is calculated to be 15 inches per year. The calculation includes Illian's estimate that ground-water flow from the upper Klamath Lake basin into the lower basin is 200,000

TABLE 2.-Evapotranspiration in the Upper Klamath River basin, Oregon and California

\begin{tabular}{|c|c|c|c|}
\hline Type of area & $\underset{\left(\mathrm{mi}^{2}\right)}{\text { Area }} \mathbf{E}$ & $\begin{array}{l}\text { Evapotranspiration } \\
\left(\mathrm{ft}^{\mathrm{y}} \mathrm{yr}^{-1}\right)\end{array}$ & $\begin{array}{l}\text { Source of } \\
\text { estimate }\end{array}$ \\
\hline $\begin{array}{l}\text { High, dry valleys-sage and } \\
\text { prairie grass. }\end{array}$ & & $<1$ & A \\
\hline Marshland & 56 & 3.6 & O \\
\hline Low valleys-irrigated crops & .422 & 1.3 & $\mathrm{O}$ \\
\hline $\begin{array}{l}\text { Upper Klamath Lake } \\
\text { (altitude } 4,139 \mathrm{ft} \text { ) }\end{array}$ & $-{ }^{1} 125$ & $3 \frac{1}{1 / 2}-4$ & $\mathrm{O}$ \\
\hline $\begin{array}{l}\text { Clear Lake (Calif.) } \\
\text { (altitude } 4,470 \mathrm{ft} \text { ) }\end{array}$ & 69 & $2^{1 / 2}-3^{1 / 2}$ & 0 \\
\hline $\begin{array}{l}\text { Upper Klamath River } \\
\text { basin: Sprague, Williamson, } \\
\text { and Upper Klamath } \\
\text { Lake subbasins }\end{array}$ & 3,820 & ${ }^{2} 1.1$ & A \\
\hline $\begin{array}{l}\text { Lost River subbasin } \\
\text { (Ore. and Calif.) }\end{array}$ & 3,497 & ${ }^{3} 1.3$ & A \\
\hline
\end{tabular}

A. Author (this report)

O. Oregon State Water Resources Board (1971)

L. Leonard and Harris (1974)

'Range 100 to $140 \mathrm{mi}^{2}$, depending on seasonal change in lake stage.
'Calculated from precipitation data (table 1), published streamflow records (U.S. Geological Survey), and unpublished canal-flow records (U.S. Bureau of Reclamation). Estimates of ground-water outflow from the Upper Klamath Lake and Sprague River subbasins (Illian, 1970) have been included in the calculation.

${ }^{3}$ Calculated from precipitation data (table 1) and published streamflow records for the Klamath River at Keno and Boyle Power Plant (U.S. Geological Survey). Estimates of ground-water flow into the Lost River subbasin (Illian, 1970 ) have been included, along with
the author's estimate of ground-water outflow below Keno. 
acre-ft per year and the author's estimate that about 100,000 acre-ft of water leaves the lower basin as ground-water flow. It is assumed that ground-water flow from the south end of the basin in California is negligible and that ground-water discharge occurs almost entirely through fractured rocks in the Klamath River gorge below Keno.

\section{SURFACE WATER}

Three major streams, the Sprague, Williamson, and Wood Rivers, drain the upper Klamath River basin above Klamath Falls. The Williamson and Wood Rivers flow into Upper Klamath Lake and the Sprague River is a tributary to the Williamson. Upper Klamath Lake is also fed by springs and seeps in or near the lake and by small tributaries on its periphery. The average annual flow from all the above sources for the period $1930-68$ is estimated to about $1,400,000$ acre-ft (Oregon State Water Resources Board, 1971, table 21).

Upper Klamath Lake, the largest natural lake in Oregon, has a surface area that varies between 100 and $140 \mathrm{mi}^{2}$, depending on seasonal changes in lake stage, and a length of about 22 miles. Agency Lake, $6^{1 / 2}$ miles in length, is appended to the north end of Upper Klamath Lake. The average depth of Upper Klamath Lake is only 8 feet, although depths reach 40 to 50 feet in a narrow trench between Eagle Ridge and Bare Island (Hubbard, 1970). Because of its shallow depth, regulated outflow, and generally warm water, Upper Klamath Lake is undergoing relatively rapid eutrophication.

Water from Upper Klamath Lake flows through a narrow strait on the western edge of the city of Klamath Falls, meanders through marshlands toward the southwest, and then, after passing over a dam near the town of Keno, leaves the area through a narrow gorge cut into bedrock. Below Klamath Falls, the stream becomes the Klamath River. Average annual flow at Keno for the period 1921-75 is 1,234,000 acre-ft (U.S. Geological Survey, 1976).

More than 300,000 acre-ft of water is diverted annually from Upper Klamath Lake and the Klamath River above Keno. This water is conveyed through three canals, the "A," the North, and the Ady, for use in irrigating lands in the Lower Klamath Lake basin. The canals are part of a major drainage and irrigation scheme built and, for the most part, operated by the U.S. Bureau of Reclamation (USBR). The project was begun in 1904 and is one of the oldest USBR projects in existence.

Southwest of Klamath Falls, the Lost River enters the Lower Klamath Lake valley through Olene Gap and flows into California. This stream has been incorporated in the USBR irrigation project, and its flow is now totally regulated. From a diversion dam north of Stukel Mountain, water is either diverted to the Klamath River or is returned to the Lost River channel for use downstream. About 116,000 acre-ft of water from the Lost River is annually distributed in the lower valley.

The network of canals and laterals that now serve the USBR Klamath Project totals about 700 miles in length and irrigates about 200,000 acres of land in Oregon and California. Tailwater flows southward to a closed basin in the vicinity of Tulelake, Calif. The extent of the water surface in this swamp area is closely regulated; excess water is pumped back to the north through the Klamath Straits Drain into the Klamath River. About 108,000 acre-ft of water is annually pumped out of the Tulelake area in addition to an average net flow of 141,000 acre-ft diverted to the Klamath River from the Lost River through the Lost River Diversion Channel.

In 1909 the Southern Pacific Railroad dike was completed along the west side of the lower lake valley, separating the marshland in the valley from the Klamath River. Since this time the Lower Klamath Lake in Oregon and California has been essentially a closed basin. It is likely, in fact, that the Tulelake area acted as a sump for some thousands of years previously. At present, surface water leaves the lower sump area only by evapotranspiration or by pumping to raise the water approximately 15 feet to its discharge point in the Klamath River.

The above description of the USBR Klamath Project is an oversimplification of an extremely complex system. The average figures for inflow and outflow mean little in attempts to evaluate the hydrology of the Lower Klamath Lake valley. Only the major canals and drains are gaged, and the patterns of irrigation use and drainage are not readily available for quantitative evaluation. In the absence of detailed data, only the crudest generalizations are possible regarding consumptive use, evapotranspiration, or recharge to the ground-water reservoir.

\section{OCCURRENCE AND MOVEMENT OF GROUND WATER}

\section{THE SHALLOW RESERVOIR}

The shallow ground-water reservoir in the Upper and Lower Klamath Lake valleys is, for the most part, a continuous, largely unconfined body to depths of more than 1,500 feet. Although few data are available in the highland areas, shallow cold ground water beneath the upraised rock masses also appears to be generally unconfined. Water levels in the valleys range from land surface to 10 or 15 feet below land surface, 
and annual fluctuations of the water table are generally less than 10 feet. Water levels in terrace deposits and alluvial fans are commonly 15 to 20 feet below land surface, whereas at places under the higher bedrock ridges the water table is as much as several hundred feet below the surface. Fluctuations of the water table in the highlands are probably even smaller than those observed in the valleys.

The generalized surface of the shallow nonthermal ground-water reservoir is shown on plate 1 . The water table appears to be a continuous, fairly smooth surface which forms a subdued replica of the topography. At numerous places, however, water levels in individual wells show departures from the smooth surface. As explained in the map text, some of these discrepancies result from errors of measurement or reporting. Many, however, reflect differences in geologic structure, stratigraphy, or well depth. Effects of ground-water pumping are believed to be negligible in most of the area.

Compartmentation of the shallow aquifer by faults undoubtedly occurs both in the valley sediments and the bedrock ridges. These discontinuities may account for water-level discrepancies such as those shown by wells on the southwest flank of the Klamath Hills and the edge of the hills near Keno. The effects are minor, however, throughout most of the volume of Pleistocene and Holocene sediments. Compartmentation that occurs at places in the Tertiary rocks is discussed below in the section on "Deeper Basaltic Aquifers."

Wells in the valley-fill deposits commonly show a decrease in static water level with depth; that is, the deeper wells have lower water levels. The lower water levels in deep wells are the result of partial confinement of the deeper zones of the aquifer and a loss of hydraulic head between the recharge areas and the aquifers tapped by the wells.

Hydraulic heads in wells are above land surface at several places in the area, indicating that the aquifer is confined at these places. Examples are wells north and east of Lake Ewauna (T38, R9, Sections 32 and 33), most wells north of Stukel Mountain (T39, R10, Sections 28-34), and some wells in Lost River valley south and west of Stukel Mountain. Many of these wells, particularly those north of Stukel Mountain, have large flows, but shut-in pressures indicate that artesian heads are generally less than 10 feet above land surface. In the southeastern part of Klamath Falls, hydraulic heads in some hot wells formerly were more than 20 feet above land surface (J. W. Lund, oral commun., 1976). In recent years, however, the heads have declined to near land surface, possibly as the result of increased use of water from hot wells in the Klamath Falls geothermal area.
Few artesian wells are more than about a mile from upraised fault blocks, and it is assumed that the recharge areas for all artesian wells are in the nearby ridges. Examination of drillers' logs generally suggests that the water is confined in permeable zones between basalt flows, or in granular sediments overlain by clay and silt of the lake deposits.

A few shallow artesian wells in the flood plain of the Lost River southeast of Klamath Falls (T39, R10, Sections 17-20) penetrate fine black sand that is overlain by silt and clay. Drillers' logs and data from a U.S. Geological Survey test hole indicate that the sand may be hydraulically connected to recharge areas in Hogback Mountain through permeable deltaic or fan deposits which form a ridge extending southward from the mountain. The relatively high water levels in this ridge are apparent on plate 1.

Logs of wells in the area suggest that the permeable deposits just described are also connected to the permeable terrace deposits on the north face of Stukel Mountain, as well as to subsurface stream gravels fanning out from Olene Gap. If so, the hot-water areas of Hogback Mountain, Stukel Mountain, and Olene Gap may be hydraulically connected through the valley sediments in a zone that extends to depths of 1,000 feet or more.

Springs are not abundant in the Klamath Falls area, and most springs appear to have no connection with hotter water at depth. The 15 springs shown on plate 1 constitute nearly all the identifiable perennial springs that issue at land surface. Additional springs issue from the bottom of Upper Klamath Lake, Spring Lake, Nuss Lake, and probably other small ponds, but these have not been separately identified on the map.

Most springs in the area produce cold water that is supplied by gravity flow from precipitation on adjacent recharge areas. Examples are Hummingbird, Shell Rock, Barkley, and Neubert Springs north of Klamath Falls, and an unnamed spring in the southwestern part of the area (T41, R8, Section $5 \mathrm{cbb}$ ), all of which issue from basalt rocks near the base of fault scarps. Eagle Point Spring and two springs in Olene Gap are warm artesian springs whose waters are partly derived from the geothermal reservoir. Temperatures of thermal. springs in Upper Klamath Lake are not known but are assumed to be fairly low. Springs with temperatures near the boiling point formerly issued along the base of the slope below the hot-well area of Klamath Falls, but flows from these springs gradually diminished during the past several decades and the springs no longer exist.

The general absence of springs on the flanks of upraised fault blocks confirms other evidence that water tables are relatively deep beneath the surfaces of 
these blocks. Seeps occur following precipitation on the mountains, but these are mostly short lived and the ground water is only temporarily perched above them.

\section{DEEPER BASALTIC AQUIFERS}

A few deep wells located on ridges near Klamath Falls penetrate basaltic rocks of probable Tertiary age. Four such wells clustered at the north end of the city of Klamath Falls are among the deeper hot-water wells in the area. A diagram showing profiles of these wells, along with three nearby cooler wells (fig. 4), suggests possible relations to faults and illustrates the compartmentation of the basaltic aquifers at this location. As the diagram illustrates, static water levels in the hot wells are accordant with each other but are at depths ranging from 170 to 200 feet below static levels in the three cooler wells and about 100 feet below the average level of Upper Klamath Lake. The water level in well OIT 3 is anomalously high, suggesting the presence of a local source of recharge and a high degree of compartmentation at this site.

An aquifer test has shown that the four hot wells (left side of diagram, fig. 4) are hydraulically connected through permeable basalt rocks. (See section on "Hydraulic Properties of the Rocks.") Water levels in these wells, therefore, probably represent the hydraulic head in the local geothermal system, which is assumed, from chemical evidence, to be largely sealed off from the shallow cold water.

Similar relations apparently occur in the hot-well area of Klamath Falls, where water-level altitudes in most hot wells are also lower than water levels in nearby cool wells (Lund and others, 1974; J. W. Lund, oral commun., 1976). It is concluded, therefore, that hydraulic heads in the shallow bedrock aquifer are generally higher than those in the geothermal aquifer over an extensive area of the Klamath Falls thermal area, although local departures from this generalization may occur.

One additional well that penetrates deep Tertiary basaltic rocks was inventoried in the Klamath Falls area. This is a 1,305-foot well on the north flank of Hamaker Mountain (T40, R7, Section 11ccc). The well produces water at a temperature of $16^{\circ} \mathrm{C}$ from fractured basalt flows and fragmental interflow zones at depths between 1,260 and 1,288 feet below land surface, corresponding to altitudes of 3,600 to 3,572 feet above sea level. Static water level in the well was reported by the driller in 1959 to be 1,193 feet below land surface at an altitude of 3,670 feet above sea level. The reported water level is 400 feet lower than water levels in shallow wells that penetrate bedrock at locations 2 to 3 miles to the northeast.
The low static head in the well at Hamaker Mountain is probably due to compartmentation of the aquifers by parallel faults that follow the regional trend through the area. A major fault has been mapped as striking through Bear Valley, just northeast of the well (Murray Gardner, written commun., 1975). The fault block is downthrown to the southwest, and numerous faults west of the main fault also have downthrown blocks to the southwest. Thus, water levels may be stepped down toward the southwest in partly isolated compartments created by the faults.

Little information is available on aquifers in Tertiary basaltic rocks in the highlands immediately north and east of Klamath Falls. Tertiary rocks that occur outside the study area in the Sprague River, Swan Lake, Langell, Poe, and Yonna Valleys were described by Leonard and Harris (1974). Hydraulic characteristics of these rocks have been evaluated by Illian (1970), and they appear to be similar to those of the deeper basaltic rocks underlying the Klamath Falls area, as confirmed by the few data obtained in the present study.

\section{MOVEMENT AND DISCHARGE OF GROUND WATER}

The water-level contours on plate 1 show that ground water in shallow aquifers near Klamath Falls moves generally southward toward Tulelake in California. Some of the flow, perhaps on the order of 80,000 acre-ft per year, is intercepted by Lake Ewauna and the Klamath River, and leaves the basin as streamflow. Most of the remainder enters the closed basins of Lower Klamath Lake and the Tulelake sump.

On the flanks of the northwest-southeast trending fault blocks, water-table gradients are steep, ranging from about $0.027\left(140 \mathrm{ft} \mathrm{mi}^{-1}\right)$ on the southwest side of Stukel Mountain to about $0.038\left(200 \mathrm{ft} \mathrm{mi}^{-1}\right)$ west of Lake Ewauna. These gradients reflect the steep surface topography as well as apparently low vertical permeabilities within the fault blocks.

South of Altamont, the moderate gradient of about $29 \mathrm{ft} \mathrm{mi}^{-1}$ suggests that rather permeable rocks extend into the valley from the southern flank of Hogback Mountain. Lithologic descriptions in drillers' logs confirm this suggestion. Similar or even smaller gradients were observed along the northwest edge of the valley between Klamath Falls and Keno. These gradients indicate that ground water moves freely parallel to the regional structure.

In areas near the principal hot-water bearing faults, thermal waters may move upward, discharging both water and heat to the near-surface environment. In larger areas surrounding the faults, the flow of hot water appears to be predominantly lateral. One example is a region of several square miles bordering the 


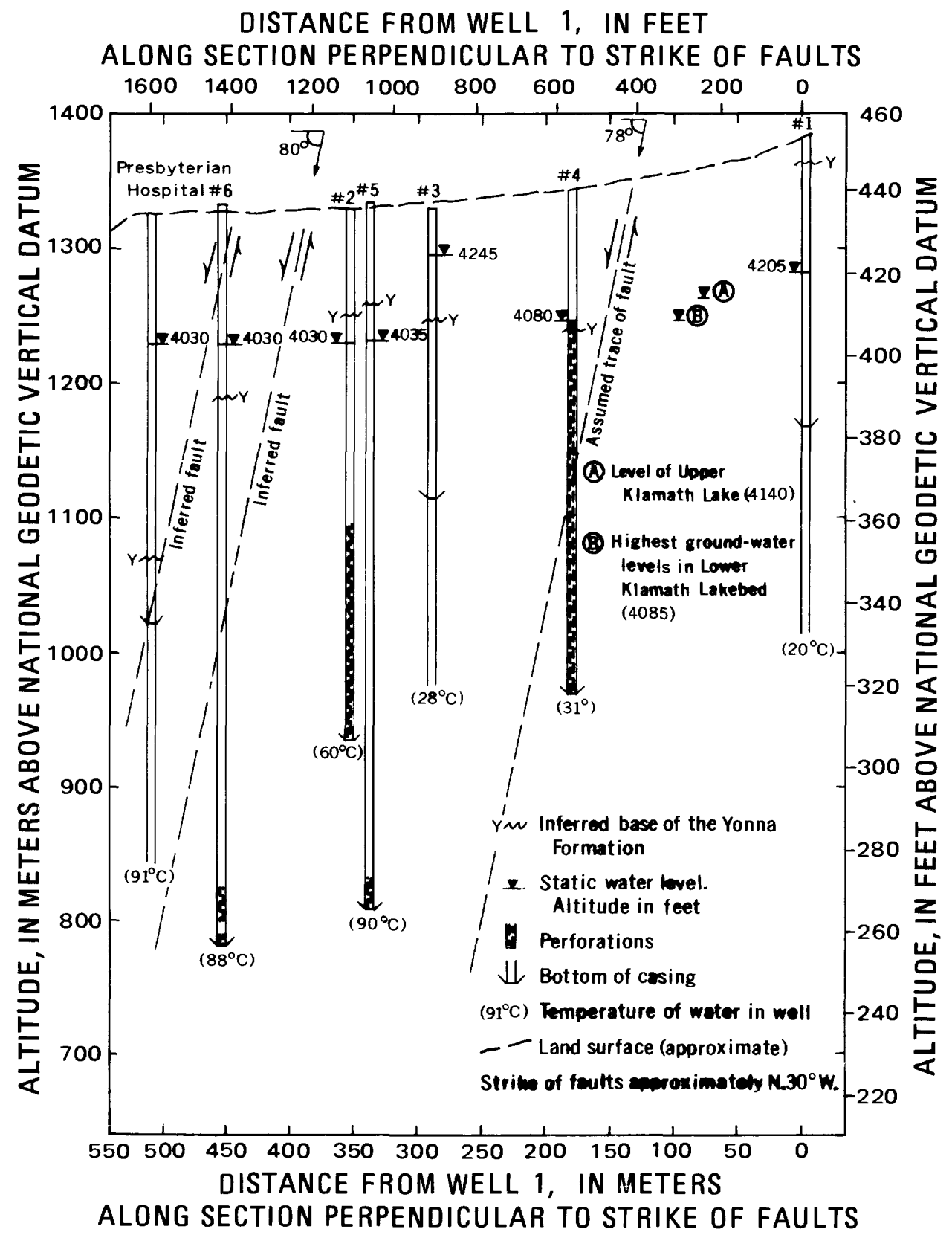

Figure 4.-Profiles of wells at the Oregon Institute of Technology and Presbyterian Intercommunity Hospital, showing discordant water levels and assumed relations to faults.

south edge of the city in which warm water from the hot-well area is believed to flow southward in permeable zones of layered basalt. Similar lateral flow may occur in the area west of the Klamath River and north of the Weyerhauser sawmill. The movement of thermal water is discussed further in the section on "Temperature Distribution and Heat Flow."

Large amounts of ground water probably move from one subbasin to another within the Upper Klamath River basin. Illian (1970, p. 55) estimates that 200,000 acre-ft per year enters the Lost River subbasin from the Upper Klamath Lake subbasin, and that 150,000 acre-ft per year enters from the Sprague River subbasin. Leonard and Harris (1974) conclude, however, that, although a significant amount of flow does occur, the available data do not permit an accurate quantitative evaluation of the interbasin movement.

A crude estimate of the amount of ground-water flow from the Upper Klamath lake basin into Lower Klamath Lake has been made on the basis of data from 
Illian and estimates derived from the present study. From data on wells penetrating Tertiary basaltic aquifers, Illian (1970, p. 13) calculated an average specific capacity of 145 gallons per minute per foot of drawdawn. A rough estimate of transmissivity may be obtained from values of specific capacity in efficient wells by multiplying gallons per minute per foot by 2000. On this basis, and converting to square feet per day, the transmissivity of the Tertiary basalt aquifers is estimated to be $40,000 \mathrm{ft}^{2} \mathrm{~d}^{-1}$. Assuming that flow occurs through a 20-mile section extending along the 4,100 foot water-level contour on plate 1 , and that the average gradient is $26 \mathrm{ft} \mathrm{mi}^{-1}$, the volume of groundwater flow into the Lower Klamath Lake basin is calculated to be about 175,000 acre-ft per year.

The estimated transmissivity, based on data from highly permeable basalt aquifers in subbasins north and east of Klamath Falls, may be an overestimate for the Klamath Falls area. A small amount of pumpingtest data from Klamath Falls suggests that the basalt aquifers underlying the city are less permeable than those in nearby basins. The assumed gradient is probably within 25 percent of the actual value for the upper 1,000 to 1,500 feet of the aquifer, but may be significantly higher than the actual gradient in a deep, regional flow system. The 20 -mile section is a maximum probable length. The estimate of groundwater flow, therefore, may be near the upper limit for the actual value.

A similar approach has been used to estimate ground-water flow out of the Lower Klamath Lake basin, but the uncertainties involved are much greater. Southwest of Klamath Falls, in the direction of the regional topograpic gradient, ground-water conditions in the closely-spaced parallel fault blocks are virtually unknown, and it is not possible to make realistic estimates of either transmissivities or gradients in this direction. The figure of 100,000 acre-ft per year used in the section on "Evapotranspiration" is, therefore, little more than a guess at a probable maximum groundwater flow from the basin.

Within the area studied for this report, ground water is discharged at land surface by pumping from wells, by artesian flow from wells and springs, and by seepage to the land surface or into lakes and streams. No attempt has been made to estimate the total discharge into lakes and streams, but rough estimates of the remainder of the ground-water discharge have been made. The results are shown in table 3 .

The total discharge to the land surface of ground water from springs and wells in the Klamath Falls area is estimated to be about $21 \mathrm{Mgal} \mathrm{d}^{-1}$, or about 22,000 acre-ft per year. This amount is an extremely small fraction of the water that enters the area either
TABLE 3.-Summary of ground-water discharge and use in the Klamath Falls area

\begin{tabular}{|c|c|c|}
\hline & $\begin{array}{c}\text { Discharge and } \\
\text { use } \\
\left(\mathrm{Mgal} \mathrm{d}^{-1}\right)\end{array}$ & $\begin{array}{c}\text { Percent of } \\
\text { total }\end{array}$ \\
\hline $\begin{array}{l}\text { Public Supply': } \\
\text { Klamath Falls, Altamont, } \\
\text { Merrill, and Falcon Heights } \\
\text { Irrigation } \\
\text { Industrial and commercial } \\
\text { Spring discharge } \\
\text { Space heating } \\
\text { Domestic (individual wells) } \\
\text { Stock watering } \\
\quad \text { Total }\end{array}$ & $\begin{array}{rr}-- & 7.3 \\
-- & 5.8 \\
-- & 3.0 \\
-- & 2.3 \\
-- & 1.9 \\
-- & .2 \\
- & 20.6\end{array}$ & $\begin{array}{r}35 \\
29 \\
14 \\
11 \\
9 \\
1 \\
<1\end{array}$ \\
\hline
\end{tabular}

'As of 1975 .

'Interpreted in part from data in Lund, (1978)

in streamflow or precipitation. (See section on "Climate and Drainage.")

\section{HYDRAULIC PROPERTIES OF THE ROCKS}

ESTIMATES FROM SPECIFIC CAPACITIES OF WELLS

The specific capacities of efficient wells afford crude estimates of the transmissivity of the aquifers penetrated by the wells. Specific capacity, expressed as yield in gallons per minute divided by the drawdown in feet, has been calculated from data provided by drillers and owners for about 170 wells in the Klamath Falls area. These data and estimated transmissivities derived from them are shown in table 4 . Because of widely differing well efficiencies and depths of aquifer penetration, estimates based on specific capacity are undoubtedly imprecise. They are used in this report solely for purposes of comparison.

In table 4, wells are assigned to one of several categories of rock type on the basis of drilling information. The rock types listed do not conform to the geologic units of Peterson and McIntyre (1970), but have been placed in generalized categories corresponding to commonly used terms in drillers' logs. The assignment of many wells to specific categories of wateryielding rocks is difficult, owing to uncertainties in drillers' logs or in geologic mapping, and the calculated numbers in table 4 thus contain some uncertainty. Where the number of wells is small, reassignment of one high-yielding well would make a large difference in the average specific capacity for the rock unit. The estimated transmissivities seem reasonable, however, in the light of reported yields of wells and observations of rock characteristics in outcrops.

The data of table 4 show that several types of rocks in the area provide similar low yields to wells. Wells in alluvial terraces, Holocene and Pleistocene lake deposits, "older" lake deposits, and rocks of volcanic eruptive centers have specific capacities in the narrow range 1.6 
TABLE 4.-Specific capacities of wells and estimates of transmissivity in aquifers of the Klamath Falls area

\begin{tabular}{|c|c|c|c|c|}
\hline $\begin{array}{l}\text { Water-yielding } \\
\text { rock unit }\end{array}$ & $\begin{array}{l}\text { Number } \\
\text { of wells }\end{array}$ & $\begin{array}{c}\text { Average } \\
\text { depth } \\
\text { (ft) }\end{array}$ & $\begin{array}{c}\text { Average } \\
\text { specific } \\
\text { capacity } \\
\text { (gal min } \\
\text { (git } \mathrm{ft}^{-1} \text { ) }\end{array}$ & $\begin{array}{l}\text { Estimated } \\
\text { transmissivity } \\
\text { of aquifer } \\
\left(\mathrm{ft}^{2} \mathrm{~d}^{-1}\right)\end{array}$ \\
\hline $\begin{array}{l}\text { Alluvial terrace } \\
\text { deposits. }\end{array}$ & 4 & 279 & 1.8 & 500 \\
\hline $\begin{array}{l}\text { Holocene and Pleis- } \\
\text { tocene lake deposits. }\end{array}$ & 24 & 194 & 1.6 & 400 \\
\hline $\begin{array}{l}\text { Rocks of Quaternary } \\
\text { basaltic flows. }\end{array}$ & 6 & 406 & 19 & 5,000 \\
\hline $\begin{array}{l}\text { Fragmental basaltic rocks of } \\
\text { Quaternary and } \\
\text { Tertiary eruptive centers. }\end{array}$ & of 27 & 187 & 2.1 & 600 \\
\hline $\begin{array}{l}\text { Older lake deposits } \\
\text { (Yonna Formation?) }\end{array}$ & 21 & 334 & 1.9 & 500 \\
\hline Yonna Formation & 70 & 450 & 29 & 8,000 \\
\hline $\begin{array}{l}\text { Rocks of Quaternary } \\
\text { and Tertiary basaltic } \\
\text { flows. }\end{array}$ & 18 & 869 & 37 & $10,000^{*}$ \\
\hline
\end{tabular}

*Aquifer tests at three sites yielded values ranging from 11,000 to $20,000 \mathrm{ft}^{2} \mathrm{~d}^{-1}$ at prevailing temperatures. (See text for temperature-corrected estimates.)

to $2.1 \mathrm{gal} \mathrm{min}^{-1} \mathrm{ft}^{-1}$. Although these rock types differ greatly in physical characteristics, it is not possible to distinguish one from the other on the basis of well performance.

The distinction between the categories "Rocks of Quaternary basaltic flows" and "Fragmental basaltic rocks of Quaternary and Tertiary eruptive centers" in table 4 is especially arbitrary because of disagreements among published maps and uncertainties in drillers' descriptions of the rocks. However, fragmental rocks of either Quaternary or Tertiary age appear to have similarly low permeabilities, whereas the basalt flows, regardless of age, are apparently much more permeable. As noted above, the permeable zones in the Yonna Formation are also associated with basalt flows.

Rocks labeled "Older lake deposits" in table 4 appear to be partly consolidated clay, silt, and diatomite deposits. These rocks have been identified only in drillers' logs and they are distinguished from rocks of the Yonna Formation primarily on the basis of their low transmissivities. Most wells identified as penetrating the Yonna Formation have fairly high transmissivities which are apparently due to the presence of basalt flows and breccias. Thus, the presence or absence of volcanic rocks may be the only significant feature that distinguishes the category "Yonna Formation" from "Older lake deposits" in table 4.

Drillers's logs indicate that the moderately high transmissivities in basaltic rocks of the Klamath Falls area are probably due largely to fractures rather than to permeable interflow zones such as occur elsewhere in many basaltic sequences. Few of the drillers' logs describe the exact nature of the water-bearing zones, however, and it is possible that "caving" or "soft lava" rocks referred to by the drillers represent scoriacious or vesicular tops of flows which may also be relatively permeable.

Two of the specific capacities listed in table 4 may be compared with those given by Illian (1970) for wells in the northern Klamath River basin. For wells in sedimentary aquifers, Illian reported an average specific capacity of $0.45 \mathrm{gal} \mathrm{min}^{-1} \mathrm{ft}^{-1}$, a value only about $1 / 4$ as great as the corresponding value in table 4. For the "Lower Basalt Aquifer," Illian reports an average specific capacity of $145 \mathrm{gal} \mathrm{min}^{-1} \mathrm{ft}^{-1}$ a value almost 4 times greater than the value for Quaternary and Tertiary basaltic rocks in table 4 . Although these discrepancies may represent real differences between aquifers, it seems more likely that they reflect statistical discrepancies resulting from small sample populations, uncertain geologic classifications, and error resulting from inefficient and partly-penetrating wells.

\section{ESTIMATES FROM PUMPING TESTS IN WELLS}

Estimates of transmissivity in Tertiary basaltic aquifers were derived from three pumping tests in the Klamath Falls area. The first test was conducted in 1956 by Robinson and Roberts, Ground-water Geologists, Tacoma, Wash., for the Weyerhaeuser Timber Company. The test was run in Weyerhaeuser well 4 (T39, R9, Section 8cbb) which is open in the lower basalt aquifer from 276 to 545 feet below land surface. Analysis by the writer of data from this test suggests that transmissivity of the aquifer at the Weyerhaeuser location is about $11,000 \mathrm{ft}^{2} \mathrm{~d}^{-1}$ at prevailing temperatures.

A second aquifer test was performed in 1974 by the U.S. Geological Survey, assisted by staff and maintenance personnel of the Oregon Institute of Technology. Three thermal wells penetrating Tertiary basaltic rocks were used for the test: well OIT 5 was pumped while observations of water levels were made in well OIT 6 and a well at Presbyterian Hospital (fig. 4). The three wells range in depth from 1,584 to 1,805 feet and had temperatures at the time of the test ranging from $88^{\circ}$ to $91^{\circ} \mathrm{C}$. The responses of the observation wells demonstrate that all three wells are hydraulically connected in a relatively permeable formation. The drawdown data provide a poor fit to type curves based on standard analytical models, but the general shapes of the curves and the magnitudes of the drawdowns suggest that the apparent transmissivity is about 22,000 $\mathrm{ft}^{2} \mathrm{~d}^{-1}$. A factor of approximately 0.3 should be applied to this value in order to reduce temperature, viscosity, and density to standard values for comparison with nonthermal aquifers. Thus, the actual transmissivity of the aquifer may be less than $7,000 \mathrm{ft}^{2} \mathrm{~d}^{-1}$ for an aquifer at $16^{\circ} \mathrm{C}$. 
A third pumping test was performed in 1976 by the staff of the Geo-Heat Utilization Center, OIT, in an artesian well at the County Museum, Klamath Falls. During this 28-hour test, water levels were measured in 12 nearby wells.

The Museum well, which is reportedly 1,234 feet deep, penetrates the Yonna Formation and underlying Tertiary basaltic rocks at a location near the southwestern limit of the main hot-well area of Klamath Falls. Observation wells for which data could be analyzed penetrate the Yonna Formation (including some basalt flows) at depths shallower than 500 feet. Water temperatures in the observation wells ranged from 56 to $85^{\circ} \mathrm{C}$. Distances from the pumped well to the 12 observation wells ranged from 123 to 1,425 feet.

Analysis of the drawdown data by the author shows that all the wells measured are hydraulically connected through rocks of the Yonna Formation and the underlying basalts. Apparent transmissivity is about $20,000 \mathrm{ft}^{2} \mathrm{~d}^{-1}$ at prevailing temperatures, although some of the less reliable data suggest that the value might be significantly higher. Converting to a standard temperature of $16^{\circ} \mathrm{C}$, transmissivity is estimated to be about $10,000 \mathrm{ft}^{2} \mathrm{~d}^{-1}$.

The storage coefficient of the aquifer, a dimensionless number that expresses the volume of water released from, or taken into, the aquifer per unit surface area per unit change of head, was also estimated from the drawdown data. The storage coefficient is probably in the range 0.001 to 0.01 .

Estimates of transmissivity derived from the three aquifer tests are close to the average value calculated from specific capacities in 18 wells (table 4 ). The data indicate, therefore, that the average transmissivity of shallow Tertiary basaltic aquifers in the vicinity of Klamath Falls is moderately high (about $10,000 \mathrm{ft}^{2}$ $\mathrm{d}^{-1}$ ), but is significantly lower than that calculated for Tertiary basaltic aquifers in adjacent basins (Illian, 1970 , p. 13). Estimates from both thermal and nonthermal wells at Klamath Falls are similar, indicating that for depths less than about 1,500 feet, no distinction can be made between thermal and nonthermal aquifers on the basis of well performance.

\section{CHEMISTRY OF GROUND WATER}

\section{GENERAL CHEMICAL CHARACTERISTICS}

Ground water of the Klamath Falls area has generally low concentrations of dissolved-solids and is of good quality for most uses. The thermal waters are of poorer quality, although concentrations of dissolved solids in the hotter waters, estimated from specific electrical conductance, are generally no greater than
1,000 milligrams per liter ( $\left.\mathrm{mg} \mathrm{L}^{-1}\right)$. Both thermal and nonthermal waters have $\mathrm{pH}$ in the range 7.5 to 8.5 and are, therefore, mildly alkaline.

Chemical analyses of water from 59 wells and springs in the vicinity of Klamath Falls are listed in table 5. Differences in the quality of ground water in the area are shown by contours on the values of specific electrical conductance on plate 2 . The chemical character of the water is indicated on plate 2 by Stiff diagrams, and the dominant chemical characteristics are shown in a diagram of percent reacting values of major cations and anions (fig. 5).

In figure 5, the open circles represent cold, dilute waters of the area. These samples are typical of cold water derived from basaltic rocks and shallow volcanic sediments. Temperatures of these samples range from $10^{\circ}$ to $14^{\circ} \mathrm{C}$. The crosses in figure 5 represent hot waters, nearly all of which issue from basaltic rocks and associated volcanic sediments. Temperatures of hot water sampled in this study ranged from $61^{\circ}$ to $93^{\circ} \mathrm{C}$. Solid circles in figure 5 represent samples collected from 25 of the hundreds of warm wells and three warm springs scattered throughout the area. These waters, produced mostly from the Yonna Formation and alluvial and lacustrine deposits, appear to be mixtures of recent metoric water and warm water of deeper circulation. Temperatures of these samples ranged from $15^{\circ}$ to $37^{\circ} \mathrm{C}$. Waters in this category are referred to in this report as transitional waters. A fourth category, warm waters from the Klamath Hills, comprises transitional waters whose chemical characteristics differ greatly from other warm waters of the area. These waters are discussed in following sections of this report.

The principal ionic constituents of the cold waters are calcium, magnesium, and bicarbonate (figure 5). Concentrations of dissolved solids are generally low, and specific electrical conductance in the waters sampled ranged from 110 to $430 \mu \mathrm{mho} \mathrm{cm}^{-1}$.

The transitional waters are also predominantly calcium-magnesium-bicarbonate waters which, as shown in figure 5 , contain greater amounts of sodium plus potassium than the six cold waters. In actuality, this increase is due almost entirely to higher concentrations of sodium. The trend of increasing sodium corresponds generally to increasing temperature in the transitional waters. It is apparent in figure 5 that there is no corresponding increase in sulfate and chloride in the transitional waters as would be expected in a simple mixing trend between cold and hot waters.

The hot waters shown in figure 5 are clearly distinguishable from both cold and transitional waters. Their positions on the graph reflect greatly increased concentrations of sodium, sulfate, and chloride relative to the cold waters. The samples of hot water obtained 

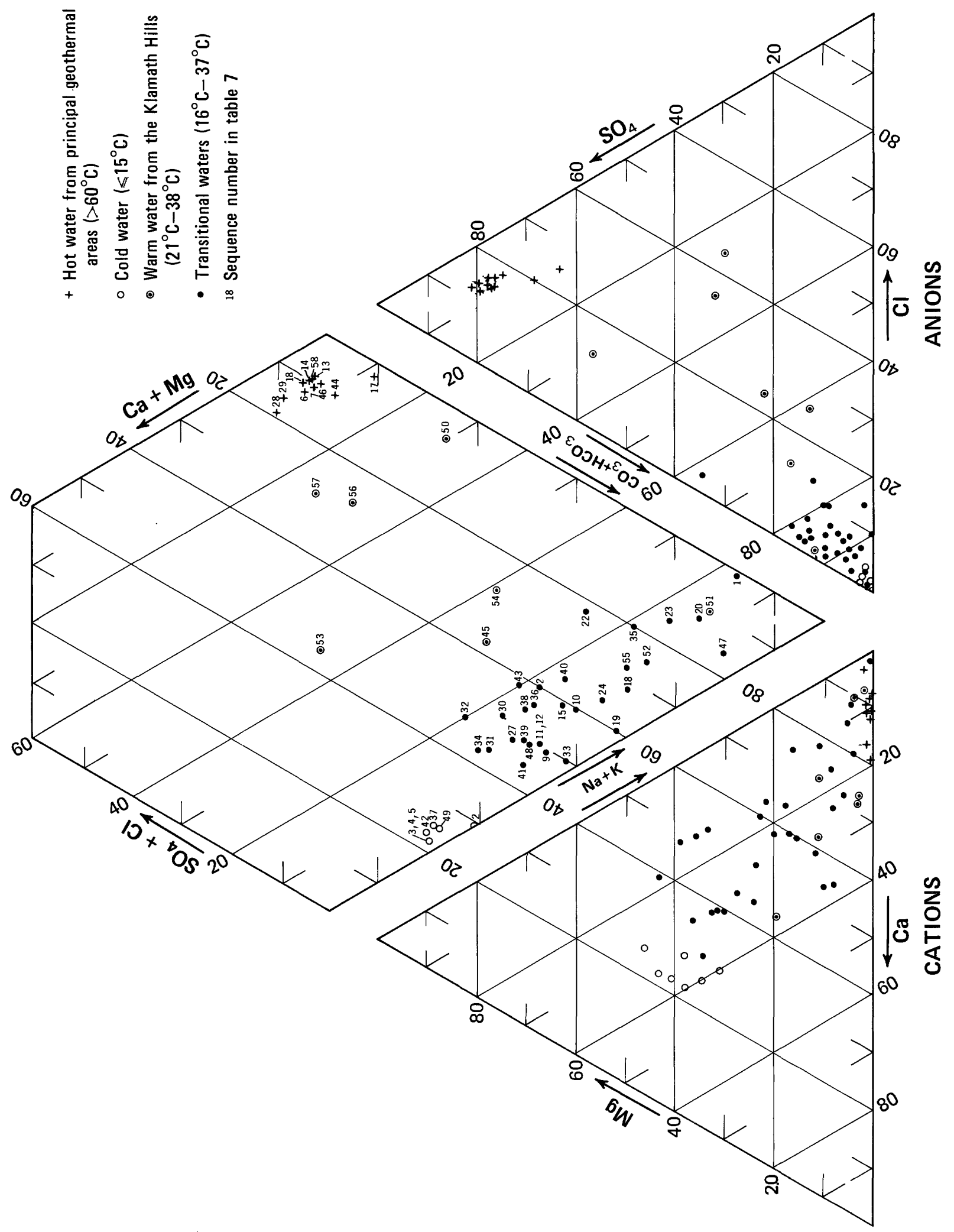


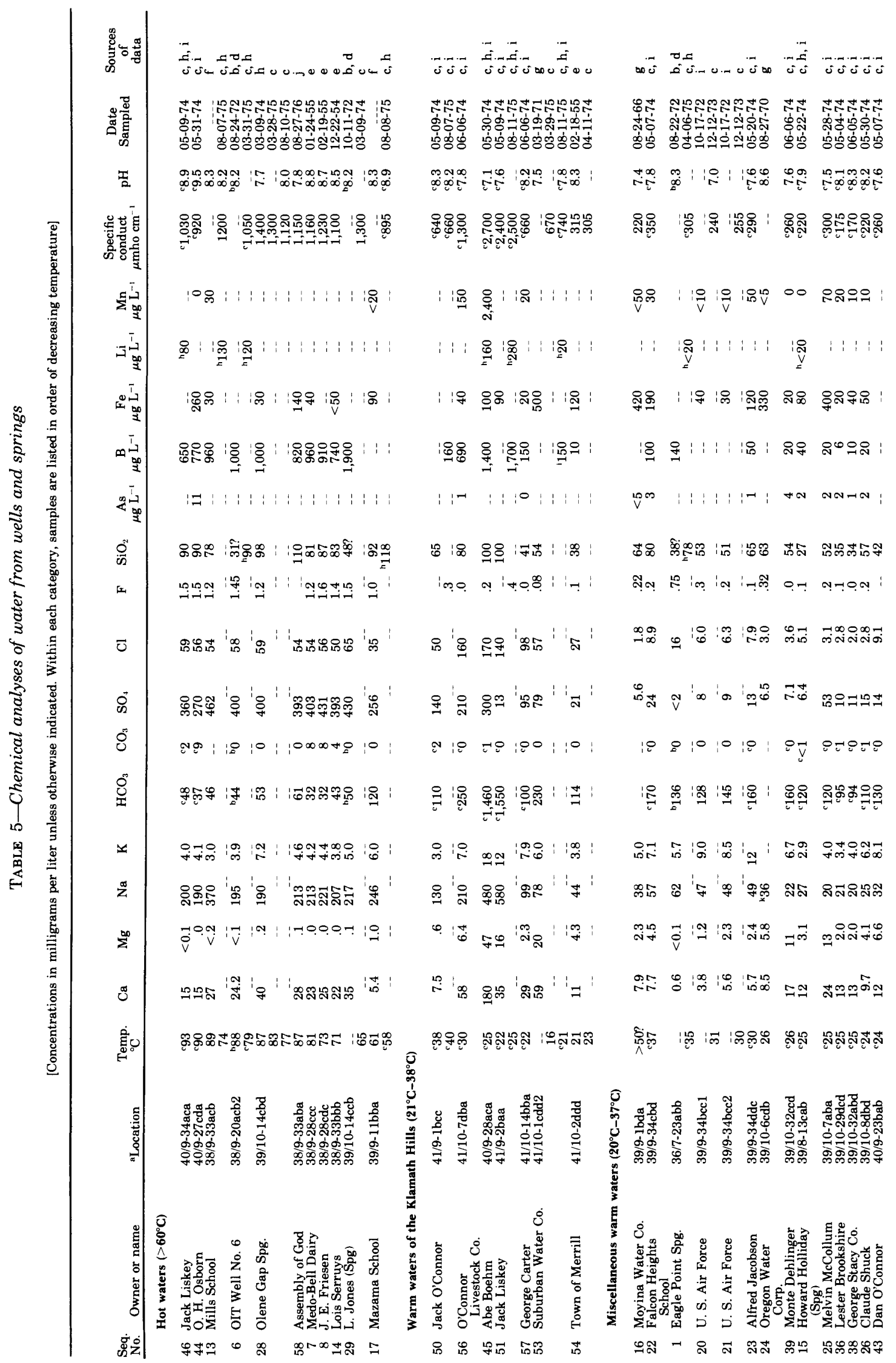




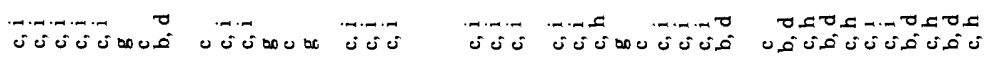

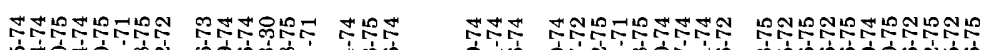

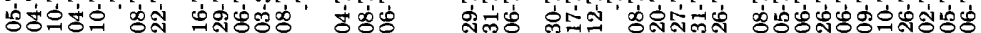

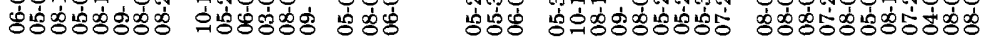

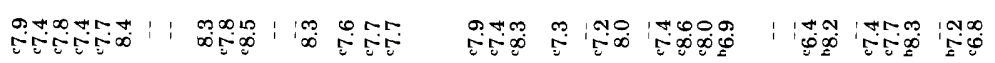

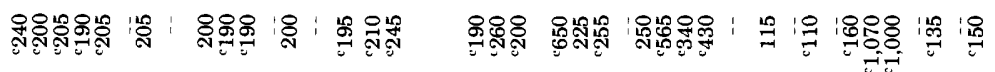

ㅇ: $1: \operatorname{lo}:$ :

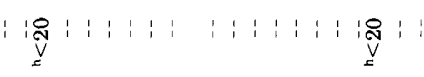

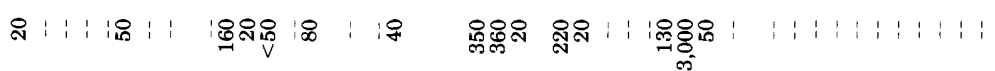

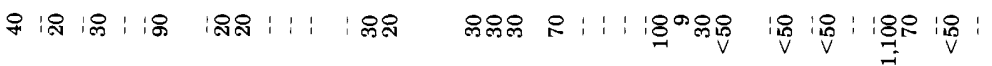

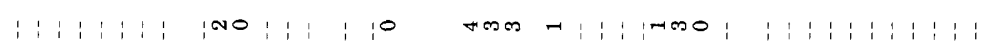

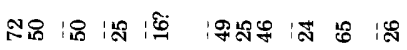

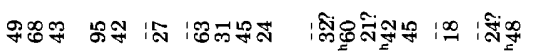

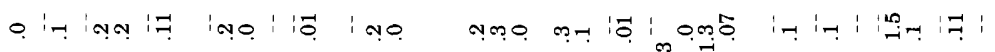

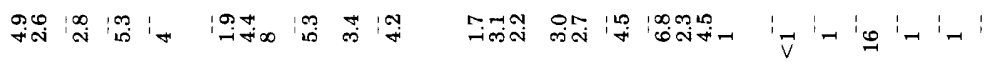

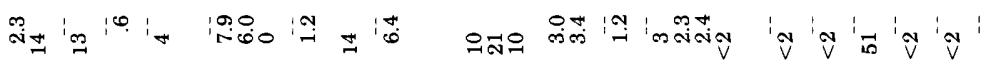

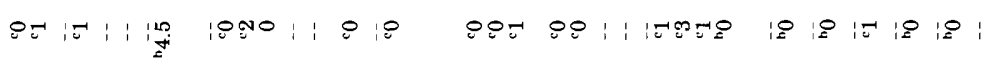

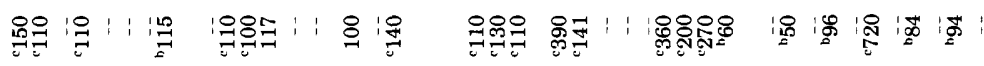

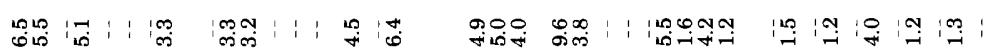

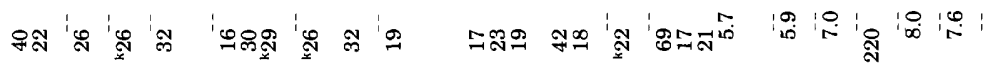

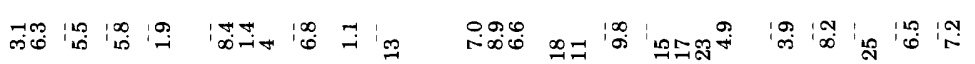
வ

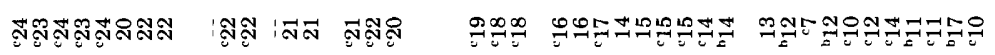

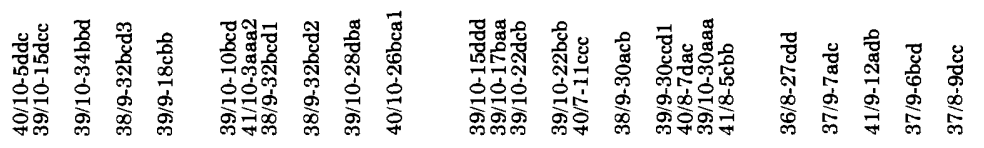
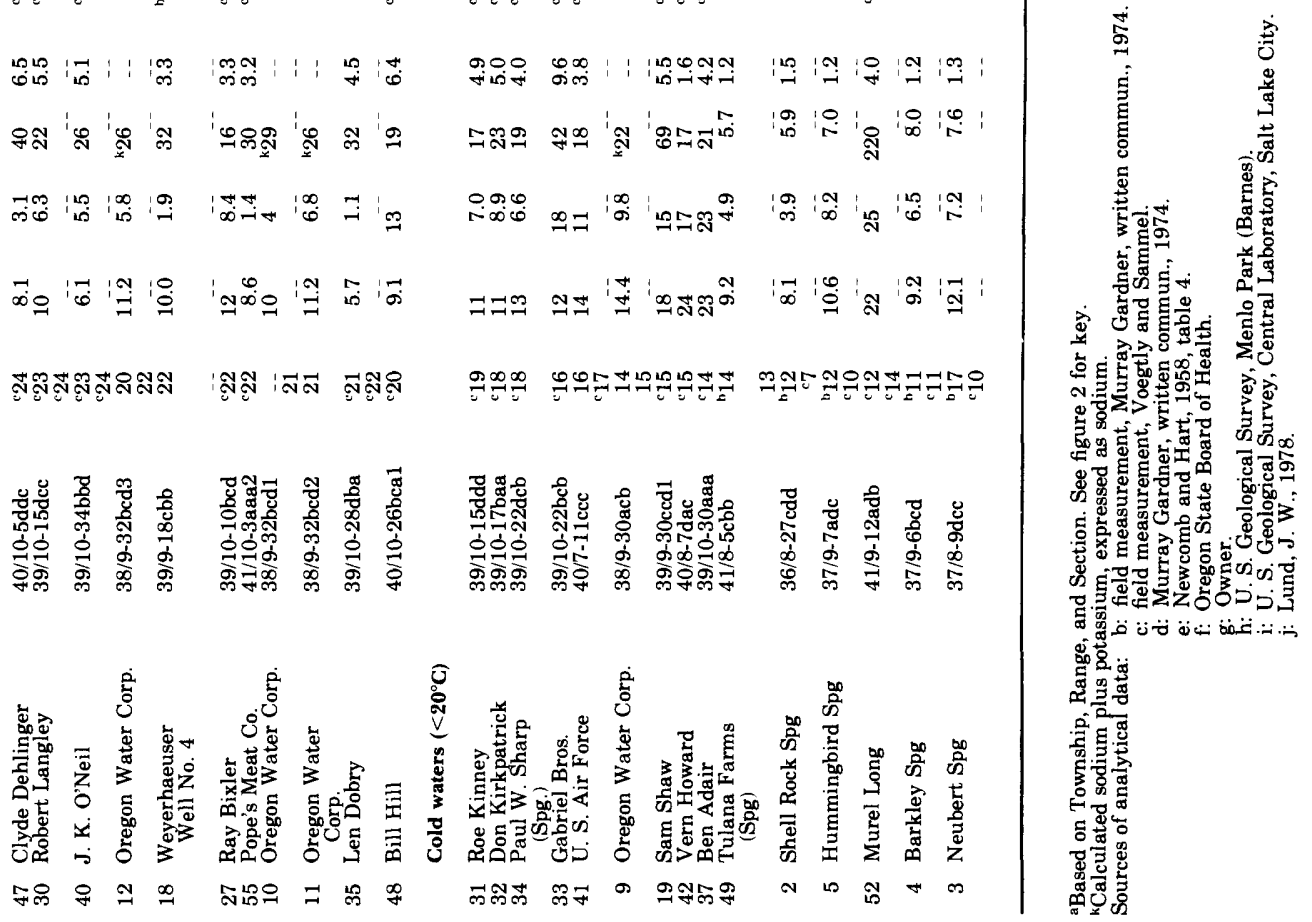
for this study are typical of water in the more than 400 hot wells used for space heating in Klamath Falls (Lund, 1978) as well as hot water from Olene Gap and the Klamath Hills.

In two areas of the lower Klamath Lake valley, ground water occuring at depths of 1,000 feet or more has generally high values of specific electrical conductance and is, for the most part, unfit for drinking. These areas are delimited on plate 2 by two 1,000 $\mu$ mho contours located north and south of Miller Hill. No chemical analyses are available from these areas, but owners' reports and field observations indicate that much of the water contains large amounts of iron, sulfate, and methane gas, as well as traces of hydrogen sulfide gas. Temperatures of water in the northernmost area are generally higher than normal. Drillers' logs indicate that the water is contained in fine-grained, organic-rich sediments depleted in oxygen. These parts of the basin quite possibly were marshy sumps and areas of evaporative ground-water discharge during long periods of late Pleistocene and Holocene time.

\section{RELATIONS AMONG DISSOLVED CONSTITUENTS}

Concentrations of dissolved constituents in ground waters of the Klamath Falls area differ widely, depending on the lithology of the aquifer, the temperature of equilibration, and the amount of mixing that has occurred between thermal and nonthermal waters. Some of these relations are discussed in this section of the report. The relations of common cations and silica to temperature are discussed more fully in a separate section below.

Cold ground water derived from shallow alluvium and basaltic rocks in the Klamath Falls area is a calcium-magnesium bicarbonate water which originates in local precipitation and acquires small concentrations of dissolved solids mainly by solution of feldspars and other silicate minerals in the volcanic rocks. Silica concentrations are relatively high, commonly as great as 40 to 50 milligrams per liter, indicating that even in basaltic rocks abundant silica is available for solution.

The chemical character of water in the basaltic rocks does not change significantly even after penetration to great depths. For example, water obtained at a depth of about 1,300 feet in a well on the northeast flank of Hamaker Mountain (sample number 49, table 5 and pl. 2) has acquired slightly increased concentrations of dissolved solids relative to meteoric water but is not greatly different in quality from waters that presumably have penetrated less than a few hundred feet before emerging at the surface in gravity springs (samples 2 , 3,4 , and 5 ).
Hot waters from the three principal geothermal areas are represented by 10 samples having temperatures greater than $65^{\circ} \mathrm{C}$. An additional sample, number 17 , with a temperature of $61^{\circ} \mathrm{C}$, plots below the main group in the diagram of figure 5 but is sufficiently similar to warrant inclusion with the hot waters in most of the discussions below.

The hot waters are obtained from wells and springs that tap both the Yonna Formation and underlying basaltic rocks. These waters probably originate in local precipitation. If this supposition is true, the meteoric waters, in their passage through the geothermal reservoir, acquire increased amounts of calcium, sodium, potassium, chloride, sulfate, and silica, while concentrations of bicarbonate decrease somewhat and magnesium is reduced almost to zero. Changes of this kind are commonly found in hot-water geothermal systems (White, 1970), and they are compatible with the assumption that the Klamath Falls thermal waters are locally derived.

In hot waters from the principal geothermal areas, concentrations of major ions generally differ more widely among samples from the same area than among the three areas. Ratios of the major ions in hot waters show no consistent differences from one geothermal area to another. Some of the ratios that are of particular interest in geothermal waters are given in table 6 .

Molal ratios of $\mathrm{Ca} / \mathrm{Mg}, \mathrm{Na} / \mathrm{Ca}$, and $\mathrm{Na} / \mathrm{K}$ are significantly higher in the hot waters than in the cold waters and ratios of $\mathrm{Na} / \mathrm{Cl}$ and $\mathrm{Ca} / \mathrm{Cl}$ are lower. High ratios of calcium to magnesium are generally characteristic of high-temperature geothermal systems, but may occur at temperatures as low as $100^{\circ} \mathrm{C}$ (White, 1970 , p. 70 ). High ratios of sodium to potassium also imply elevated reservoir temperatures, but suggest that the waters equilibrated at temperatures not much higher than the measured temperatures (Mariner and Willey, 1976; White, 1970). Ratios of $\mathrm{Na} / \mathrm{K}$ are strongly influenced by the amount of available calcium in the water and cannot be relied upon as geothermometers in waters, such as those at Klamath Falls, for which molal ratios of $\sqrt{\mathrm{Ca}} / \mathrm{Na}$ are greater than one and indicated reservoir temperatures are low (Fournier and Truesdell, 1973, p. 1272).

Molal ratios of $\mathrm{Ca} / \mathrm{HCO}_{3}$ are low in the cold waters (range 0.04 to 0.2 ) and increase, as would be expected, in typical hot waters (range 0.5 to 1.2). The values of this ratio in the thermal waters are not high enough, however, to suggest that the waters equilibrated at extremely high reservoir temperatures (White, 1970, p. 69).

Ratios of total carbon species (mainly $\mathrm{HCO}_{3}$ and $\mathrm{CO}_{3}$ ) to chloride are low in the hot waters and these ratios clearly distinguish the hot waters from waters of lower 
TABLE 6.-Ratios of dissolved constituents in ground water

[Molal ratios except where weight ratio is indicated]

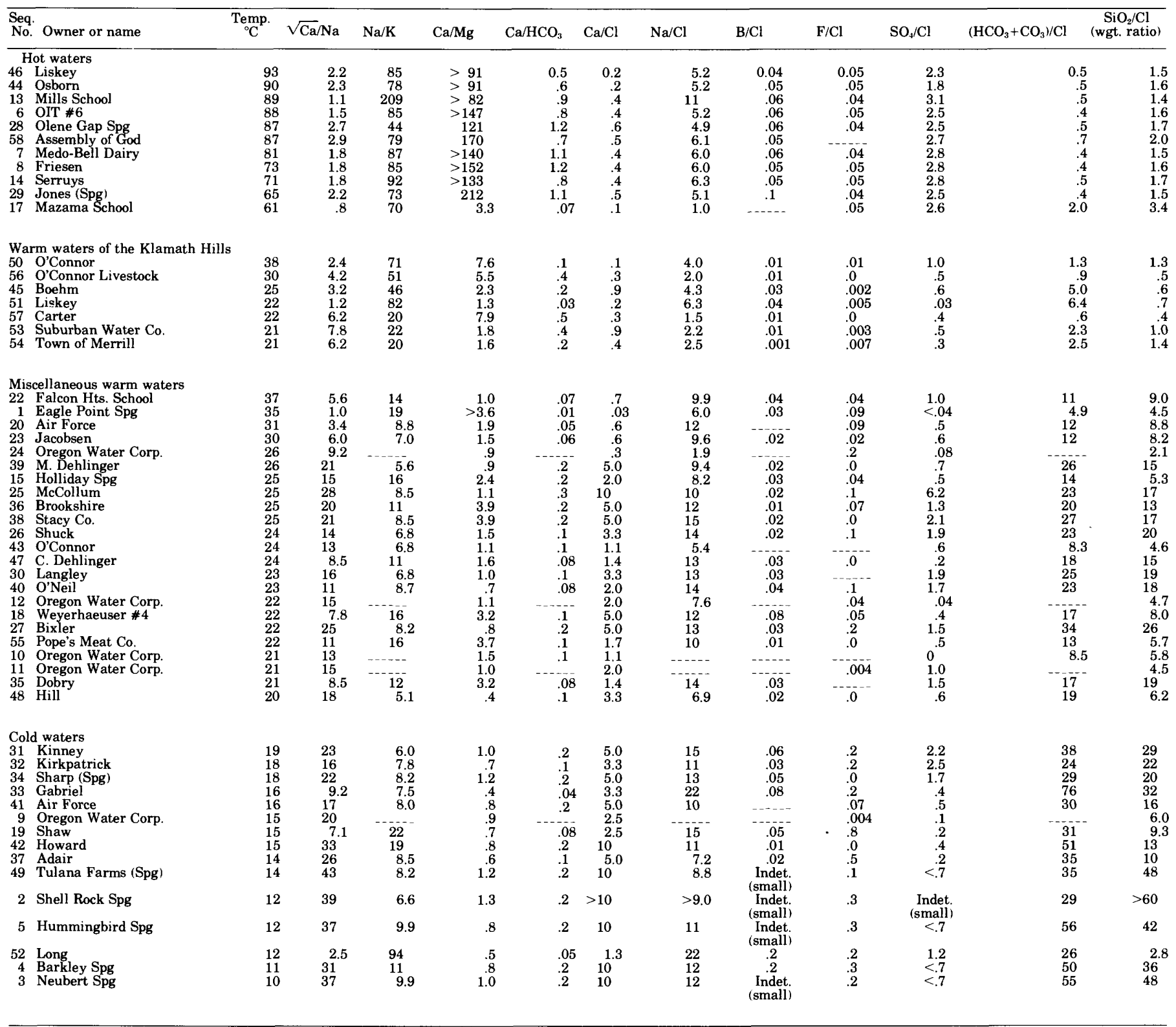

temperature. Cold waters have uniformly high ratios, and transitional warm waters have ratios that are generally similar to or slightly lower than those of the cold waters. Ratios of total carbon to chloride show no significant differences in 10 of the 11 hot waters despite temperature differences of almost $30^{\circ} \mathrm{C}$ among these waters, whereas in nonthermal and mixed waters in which temperature differences are also about $30^{\circ} \mathrm{C}$, ratios of total carbon to chloride differ by an order of magnitude.

The nearly constant ratios of carbonate species to chloride in hot waters of greatly differing temperature suggest that the temperature differences in these waters are due to conductive heat loss rather than mixing with cooler waters. The apparent lack of mixing in the hot waters implies, therefore, that these waters rise through conduits that are largely isolated from the shallow ground-water reservoirs of the area. It seems clear that most of these conduits occur in the major fault zones of the principal thermal areas. The widespread occurrence of warm water in the lower Klamath Lake basin suggests, however, that significant amounts of thermal water also arise from undiscovered faults underlying the valley floor. 
Ratios of $\mathrm{SO}_{4} / \mathrm{Cl}$ are slightly higher in the hot waters than in the cold waters, suggesting that the deeply circulating thermal waters are enriched in sulfate, either through contact with gypsum deposits or by oxidation of hydrogen sulfide gas which is known to be present in the hotter waters of the area (J. W. Lund, oral commun., 1975; Peterson and Groh, 1967).

The increased $\mathrm{SO}_{4} / \mathrm{Cl}$ ratios in the hot waters have been interpreted as suggesting that a steam reservoir underlies the Klamath Falls graben (Murray Gardner, written commun., 1975; Peterson and Groh, 1967). The interpretation is based on the possibility that hydrogen sulfide gas rising from a deep steam reservoir may be oxidized to the sulfate as it enters shallower aquifers thereby increasing the ratio of $\mathrm{SO}_{4}$ to the nonvolatile chloride. If this hypothesis is correct, volatile constituents such as boron (B) and fluoride (F) might also be expected to be transported in the vapor from the underlying steam reservoir, thereby increasing the ratios of these elements to chloride in the thermal waters (Truesdell, 1976a). In the samples obtained for this study, however, the ratios of fluoride to chloride are smaller in the thermal waters than in the cold waters, and ratios of boron to chloride in the thermal waters are similar to those in the five cold water samples. Thus, although these ratios are somewhat unreliable owing to the small concentrations of the three constituents in the cold waters, they provide no support for the theory of an underlying steam reservoir.

Most of the warm transitional waters in the lower Klamath Lake valley have temperatures in the range $20^{\circ}$ to $40^{\circ} \mathrm{C}$. These waters are produced by wells, generally no more than 500 feet deep, that penetrate alluvial and lacustrine deposits and interbedded basaltic rocks of the Yonna Formation. The unconsolidated deposits include diatomaceous earths, mixed-layer clay-mineral assemblages, kaolinite, feldspathic and organic-rich silt, fine siliceous sand with large percentages of volcanic glass and mafic materials, and coarser-grained sand and gravel also derived from volcanic rocks. A few wells and three warm springs probably derive water almost entirely from volcanic rocks and breccias of basaltic composition. These diverse sources of warm water are represented by 25 samples which show, as expected, wide variations in chemical composition.

Log molal ratios of several major ions in cold, transitional, and hot waters are shown graphically in figure 6 . The ratios selected are those that best illustrate the diversity of the transitional waters and the trends, or absence of trends, between the hot and cold waters. These ratios do not coincide with those selected for table 6. In each graph, samples are arranged from left to right in order of increasing chloride concentra- tion. This also turns out to be the general order of increasing sodium concentration and increasing temperature. For reasons discussed below, warm waters from the Klamath Hills area are placed in a separate group.

If the logical assumption is made that higher temperatures in the transitional waters result from larger amounts of thermal waters mixing with local meteoric waters, it would be expected that ratios of sodium to chloride, which do not differ greatly between the cold and hot waters, would remain fairly constant as temperatures increase. However, other ratios, such as sodium to calcium, calcium to magnesium, and total carbonate to chloride, which differ greatly between cold and hot waters, should show trends toward their values in the hot waters. The data of figure 6 show these expected trends in the sequence of transitional waters and thus tend to support the assumption that, in general, the warm waters in the Klamath Falls area represent varying mixtures of thermal and meteoric waters. The trends in sodium/calcium, calcium/ magnesium, and total carbonate/chloride ratios are fairly distinct, despite effects of local lithology which are the probable cause of significant departures from the trends in individual waters.

Concentrations of silica are extremely variable in the warm waters (table 5) and ratios of this constituent to other major ions (not shown in figure 6) have little correlation with temperature trends. A graph of $\log$ molal silica concentrations in ground water (figure 7A) demonstrates the variability of silica concentrations in cold and transitional waters in relation to the trend of increasing chloride concentration shown in figure $6 \mathrm{H}$. It can be seen in figure 7A that the variability of silica in five of the coldest and most dilute waters is greater than the variability in 10 hot waters from the principal geothermal areas. The relation of silica concentration is shown explicitly in figure $7 \mathrm{~B}$, where two trends are indicated for Klamath Hills warm waters and the hot waters. The suggested trend, A, between cold and hot waters is not supported by any field evidence, however, and the silica concentrations in both groups appear to be largely independent of the chloride concentrations.

The relation of chloride concentration to temperature might be expected to define mixing trends in the warm waters if such trends exist. As shown in figure $7 \mathrm{C}$, however, the trends are not well defined and the relation does not show a high degree of correlation. It is not surprising, therefore, that silica concentrations show an even poorer correlation with temperature (figure 7D) and fail to suggest any clear trends.

The wide scatter in the concentrations of the various ions and the consequent scatter in plots of ionic ratios indicate the difficulties that may be encountered in attempts to apply chemical geothermometry to low- 

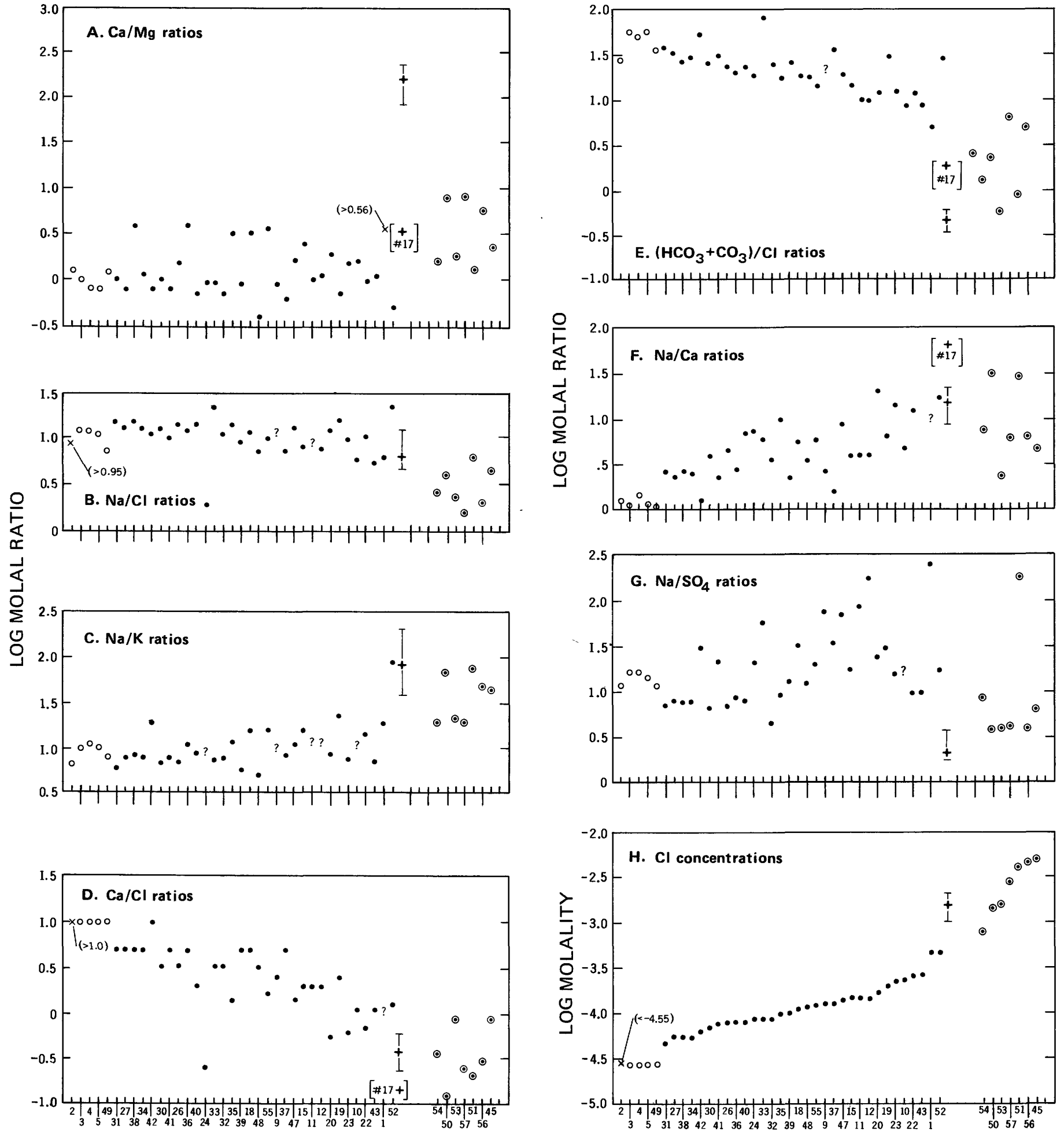

\section{SAMPLES, IN ORDER OF INCREASING CHLORIDE CONCENTRATION \\ EXPLANATION}

I Median value and range of values for 11 hot waters $\left(>60^{\circ} \mathrm{C}\right)$. When sample 17 is shown separately, median and range are for remaining 10 samples $\left[\begin{array}{c}+ \\ \# 17\end{array}\right] \begin{aligned} & \text { Hot water sample } 17 \text {; shown when ratio differs significantly } \\ & \text { from other hot waters }\end{aligned}$
- Warm water from the Klamath Hills

- Warm transitional (mixed) water

- Cold water $\left(<15^{\circ} \mathrm{C}\right)$ derived from basaltic rocks

$\times$ Value greater or less than number in parentheses

FIGURE 6.-Log molal ratios of dissolved constituents in ground waters arranged in order of increasing chloride concentration. 

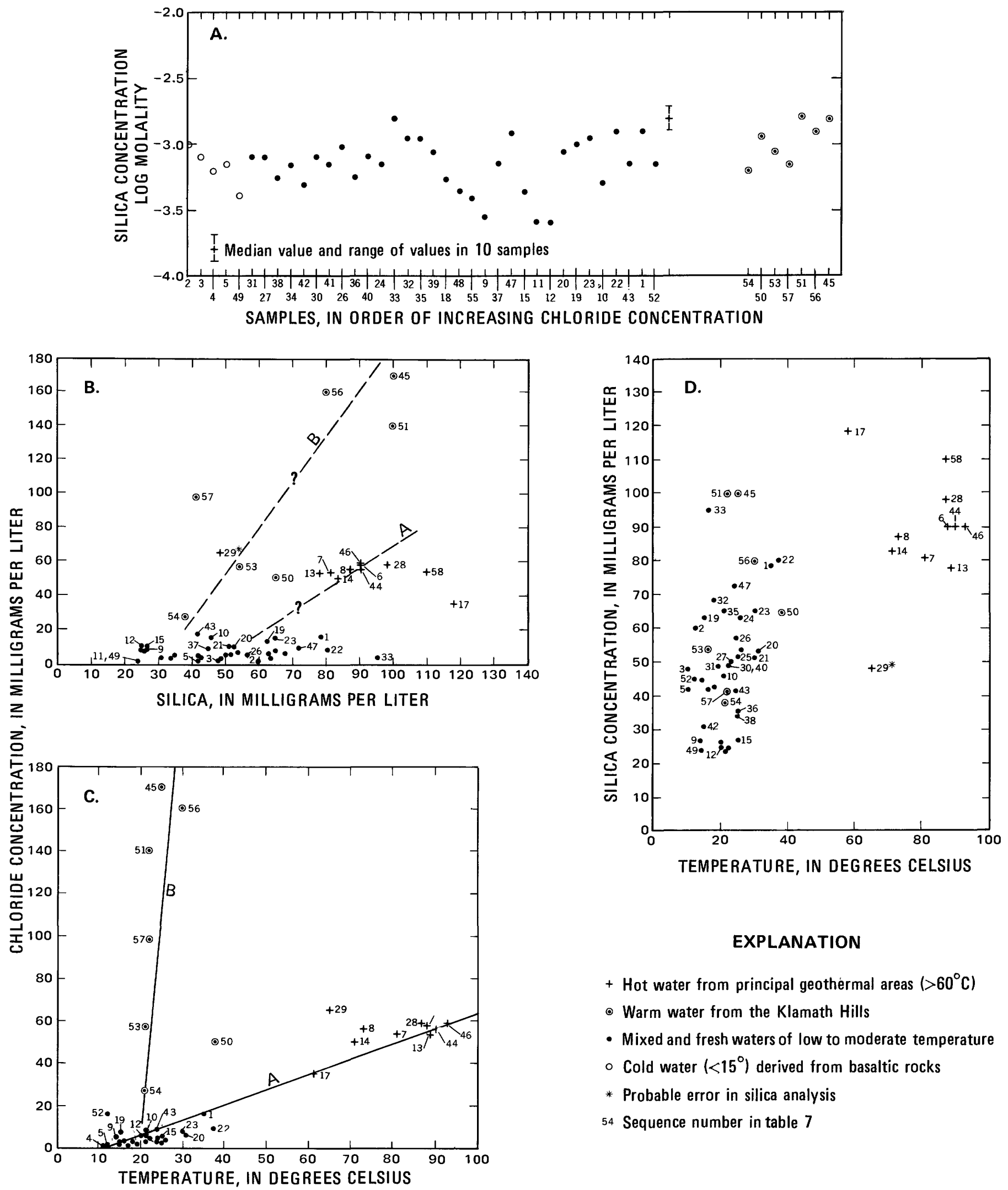

\section{EXPLANATION}

+ Hot water from principal geothermal areas $\left(>60^{\circ} \mathrm{C}\right)$

- Warm water from the Klamath Hills

- Mixed and fresh waters of low to moderate temperature

- Cold water $\left(<15^{\circ}\right)$ derived from basaltic rocks

* Probable error in silica analysis

54 Sequence number in table 7

FIGURE 7.-Silica and chloride concentrations in ground water and their relations to observed water temperature. A. Log molal $\mathrm{SiO}_{2}$ concentrations in samples arranged in order of increasing chloride concentration. B. Chloride versus silica concentration, showing separate trends for warm waters of the Klamath Hills (line B) and hot waters from the principal geothermal areas (line A). C. Chloride concentration versus temperature, showing two possible dilution trends (lines A and B). D. Silica concentration versus temperature. 
temperature waters from volcanic terranes. (See the section on "Reservoir Temperatures Estimated from Chemical Geothermometers.") It is clear that both silica and cation geothermometers may be unreliable in these settings and should be applied to lowtemperature waters only when most of the chemical relations indicate that the waters have cooled conductively or are simple mixtures of thermal and regional background waters.

A group of seven samples obtained from warm wells in the vicinity of the Klamath Hills thermal area are chemically anomalous with respect to other warm waters of the region. (See tables 5 and 6.) Despite the relatively low temperatures of these waters (maximum $38^{\circ} \mathrm{C}$ ), concentrations of sodium, calcium, sulfate, chloride, and silica are among the highest encountered in the area, and electrical conductances are generally high, ranging from 640 to $2,700 \mu \mathrm{mho} \mathrm{cm}^{-1}$ in six of the seven samples.

The distinctive chemical character of the Klamath Hills warm waters is shown by the graphs of ionic ratios in figure 6 and by graphs of chloride concentration versus temperature (fig. $7 \mathrm{C}$ ). The chloride concentrations in figure $7 \mathrm{C}$ form a trend for the Klamath Hills warm waters (line B) that differs greatly from the trend inferred for the hot waters (line A). Graphs of other ions, notably sodium and sulfate, versus temperature (not included in this report) also show distinctive trends similar to line B. These data are consistent with the isotope compositions (discussed in a subsequent section of this report) in suggesting a separate origin or history for warm waters of the Klamath Hills area.

The cause of the anomalous chemical characteristics in the Klamath Hills warm waters is uncertain, but the isotopic compositions strongly suggest that these characteristics are the result of low-temperature evaporation of the hot waters of the area. If so, the characteristics of these waters may be genetically related to their occurrence in the closed basin of Lower Klamath Lake.

\section{RESERVOIR TEMPERATURES ESTIMATED FROM CHEMICAL GEOTHERMOMETERS}

Because the solubility of silica in water of less than $\mathrm{pH} 9$ is affected only by the temperature of the water, silica concentrations in thermal waters have been used as a basis for estimating reservoir temperatures (Fournier and Row, 1966). The estimates of reservoir temperature are based on the following assumptions: (1) Silica is freely available in the reservoir rocks; (2) the water has remained in contact with the rocks for a sufficient length of time to reach chemical equilibrium with respect to quartz or other silica minerals; (3) the silica concentration attained at depth remains constant as the water moves from the reservoir to the sampling point.
For waters of the Klamath Falls area, assumption (1) is probably true. Although virtually no quartz occurs in the upper Tertiary rocks of the region, silicate minerals are abundant in the basaltic rocks and deeply circulating thermal waters may encounter rhyolites of Eocene or Oligocene age, or quartz-rich sediments of Eocene age, both of which underlie younger Tertiary rocks in adjacent ares (Williams, 1949; Peterson and McIntyre, 1970). The high silica concentrations in the cold spring waters indicate that silica in some form is abundantly available even in the shallow aquifers.

In spite of a general availability of silica, it is possible that the geothermal system at the present time is largely restricted to flow paths and conduits that have been depleted in silica. There is no evidence, for example, for recent silicification comparable to the older silicification that pervades the rocks surrounding the geothermal areas, and this may indicate that silica concentrations, as well as flow volumes, have decreased during the life of the system. Although this question has not been resolved by the present study, the uniform silica concentrations of hot waters occurring over a wide area suggest that silica saturation has been generally attained by the thermal waters. In light of this conclusion, the second assumption relating to the time required for equilibration with quartz or other silica minerals is probably also a reasonable one for the Klamath Falls geothermal system. The assumption is further supported by results of tritium analyses, discussed below, which indicate that the thermal waters have had residence times on the order of 10 years.

The third assumption, specifying that silica concentrations remain constant as the thermal waters ascend to the surface, is probably not completely met. The relatively constant silica concentrations of the hotter waters of the region suggest, however, that the amount of wallrock interaction and dilution by mixing is minimal. Supporting this conclusion are the constant $\left(\mathrm{HCO}_{3}+\mathrm{CO}_{3}\right) / \mathrm{Cl}$ ratios, the high $\mathrm{Na} / \mathrm{K}$ and $\mathrm{Ca} / \mathrm{HCO}_{3}$ ratios, and the fairly small increases in oxygen isotope concentrations (see next section of this report), all of which are indicators of relatively low reservoir temperatures. As the geothermal waters ascend toward the surface, therefore, silica concentrations would not be expected to change appreciably through either precipitation or further solution of silica. Estimates of the probable extent of mixing in the thermal waters are given in the next section.

Several silica geothermometers are given by Fournier and Rowe (1966) and Fournier and Truesdell (1974). Briefly, the four models used for this study are based in the following assumptions: (1) Quartz saturation with adiabatic cooling (Qtz. Adiab.), (2) quartz saturation with conductive cooling (Qtz. Cond.), (3) chalcedony saturation with conductive cooling, and (4) quartz saturation and mixing with cold, meteoric wa- 
ter. Computations were made by means of Geotherm, a computer program written by Truesdell (1976b). Results are listed in table 7 and shown in the graph of figure 8 .

Input data for the mixing model include a silica concentration of $45 \mathrm{mg} \mathrm{L}^{-1}$ and a temperature of $20^{\circ} \mathrm{C}$ for the cold water. The temperature chosen for the coldwater component is typical of cooler waters in the vicinity of the geothermal areas. Slightly lower estimated reservoir temperatures would be obtained if the coldest ground-water temperatures in the region were used for the analysis. The silica concentration chosen for the cold-water component is tyical of concentrations in basaltic aquifers of the area. Somewhat higher estimated reservoir temperatures would be obtained if lower silica concentrations were used.

Estimated reservoir temperatures based on the quartz geothermometer have a narrow range for most of the hot waters but a much broader range for the warm waters. Reservoir temperatures calculated for nine of the hotter waters by means of the quartz conductive model range from $124^{\circ}$ to $143^{\circ} \mathrm{C}$; those calculated by means of the chalcedony model range from $94^{\circ}$ to $108^{\circ} \mathrm{C}$. When the silica mixing model is applied, temperatures range from $126^{\circ}$ to $184^{\circ} \mathrm{C}$ for chalcedony.

Athough nearly all the estimated temperatures fall within reasonable limits, they represent an uncomfortably large range of values for each of the approaches. In evaluating the various approaches, an important criterion is the fact that for geothermal waters having temperatures less than about $150^{\circ} \mathrm{C}$, silica equilibration may occur with respect to chalcedony rather than quartz (R. O. Fournier, oral commun., 1976). However, the reservoir temperatures estimated from chalcedony concentrations are lower than observed temperatures in thermal wells, indicating that these direct estimates are inadequate and suggesting that mixing models are probably required. Final conclusions regarding these approaches and the best estimate of reservoir temperature are deferred to the section "Isotopes in Ground Water."

Estimated reservoir temperatures for warm transitional waters in the area (table 7) are extremely erratic and are probably unreliable. Although it is virtually certain that these are mixed waters, mixing models fail to provide reasonable estimates of reservoir

TABLE 7.-Estimates of reservoir temperature based on chemical relations in ground water

\begin{tabular}{|c|c|c|c|c|c|c|c|c|c|c|c|c|}
\hline \multirow{3}{*}{$\begin{array}{l}\text { Seq. } \\
\text { No. }\end{array}$} & \multirow{3}{*}{ Owner or name } & \multirow{3}{*}{$\begin{array}{l}\text { Well } \\
\text { depth } \\
\text { ft. }\end{array}$} & \multirow{3}{*}{$\begin{array}{c}\text { Measured' } \\
\text { temp. } \\
{ }^{\circ} \mathrm{C}\end{array}$} & \multirow{3}{*}{ Date } & \multirow{3}{*}{$\begin{array}{c}\mathrm{Qtz}^{2}{ }^{2} \\
\text { (adiab.) }\end{array}$} & \multirow{3}{*}{$\begin{array}{c}\text { Qtz. }^{2} \\
\text { (cond.) }\end{array}$} & \multirow{3}{*}{$\begin{array}{c}\text { Chalced. }{ }^{2} \\
\text { (cond.) }\end{array}$} & \multicolumn{4}{|c|}{ Calculated reservoir temperature $\left({ }^{\circ} \mathrm{C}\right)$} & \multirow{3}{*}{$\begin{array}{l}\delta^{18} \mathrm{O} \text { in } \\
\text { sulfate }^{5}\end{array}$} \\
\hline & & & & & & & & \multicolumn{2}{|c|}{$\mathrm{Na} / \mathrm{K}+\beta \sqrt{\mathrm{Ca}} / \mathrm{Na}^{3}$} & \multicolumn{2}{|c|}{ Mixing models' } & \\
\hline & & & & & & & & $\beta=1 / 3$ & $\beta=4 / 3$ & Quart & Chalced. & \\
\hline \multicolumn{13}{|c|}{ Hot wells and springs } \\
\hline 6 & OIT Well \#6. & 1805 & 88 & $08-05-72$ & 127 & 131 & 103 & 108 & 71 & 150 & 112 & 185 \\
\hline 7 & Medo-Bel Dairy & 765 & 81 & $01-24-55$ & 122 & 126 & 96 & 109 & 75 & 150 & 109 & 185 \\
\hline 8 & J. E. Friesen & 564 & 73 & $02-19-55$ & 124 & 130 & 101 & 109 & 75 & 163 & 127 & \\
\hline 13 & Mills School & 800 & 89 & $08-07-75$ & 121 & 124 & 94 & 83 & 67 & 135 & 99 & 179 \\
\hline 14 & Lois Serruys & 528 & 71 & $12-22-54$ & 122 & 127 & 98 & 106 & 73 & 126 & 122 & \\
\hline 28 & Olene Gap Spg & & 74 & $03-09-74$ & 130 & 136 & 108 & 130 & 80 & 142 & 127 & 196 \\
\hline 44 & O. H. Osborn & 418 & 90 & $05-31-74$ & 127 & 131 & 103 & 114 & 83 & 154 & 114 & 135 \\
\hline 46 & Jack Liskey & 282 & 93 & $05-09-74$ & 128 & 131 & 103 & 111 & 82 & 152 & 111 & 138 \\
\hline 58 & Assembly of God & 363 & 87 & $07-17-74$ & 137 & 143 & 117 & 111 & 74 & 184 & 144 & $-\ldots-$ \\
\hline \multicolumn{13}{|c|}{ Warm wells and springs } \\
\hline 1 & Eagle Point Spring & & 35 & $04-06-75$ & 116 & 124 & 94 & 190 & 170 & $>200$ & 200 & -.... \\
\hline 17 & Mazama School & 972 & 61 & & 138 & 147 & 120 & 129 & 126 & 197 & 163 & $\ldots$ \\
\hline 20 & U.S. Air Force & 500 & 31 & $10-17-72$ & 99 & 105 & 73 & 209 & 129 & 163 & 123 & - n \\
\hline 22 & Falcon Hts. School & 1050 & 37 & $05-07-74$ & 117 & 125 & 96 & 181 & 104 & $>200$ & $>200$ & $\ldots$ \\
\hline 23 & Alfred Jacobsen & 155 & 30 & $05-20-74$ & 108 & 115 & 84 & 221 & 131 & $>200$ & $>200$ & $-\ldots$ \\
\hline 50 & Jack O'Connor & -700 & 38 & $05-09-74$ & 108 & 115 & 84 & 116 & 83 & 196 & 163 & - n \\
\hline 56 & O'Connor Livestock & 770 & 30 & $06-06-74$ & 117 & 125 & 96 & 123 & 72 & $>200$ & $>200$ & ----- \\
\hline \multicolumn{13}{|c|}{ Slightly warm waters } \\
\hline 15 & Howard Holliday Spg. & & 25 & $05-22-74$ & 72 & 76 & 42 & 157 & 56 & -....... & -..... & -...-- \\
\hline 18 & Weyerhaeuser \#4 & 545 & 22 & $10-16-73$ & $7 \overline{9}$ & 83 & 49 & 159 & 65 & $\ldots$ & $\ldots$ & $\ldots$ \\
\hline 25 & Melvin McCollum & 223 & 25 & $05-28-74$ & 98 & 104 & 72 & 178 & 50 & $\ldots$ & -..... & $\ldots$ \\
\hline 26 & Claude Shuck & 1060 & 24 & $05-30-74$ & 101 & 108 & 77 & 203 & 84 & ....... & 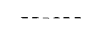 & -..-- \\
\hline 27 & Ray Bixler & 460 & 22 & $05-29-74$ & 95 & 101 & 69 & 182 & 55 & -n- & 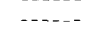 & - n- \\
\hline 30 & Robert Langley & 350 & $2 \overline{3}$ & $05-04-74$ & 96 & 102 & 70 & 200 & 78 & $-\cdots$ & - no- & 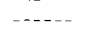 \\
\hline 35 & Len Dobry & 612 & 21 & $05-04-74$ & 107 & 115 & 84 & 180 & 88 & -...... & $\ldots$ & $\ldots$ \\
\hline 36 & Lester Brookshire & 1210 & 25 & $05-04-74$ & 83 & 87 & 53 & 173 & 57 & -...- & $\ldots$ & -....-- \\
\hline 38 & Geo. Stacy Co. & 916 & 25 & $06-05-74$ & 81 & 86 & 52 & 183 & 61 & -...- & $-\ldots$. & $\ldots \ldots$ \\
\hline 39 & Monte Dehlinger & 148 & 26 & $06-06-74$ & $\begin{array}{l}01 \\
99\end{array}$ & 106 & 74 & 207 & 73 & n & n & - \\
\hline 40 & J. K. O'Neil & 83 & 23 & $05-04-74$ & 96 & 102 & 70 & 194 & 88 & -....- & $\ldots \ldots$ & $\ldots$ \\
\hline 43 & Dan O'Connor & 85 & 24 & $05-07-74$ & 90 & 95 & 62 & 207 & 91 & $\ldots$ & $\ldots$ & $\ldots$ \\
\hline 45 & Abe Boehm & 155 & 25 & $05-30-74$ & 127 & 137 & 109 & 132 & 87 & $\ldots \ldots$ & $\ldots$ & $\ldots$ \\
\hline 47 & Clyde Dehlinger & 100 & 24 & $06-05-74$ & 112 & 120 & 90 & 189 & 95 & $\ldots$ & $\ldots$ & - \\
\hline 48 & Bill Hill & 820 & 20 & $06-06-74$ & 71 & 74 & 40 & 217 & 83 & $\ldots-\ldots$ & $\ldots \ldots$ & $\ldots \ldots$ \\
\hline 51 & Jack Liskey & 95 & 22 & $05-09-74$ & 126 & 137 & 109 & 121 & 115 & $\ldots$ & $\ldots$ & $-\ldots-$ \\
\hline 54 & Town of Merrill & 1088 & 21 & $02-18-55$ & 86 & 90 & 57 & 155 & 71 & $\ldots$ & $\ldots$ & $\ldots$ \\
\hline 55 & Pope's Meat Co. & 1128 & 22 & $06-06-74$ & 69 & 73 & 39 & 161 & 67 & -...... & $\ldots$ & - n \\
\hline 57 & George Carter & 67 & 22 & $06-06-74$ & 89 & 94 & 61 & 156 & 83 & - n-..- & $\ldots \ldots$ & $\ldots$ \\
\hline
\end{tabular}


TEMPERATURE, IN DEGREES CELSIUS

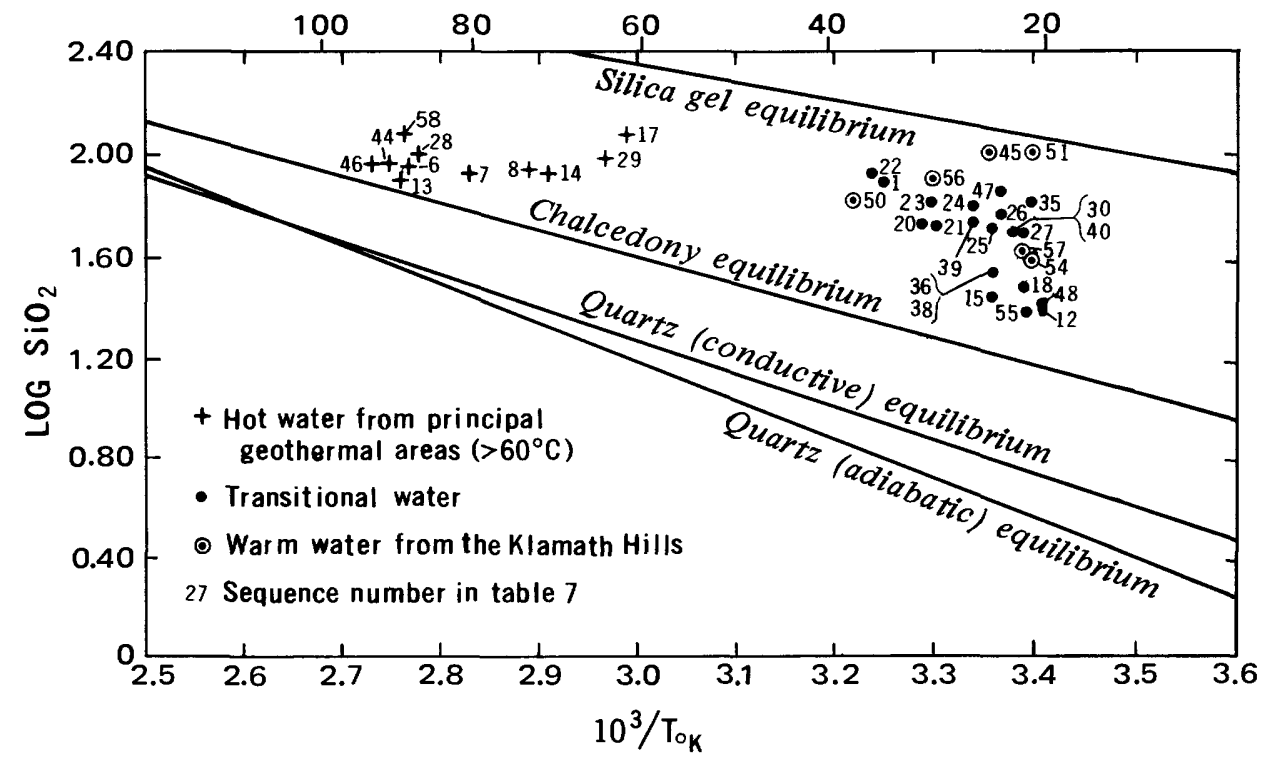

Figure 8.-Temperature of ground water versus log silica concentration. Straight lines show empirical relations of temperature to equilibrium concentrations of quartz, chalcedony, and silica gel (Fournier, 1977).

temperatures. The most likely causes for the failure of the mixing models are the general availability of amorphous silica and the general presence of nonequilibrium chemical conditions in the deposits permeated by the warm waters.

A second quantitative geothermometer that has been applied successfully to geothermal systems is the Na-K-Ca geothermometer (Fournier and Truesdell, 1973). Based on worldwide data from springs and wells, the following empirical expression has been formulated:

$$
\begin{aligned}
\log (\mathrm{Na} / \mathrm{K})+\beta \log (\sqrt{\mathrm{Ca} / \mathrm{Na}}) & \\
= & \frac{1647}{273+\mathrm{T}}-2.24=\mathrm{K}^{*}
\end{aligned}
$$

where concentrations of $\mathrm{Na}, \mathrm{K}$, and $\mathrm{Ca}$ are in moles, $T$ is temperature in degrees Celsius, $\beta=4 / 3$ for waters equilibrated at less than $100^{\circ} \mathrm{C}$ and $1 / 3$ for waters equilibrated at more than $100^{\circ} \mathrm{C}$.

Data from table 5 were used to obtain a value of $\mathrm{K}^{*}$ for each sample, and this value was then plotted versus the reciprocal of the measured temperature in degrees Kelvin. The results are shown in figure 9 along with a line representing the Fournier-Truesdell expression. Projection of the $\mathrm{K}^{*}$ values horizontally onto the line gives the apparent temperature of equilibration in the reservoir. Calculated equilibration temperatures based on the relations shown in figure 9 for two values of $\beta$ are listed in table 7.
The graph shows that the majority of water samples fall into two groups with roughly similar estimated reservoir temperatures. The left-hand group comprises the hot waters of the area; projection of these points onto the line produces estimated reservoir temperatures that, in most cases, are lower than actual water temperatures. This result is caused by $\mathrm{Na} / \mathrm{K}$ ratios that are higher than expected in relation to $\sqrt{\mathrm{Ca}} / \mathrm{Na}$ ratios and observed temperatures.

The group of data points on the right side of the graph in figure 9 represents warm, and presumably mixed, waters with wide ranges of concentrations of $\mathrm{Na}, \mathrm{Ca}$, and K. Estimated temperatures of last rockwater equilibrium for many of these samples are similar to estimates derived for the hot waters (table 7). Five samples give anomalously high estimates.

The two major groups of samples in figure 9 are distributed so that a line connecting their centers is nearly horizontal. Thus, values of $\mathrm{K}^{*}$ along this line would vary only slightly with large changes in temperature. It might be expected, therefore, that mixing models using typical hot and warm waters would change estimated reservoir temperatures only slightly from those estimated for the hot waters alone.

In order to test the effect of mixing, trials were made using mixtures of a typical hot water (No. 58: $\mathrm{Na}=213$ $\mathrm{mg} \mathrm{L}^{-1} ; \mathrm{Ca}=28 \mathrm{mg} \mathrm{L}^{-1} ; \mathrm{K}=4.6 \mathrm{mg} \mathrm{L}^{-1}$ ) and averages for warm water between $15^{\circ}$ and $25^{\circ} \mathrm{C}\left(\mathrm{Na}=25 \mathrm{mg} \mathrm{L}^{-1}\right.$ : $\mathrm{Ca}=12 \mathrm{mg} \mathrm{L}^{-1} ; \mathrm{K}=4 \mathrm{mg} \mathrm{L}^{-1}$ ). With mixtures ranging 


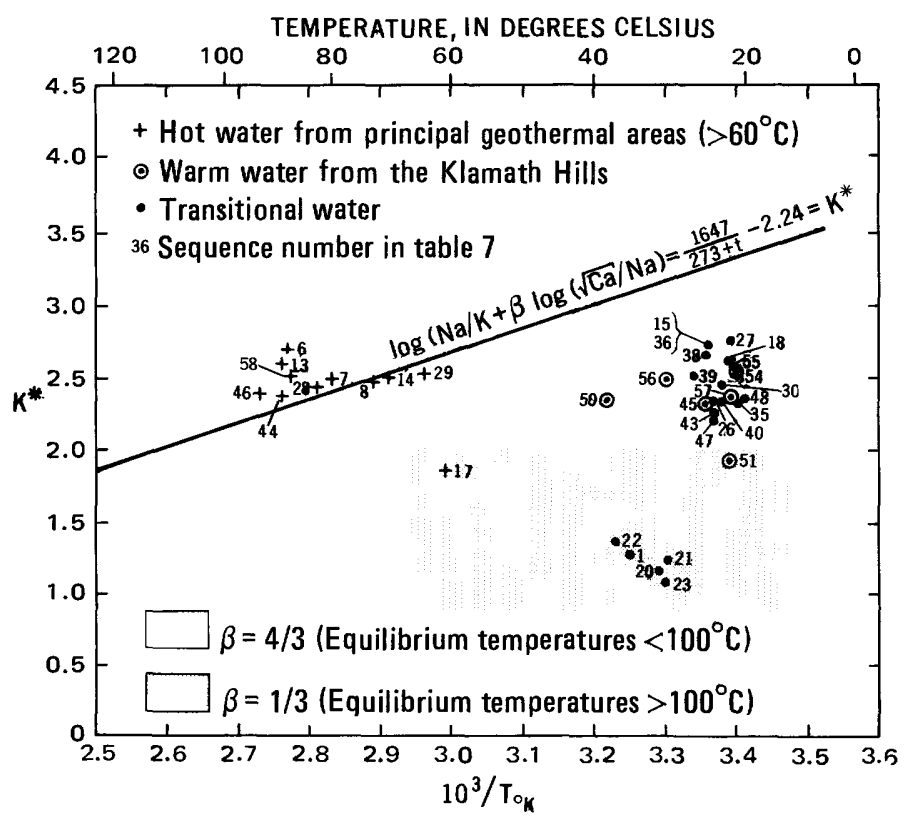

Figure 9.-Temperature of ground water versus $\log (\mathrm{Na} / \mathrm{K})+\beta \log$ $(\sqrt{\mathrm{Ca}} / \mathrm{Na})$. Straight line shows empirical relation to equilibrium reservoir temperatures (Fournier and Truesdell, 1974).

from 15 to 45 percent warm water, reservoir temperatures estimated by the $\mathrm{Na}-\mathrm{K}-\mathrm{Ca}$ geothermometer ranged only from $74^{\circ}$ to $75^{\circ} \mathrm{C}$.

Additional trials using an average composition for five cold waters $\left(<5^{\circ} \mathrm{C}\right)$ in basaltic aquifers $(\mathrm{Na}=25 \mathrm{mg}$ $\mathrm{L}^{-1} ; \mathrm{Ca}=12 \mathrm{mg} \mathrm{L}^{-1} ; \mathrm{K}=4 \mathrm{mg} \mathrm{L}^{-1}$ ) produced only a slight improvement in estimated reservoir temperatures. For mixtures of 15 to 45 percent cold water, estimated reservoir temperatures ranged from $78^{\circ}$ to $86^{\circ} \mathrm{C}$.

Analysis of the terms incorporated in the geothermometer shows that molal ratios of $\mathrm{Na} / \mathrm{K}$ decrease by an order of magnitude between the hot waters and the cold or warm waters, but that ratios of $\sqrt{\mathrm{Ca}} / \mathrm{Na}$ have an offsetting increase of nearly an order of magnitude. When the cation concentrations of hot and warm or cold waters are combined in mixing models and logs of the resulting ratios are added in the geothermometer expression, the net effect of mixing is very small. For this reason, simple mixing models used with the cation geothermometer do not appear to be capable of providing reliable estimates of reservoir temperature for these waters.

\section{ISOTOPES IN GROUND WATER}

Samples of water from a number of wells and springs in the vicinity of Klamath Falls were analyzed for concentrations of isotopes of oxygen $\left({ }^{18} \mathrm{O}\right)$ and hydrogen (deuterium and tritium) (table 8). Analyses of these isotopes have been used elsewhere to ascertain the origin and the history of thermal waters. (See for exam-
TABLE 8.-Analyses of the isotopes oxygen-18, deuterium, and tritium in ground water and Klamath Lake water

\begin{tabular}{|c|c|c|c|c|c|}
\hline $\begin{array}{l}\text { Sequence } \\
\text { No. }\end{array}$ & Name & $\begin{array}{l}8^{18} \mathbf{O}^{1} \\
(0 / 00)\end{array}$ & $\begin{array}{c}\text { SDeuterium } 1 \\
(0 / 00)\end{array}$ & $\begin{array}{l}\delta^{18} \mathrm{O} \text { in } \\
\text { sulfate } \\
(0 / 00)\end{array}$ & $\begin{array}{c}\text { Tritium } \\
\text { (TU) }\end{array}$ \\
\hline $\begin{array}{l}\text { Hot wa } \\
6 \\
7 \\
13 \\
17 \\
28 \\
29 \\
44 \\
46 \\
58\end{array}$ & $\begin{array}{l}\text { ters }\left(>60^{\circ} \mathrm{C}\right) \\
\text { OIT \#6 } \\
\text { Medo Bel Dairy } \\
\text { Mills School } \\
\text { Mazama School } \\
\text { Olene Gap Spring } \\
\text { L. Jones spring } \\
\text { O. Osborn } \\
\text { J. Liskey } \\
\text { Assembly of God }\end{array}$ & $\begin{array}{l}-14.4^{\mathrm{G}} \\
-14.6^{\mathrm{G}} \\
-14.83^{\mathrm{N}} \\
-14.2^{\mathrm{C}} \\
-13.3^{\mathrm{G}} \\
-13.5^{\mathrm{C}} \\
-14.6^{\mathrm{G}} \\
-14.6^{\mathrm{G}} \\
-14.75^{\mathrm{C}}\end{array}$ & $\begin{array}{l}-118.7^{\mathrm{LW}} \\
-119.4^{\mathrm{LW}} \\
-121.8^{\mathrm{LW}} \\
-117.0^{\mathrm{C}} \\
-111.6^{\mathrm{C}} \\
-110.2^{\mathrm{C}} \\
-117.0^{\mathrm{LW}} \\
-116.6^{\mathrm{LW}} \\
{ }^{\mathrm{C}}-120.0^{\mathrm{C}}\end{array}$ & $\begin{array}{l}-5.45^{\mathrm{N}} \\
-5.45^{\mathrm{N}} \\
-4.94^{\mathrm{N}} \\
-4.82^{\mathrm{N}} \\
-1.85^{\mathrm{N}} \\
-2.13^{\mathrm{N}}\end{array}$ & $\begin{array}{c}1.6 \pm 0.5^{\mathrm{TW}} \\
\overline{1.1 \pm 0.6^{\mathrm{TW}}} \\
1 . \overline{3} \pm 0.5^{\mathrm{TW}}\end{array}$ \\
\hline
\end{tabular}

Warm waters from the Klamath Hills $\left(21^{\circ} \mathrm{C}-25^{\circ} \mathrm{C}\right)$

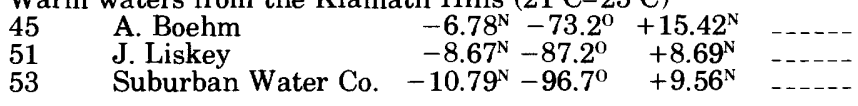

Warm waters $\left(20^{\circ} \mathrm{C}-37^{\circ} \mathrm{C}\right)$

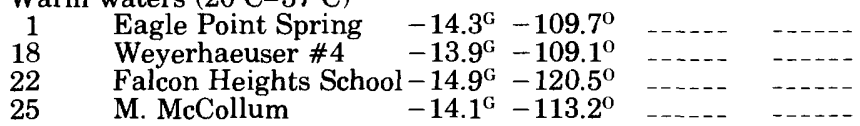

Cold waters $\left(<20^{\circ} \mathrm{C}\right)$

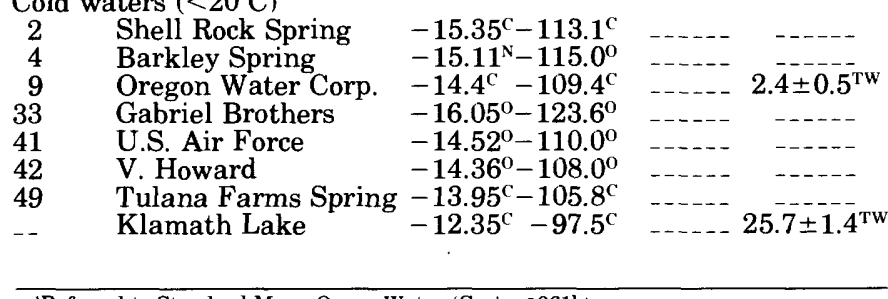

'Referred to Standard Mean Ocean Water (Craig, 1961b)

Analysts

C T. B. Coplen, Reston, Va.

G Geochron Laboratories, Denver, Colo

N N. L. Nehring, Menlo Park, Calif.

O James O'Neil,'Menlo Park, Calif.

LW L. D. White, Menlo Park, Calif.

ple, International Atomic Energy Agency, 1974; Taylor, 1974.)

\section{OXYGEN-18 AND DEUTERIUM 1SOTOPES}

The correlation between concentrations of oxygen- 18 and deuterium in precipitation is generally given by the expression

$$
\delta \mathrm{D}=8 \delta^{18} \mathrm{O}+\mathrm{d}
$$

where $\delta \mathrm{D}$ and $\delta^{18} \mathrm{O}$ are ratios of deuterium and ${ }^{18} \mathrm{O}$ to $\mathrm{H}$ and ${ }^{16} \mathrm{O}$, respectively, expressed in parts per thousand $(\%)$ as departures from the ratios in Standard Mean Ocean water (SMOW) (Craig, 1961a, b), and d is typically 10 . The "meteoric line" resulting from the above expression is shown in figure 10 along with data from 25 water samples from the Klamath Falls area.

The cold, fresh waters of the area, represented by samples $4,9,41,42$, and 49 in figure 10 appear to establish a trend parallel to but offset from the theoret- 
ical meteoric line. Although one cold-water sample, number 2 (Shell Rock Spring), is anomalous, the trend established by the five remaining samples may be taken as a probable baseline for most locally derived recharge waters. A seventh cold-water sample, number 33 , derived from a 1,004-foot well located near Olene Gap, also appears to be anomalous but may represent high-altitude recharge from Stukel or Hogback mountain.

Transitional waters are represented by only four samples, two of which seem to have anomalous $\delta^{18} \mathrm{O} / \delta \mathrm{D}$ ratios. The trend of these samples from left to right parallel to the meteoric line is in keeping with a general trend of decreasing temperature in the four samples and also with their relative positions in the trends of ionic ratios in figure 6. Uncertainties resulting from possible errors of analyses and the small number of samples would seem to preclude attempts to draw general conclusions from the isotope concentrations in these transitional waters.

Three warm waters from the Klamath Hills, samples 45,51 , and 53, show large displacements from the meteoric trend in figure 10 and demonstrate further that these waters differ significantly from both hot waters and other warm waters in the area. (See section on "Relations Among Dissolved Constituents," this report.) The positions of these samples are consistent with the supposition that the Klamath Hills warm waters are mixtures whose components have been subjected to low-temperature evaporation.

Nine samples of hot water from the three principal geothermal areas are included in the graph of figure 10. These waters have apparently been enriched in ${ }^{18} \mathrm{O}$ during their passage through the geothermal reservoir, with increases in $\delta^{18} \mathrm{O}$ ranging from 0.8 to $1.4 \%$. The increase is small compared to that observed in high-temperature geothermal systems such as Steamboat Springs, Nev. or The Geysers, California, which have increases in $\delta^{18} \mathrm{O}$ as great as 3 to $5 \%$ (White, 1968). The isotope data suggest, therefore, that the Klamath Falls hot waters have not equilibrated at extremely high reservoir temperatures, or, alternatively, that they have been diluted by mixing with cooler waters. These alternatives have been discussed in the preceding section of this report and will be discussed further in the next section.

The hotter thermal waters from both the Klamath Falls hot-well area (samples 6, 7, 13, and 58) and from the Klamath Hills (samples 44 and 46 ) have a fairly small range of $\delta^{18} \mathrm{O}$ values. They differ more widely, however, in their deuterium concentrations and in their displacement from the presumed meteoric line. Assuming these differences to be significant, they indicate that two groups of hot waters originate in slightly differing meteoric waters and are subjected to slightly differing reservoir conditions. Thus the isotope data are consistent with the chemical analyses and temperature data for these waters, which together suggest that although the reservoirs and sources of recharge are generally similar for the two groups, small variations occur as the result of differing local conditions.

Two samples of hot water from the geothermal area at Olene Gap (samples 28 and 29) differ significantly from other hot waters, principally in having higher concentrations of calcium, ${ }^{18} \mathrm{O}$, and deuterium. One explanation for the high concentrations of ${ }^{18} \mathrm{O}$ and deuterium in these samples is that the altitude at which recharge occurs is lower than that of other recharge waters. An alternative explanation for the composition of samples 28 and 29 is that either the recharge water or the thermal water has undergone low-temperature evaporation. Although neither of these explanations is clearly supported or excluded by the available data, both would imply that the geothermal reservoir at Olene Gap is separated to some degree from other geothermal reservoirs in the area.

Some of the relations suggested by deuterium and ${ }^{18} \mathrm{O}$ ratios in figure 10 may be substantiated and clarified by plotting both deuterium and $\delta^{18} \mathrm{O}$ versus a conservative ion such as chloride (figure 11). The apparent mixing trend of Klamath Hills warm waters is clearly shown in figure 11, as are groupings of thermal waters on differing trend lines. Samples 28 and 29 (Olene Gap springs) are separated from other thermal waters, and there is the suggestion that sample 17 , a

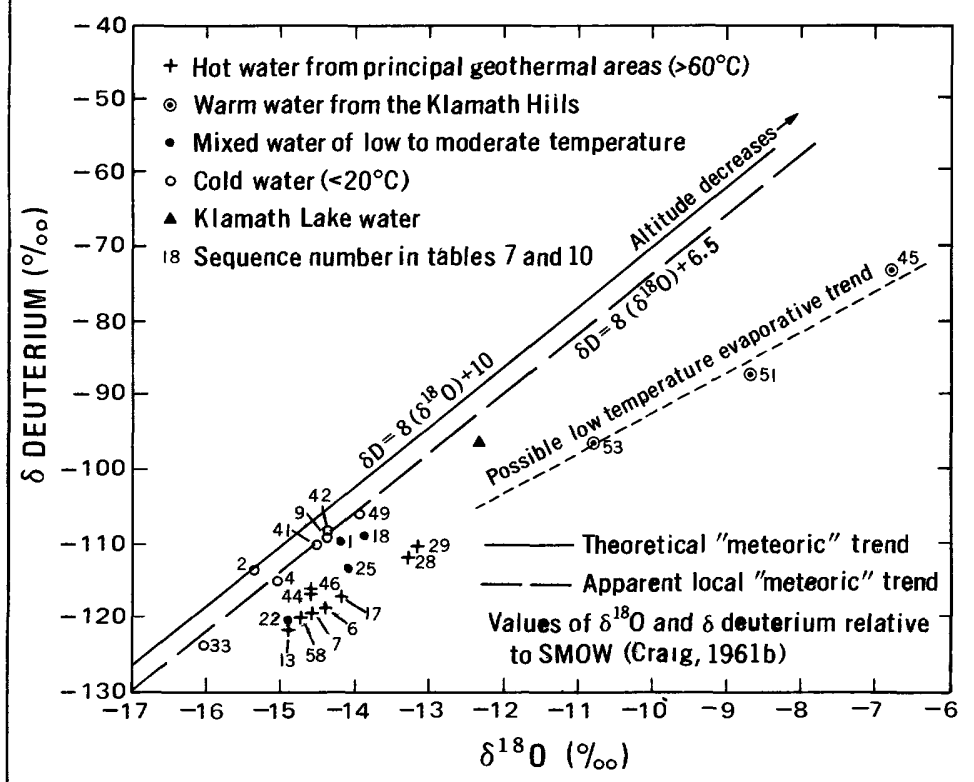

FIGURE 10.- $\delta$ oxygen-18 versus $\delta$ deuterium in ground water and lake water. 


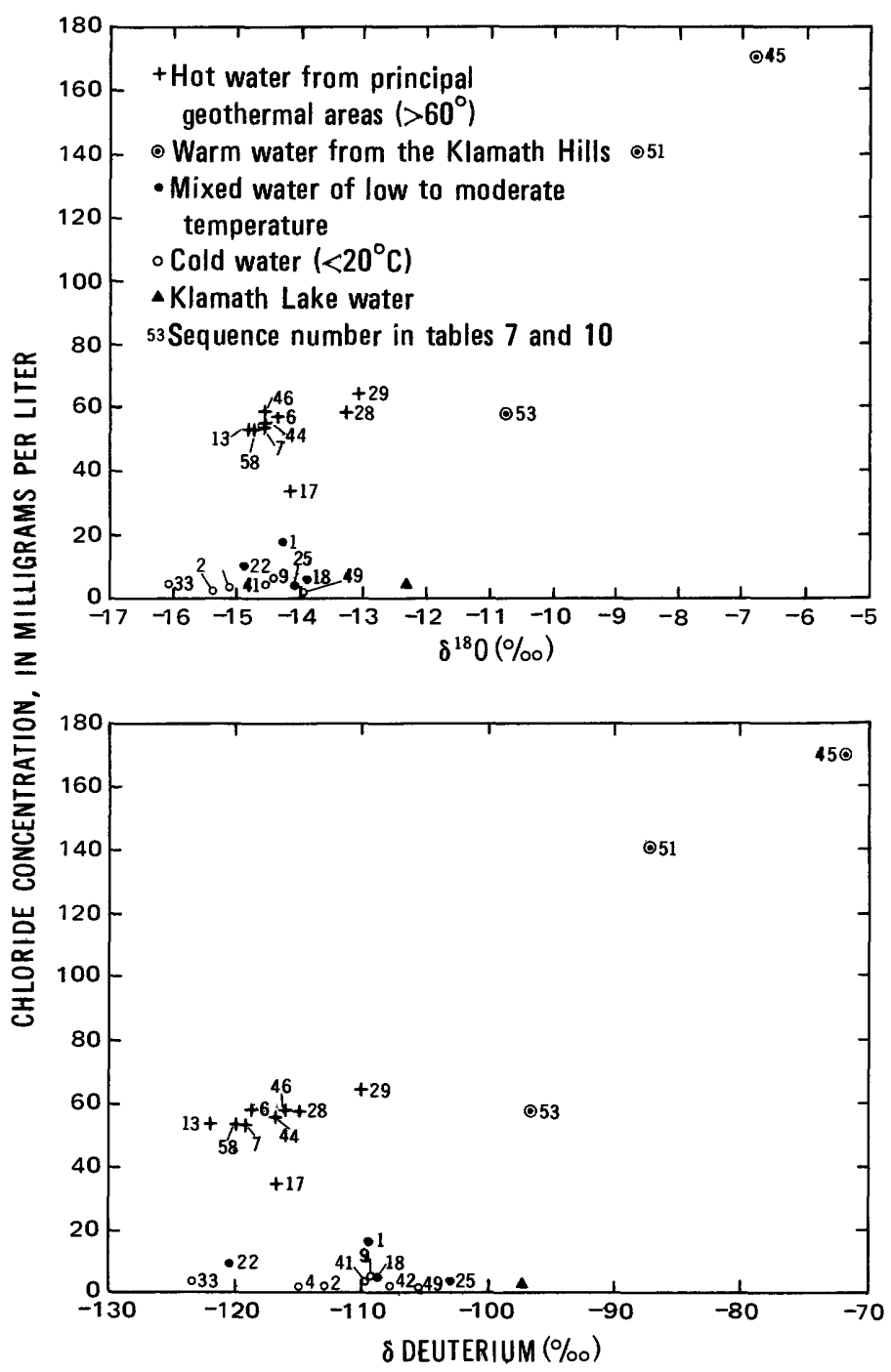

Figure 11-Chloride concentration versus $\delta$ oxygen-18 and $\delta$ deuterium in ground water and lake water.

water having somewhat anomalous chemical characteristics, falls on a possible mixing trend with the Olene Gap springs.

\section{TRITIUM CONCENTRATIONS}

Four samples of ground water and one sample of Klamath Lake water were analyzed for tritium concentrations (table 8 ). These analyses represent only one point in time and hence do not provide a basis for reliable estimates of residence time in the aquifer. However, some qualitative conclusions are possible.

Samples 6 and 46, from OIT 6 and the Liskey hot well, respectively, are clearly older waters, possibly derived from pre-1954 meteoric water. Sample 9, from a cold, deep well used for municipal supply, is also an older water which may predate the 1954 atomic-bomb input. Sample 28 (Olene Gap hot spring), has a significant amount of tritium, indicating the presence of post-1954 meteoric water.

On the basis of tritium concentrations in thermal and nonthermal waters, a mixing model can be constructed from which the apparent reservoir temperature for the Olene Gap springs can be estimated. Utilizing the tritium concentration in sample 28 (7.1 TU), and assuming that the tritium concentration in the geothermal reservoir is zero, and that of the cold-water component is the same as Klamath Lake (26 TU), the mixing proportions are determined and applied to observed temperatures. The calculated reservoir temperature is $112^{\circ} \mathrm{C}$. When observed silica concentrations and geothermometers are used in this tritium mixing model, estimated reservoir temperatures are $121^{\circ}$ and $146^{\circ} \mathrm{C}$, respectively, for the chalcedony and quartz conductive geothermometers.

Although these results are reasonable, no great weight should be attached to them in view of the large uncertainties involved. In particular, the choice of a tritium concentration for the cold-water component is arbitrary and appears to be lower than would be expected for meteoric water in this region (T. A. Wyerman, oral commun., 1978). It is clear, however, from the form of the mixing expression, that any increase in the assumed tritium concentration of the cold water would result in even smaller calculated fractions of cold water and consequently in lower apparent reservoir temperatures. Conversely, trials with assumed tritium concentrations in the cold water smaller than about $15 \mathrm{TU}$ result in calculated reservoir temperatures that are much higher than those estimated by other means and are probably unreasonable in the light of the chemical nature of the water. If other assumptions of the mixing model are reasonable, therefore, it is probable that the tritium concentration in the cold-water component of the Olene Gap springs is in the range 15 to $30 \mathrm{TU}$, and that the calculation correctly indicates the presence of a significant fraction of fairly young water in the mixture. A cold-water fraction as old as that in sample 9, a cold deep water derived from Tertiary basaltic rocks, is apparently ruled out by the mixing model relations.

\section{ISOTOPE MIXING MODELS}

Isotope concentrations in thermal waters can be used to gain insight into several questions that are of paramount importance in assessing the energy content of a geothermal system. These questions are: (1) Do the waters rise from a single extensive reservoir? (2) to what extent are the thermal waters mixtures of shallow cold water and hotter water from the geothermal reservoirs? and (3) what is the temperature of the re- 
servoir? Unequivocal answers to these questions probably cannot be obtained from the data at hand, but the graphical analysis described below may point toward probable answers for the Klamath Falls geothermal system.

Figure 12 is a large-scale version of a part of the graph of figure 10 showing $\delta$ oxygen-18 versus $\delta$ deuterium. In figure 12, simple mixing models for the geothermal waters have been tested by trial and error. The procedure is based on the following assumptions: (1) Recharge waters for the geothermal reservoir have positions along the observed cold-water trend line; and (2) thermal waters are simple mixtures of these cold waters with a single hypothetical reservoir water having isotope compositions specified by arbitrarily chosen points, $\mathrm{P}_{1}$ and $\mathrm{P}_{2}$, for example.

Hot-water and cold-water fractions of each thermal water can be calculated from the geometric proportions of straight lines connecting hypothetical cold waters, thermal water, and the hypothetical reservoir waters, as is shown for sample 29 and reservoir water $P_{2}$. Based on an assumed cold-water temperature of $20^{\circ} \mathrm{C}$, apparent temperatures of the reservoir water are calculated by means of the expression,

$$
\mathrm{T}_{m}+\mathrm{f}_{r} \mathrm{~T}_{r}+\mathrm{f}_{c} \mathrm{~T}_{c}
$$

where $\mathbf{T}_{m}$ is observed temperature in the mixed water, $\mathrm{T}_{r}$ and $\mathrm{T}_{c}$ are temperatures in the reservoir and cold water, respectively, and $\mathrm{f}_{r}$ and $\mathrm{f}_{c}$ are fractions of reservoir water and cold water.

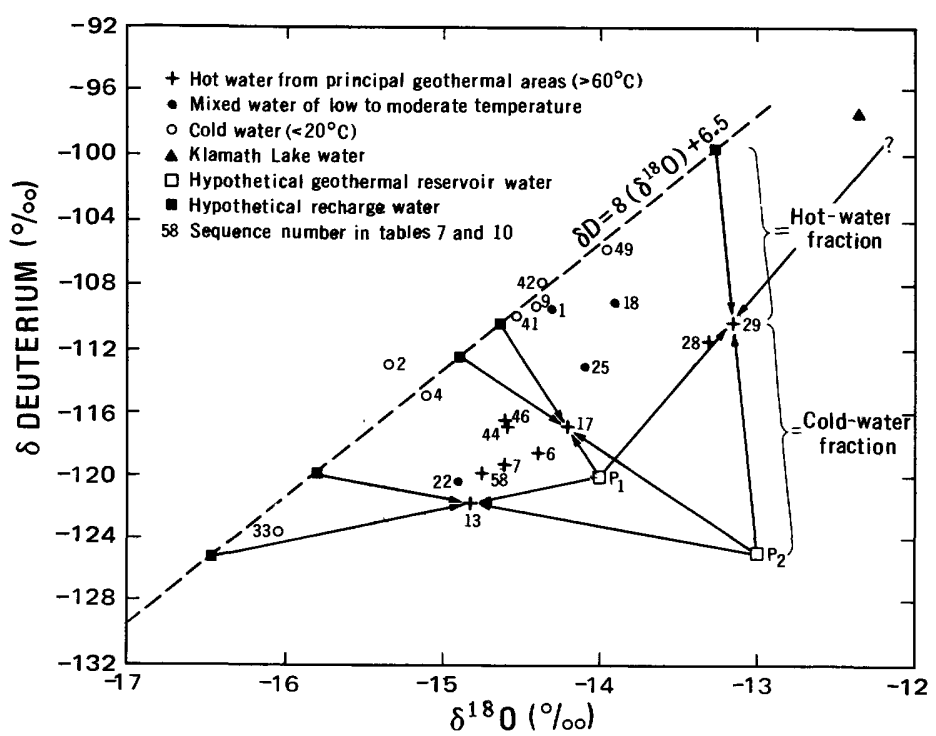

FigURE 12.-Mixing proportions of thermal and meteoric waters based on $\delta$ xygen- 18 and $\delta$ deuterium relations and hypothetical geothermal reservoir waters.
Solving equation (1) for $\mathrm{T}_{r}$, the apparent temperature of reservoir water is determined for each observed thermal water (table 9). For a reservoir water in position $\mathrm{P}_{2}$, representing an enrichment in $\delta^{18} \mathrm{O}$ of about $3 \frac{1 / 2}{\%}$, apparent reservoir temperatures range from 130 to $324^{\circ} \mathrm{C}$. This wide range indicates that the simple mixing model fails to account for the observed distribution of thermal waters on the graph in relation to $P_{2}$. As a further test of the model, chloride concentrations in the hypothetical reservoir water may be calculated in the same manner as the temperatures, on the assumption that chloride concentration is a conservative property that is likely to be relatively unaffected by factors other than mixing. The resulting differences in calculated reservoir chloride concentrations (table 9) confirm the conclusion from the temperature calculations that simple mixing with a reservoir water at or near the position of $\mathrm{P}_{2}$ is not an acceptable model. No further calculations were made using this model.

More acceptable results were obtained in a second trial that applied the above procedures to a hypothetical reservoir water at position $P_{1}$ (figure 12). As was true for reservoir water $P_{2}$, however, the range of calculated chloride concentrations shows that a single reservoir fluid at or near $P_{1}$ cannot account for chloride concentrations in all thermal waters. Furthermore, on the basis of additional trials (not indicated in figure 12 ), it is concluded that no single point of origin for a reservoir water could provide consistent results under the assumed conditions of the model.

TABLE 9.-Calculated silica and chloride concentrations and temperatures in the geothermal reservoir

[Based on oxygen-18 and deuterium mixing models derived from figure 12. See text for explanation]

\begin{tabular}{|c|c|c|c|c|c|}
\hline & \multirow[b]{2}{*}{$\begin{array}{l}\text { Calculated } \\
\text { silica } \\
\text { concen- } \\
\text { tration' } \\
\left(\mathrm{mg} \mathrm{L}^{-1}\right)\end{array}$} & \multirow{2}{*}{$\begin{array}{l}\text { Calculated } \\
\text { chloride } \\
\text { concen- } \\
\text { tration } \\
\left(\text { mg L L }^{-1}\right)\end{array}$} & \multicolumn{3}{|c|}{ Calculated reservoir temperature } \\
\hline & & & $\begin{array}{l}\text { Isotope } \\
\text { mixing } \\
\text { model }^{3} \\
\left({ }^{\circ} \mathrm{C}\right)\end{array}$ & $\begin{array}{l}\text { Chalcedony } \\
\text { geother- } \\
\text { mometer }{ }^{4} \\
\left({ }^{\circ} \mathrm{C}\right)\end{array}$ & $\begin{array}{l}\text { Quartz } \\
\text { geother- } \\
\text { mometer } \\
\left({ }^{\circ} \mathrm{C}\right)\end{array}$ \\
\hline \multicolumn{6}{|c|}{ Hypothetical Geothermal Water, $P_{1}$} \\
\hline Sample No. 29 & 136 & 114 & 100 & 131 & 155 \\
\hline 17 & 114 & 50 & 80 & 119 & 145 \\
\hline$(44,46)$ & 147 & 128 & 186 & 136 & 160 \\
\hline 6 & 111 & 81 & 120 & 117 & 143 \\
\hline 7 & 102 & 84 & 116 & 112 & 139 \\
\hline 58 & 155 & 89 & 130 & 140 & 163 \\
\hline 13 & 95 & 80 & 126 & 108 & 135 \\
\hline \multicolumn{6}{|c|}{ Hypothetical Geothermal Water, $\mathrm{P}_{2}$} \\
\hline Sample No. 29 & 169 & 157 & 130 & --- & $-\ldots$ \\
\hline 17 & 179 & 94 & 137 & $-\ldots$ & $\ldots$ \\
\hline$(44,46)$ & 232 & 239 & 324 & $-\ldots$ & --- \\
\hline 6 & 187 & 150 & 209 & $\ldots$ & $\ldots$ \\
\hline 7 & 154 & 161 & 204 & ---- & ---- \\
\hline 58 & 262 & 173 & 237 & -... & --- \\
\hline 13 & 139 & 149 & 220 & --- & $\ldots$ \\
\hline
\end{tabular}

'From isotope mixing model; assumed silica concentration in cold water is $45 \mathrm{mg} \mathrm{L}^{-1}$.
${ }^{2} \mathrm{From}$ isotope mixing model; assumed chloride concentration in cold water is $3 \mathrm{mg} \mathrm{L}$ ${ }^{2}$ From isotope mixing model; assumed chloride concentration in cold
${ }^{3}$ From graph, figure 12; assumed temperature of cold water is $20^{\circ} \mathrm{C}$. 'Based on calculated silica concentrations in first column. 
In this regard, it may also be noted in figure 12 that as the trial points chosen for hypothetical reservoir waters approach the meteoric trend line so as better to satisfy the criteria of consistent and reasonable reservoir temperatures, required position of recharge waters become more dispersed along the meteoric trend line. For a hypothetical reservoir water near point $P_{1}$, for example, recharge points are required to range from the vicinity of the Klamath Lake sample at one extreme to points beyond sample 33 at the lower left representing exceptionally high altitude or dilution.

On the basis of the above graphical procedure, therefore, it would seem most probable, although by no means certain, that two or more reservoir waters of slightly differing isotopic compositions exist. One of these waters may be similar in composition to $P_{1}$. A second reservoir water with significantly different ${ }^{18} \mathrm{O}$ and deuterium concentrations and of differing meteoric origin could then account for the observed compositions of samples 28 and 29, the Olene Gap springs. It is further speculated that Klamath Hills hot waters (samples 44 and 46) and a fairly low-temperature thermal water such as sample 17 (Mazama School) would have to be accounted for by more complex processes involving mixtures of previously warmed waters or conductive cooling.

The data in table 9 show that an isotope mixing model based on hypothetical reservoir water $P_{1}$ produces consistent estimated chloride concentrations and a fairly small range of reservoir temperatures $\left(116^{\circ}\right.$ to $130^{\circ} \mathrm{C}$ ) for Klamath Falls hot-water samples 6, 7, 13, and 58. Although these temperatures are similar to those in table 7 calculated directly from a mixing model based on the chalcedony equilibrium curve (range $99^{\circ}$ to $127^{\circ} \mathrm{C}$ ), they are generally lower than the highest temperatures observed in the hot waters.

As a further test of the isotope mixing model, silica concentrations calculated from this model for hypothetical reservoir water $P_{1}$ may be used with the silica geothermometer (Fournier and Rowe, 1966) to estimate reservoir temperatures. Results of these calculations, given in table 9 for both chalcedony and quartz geothermometers, compare well with the silica mixing-model results in table 7 . These results appear to confirm the isotope mixing model, and they suggest that a reservoir water with an isotopic composition in the vicinity of point $P_{1}$ in figure 12 could be the source of the Klamath Falls hot waters.

It is apparent that only the mixing models based on quartz equilibria produce estimated minimum reservoir temperatures that are generally higher than observed water temperatures. For the four Klamath Falls samples that appear to be most reliable $(6,7,13$, and 58 ), estimated reservoir temperatures range from $135^{\circ}$ to $184^{\circ} \mathrm{C}$ for the quartz mixing model (table 7 ) and from $135^{\circ}$ to $163^{\circ} \mathrm{C}$ for quartz equilibrium in the isotope mixing model (table 9). These data are not sufficiently numerous to justify a statistically derived best estimate, but it appears reasonable to suppose that reservoir temperatures in all three geothermal areas have a minimum value in the range $145^{\circ}$ to $155^{\circ} \mathrm{C}$. In the light of all chemical and isotope data, a best guess of $150^{\circ} \mathrm{C}$ is used in the final section of this report for calculations of heat content in the reservoir.

\section{RESERVOIR TEMPERATURES ESTIMATED FROM OXYGEN ISOTOPES IN DISSOLVED SULFATE}

The concentrations of oxygen-18 in dissolved sulfate can be used as a geothermometer in thermal waters that have equilibrated for long periods of time in a geothermal reservoir (McKenzie and Truesdell, 1977). It is assumed that exchange between the oxygen isotope in the sulfate ion, ${ }^{18} \mathrm{O}\left(\mathrm{SO}_{4}\right)$, and the oxygen isotope in water, ${ }^{18} \mathrm{O}\left(\mathrm{H}_{2} \mathrm{O}\right)$, will have attained equilibrium after residence times that range from 2 years at a temperature of $300^{\circ} \mathrm{C}$ to 18 years at $200^{\circ} \mathrm{C}$ (McKenzie and Truesdell, 1977, p. 53).

Concentrations of ${ }^{18} \mathrm{O}\left(\mathrm{SO}_{4}\right)$ were determined for six hot waters from the Klamath Falls geothermal areas (table 8). As residence times for these waters probably exceed 18 years (see previous section, "Tritium Concentrations"), equilibration between ${ }^{18} \mathrm{O}\left(\mathrm{SO}_{4}\right)$ and ${ }^{18} \mathrm{O}\left(\mathrm{H}_{2} \mathrm{O}\right)$ may be assumed to be virtually complete if reservoir temperatures are not far below $200^{\circ} \mathrm{C}$. Based on this assumption, calculated reservoir temperatures for the six hot waters range from $135^{\circ}$ to $196^{\circ} \mathrm{C}$, assuming only conductive heat loss in the rising thermal waters, and from $130^{\circ}$ to $179^{\circ} \mathrm{C}$, assuming single-stage steam loss at the surface temperatures of the hot waters. The two lowest values in each case are for the Liskey and Osborn hot wells in the Klamath Hills. Values for the Olene Gap and Klamath Falls samples range from $179^{\circ}$ to $196^{\circ} \mathrm{C}$ for the conductive model.

These estimates of reservoir temperature are clearly at variance with the estimates derived from concentrations of silica and water-oxygen isotopes (table 7) and explanations for the discrepancy must be sought. Two types of explanations can probably be discarded immediately. The bulk of the chemical and isotope data favors the concepts of low reservoir temperatures and largely undiluted thermal waters. Any explanation for the high sulfate-oxygen temperatures involving dilution of the thermal waters, therefore, would not only be opposed by this evidence but would also tend to increase the apparent reservoir temperatures and widen the gap between the estimates. Furthermore, the concept of mixing and dilution by nonthermal waters is 
also opposed by the fact that ${ }^{18} \mathrm{O}\left(\mathrm{SO}_{4}\right)$ concentrations are independent of chloride concentrations in the thermal waters. Explanations involving the solution of gypsum from shallow evaporite deposits may also be ruled out, inasmuch as the sulfate from such deposits would have high oxygen-isotope concentrations that would result in lower apparent reservoir temperatures.

One possible explanation for the high reservoir temperatures estimated from the sulfate-oxygen isotope could involve the formation of isotopically light $\mathrm{SO}_{4}$ in volcanic rocks during their emplacement at high temperatures. This $\mathrm{SO}_{4}$, taken into solution by geothermal waters circulating in faults of much later origin, would react with the lower-temperature thermal water in a process that possibly has not yet reached equilibrium at the low indicated temperatures. Although this explanation could account for the shift toward the observed isotope concentrations, it is somewhat unsatisfactory in that it requires the presence of hightemperature sulfate-bearing minerals which are not prevalent in volcanic rocks.

A second speculative explanation is that the sulfate-oxygen isotope has equilibrated in a deep reservoir that underlies the shallower zone tapped by thermal wells and springs. Hot water, presumably at or above the temperatures indicated by the sulfateoxygen geothermometer, rises into the shallow, cooler reservoir where most constituents, including silica, equilibrate at the lower temperatures. The sulfateoxygen isotope fails to attain equilibrium with the water-oxygen isotope in this reservoir as the waters rise more quickly along faults and fractures in the shallow geothermal system. Calculations based on expressions given by McKenzie and Truesdell (1977) show that complete equilibration at $150^{\circ} \mathrm{C}$ would require more than 77 years.

A completely satisfactory explanation of the discrepancy between the estimated reservoir temperatures is not available, and, therefore, no final conclusion has been reached in this study. The phenomenon described here is similar, however, to others observed in lowtemperature thermal waters in the High Cascades and in the Gila River area of Arizona where high sulfateoxygen isotope temperatures are also indicated $(\mathrm{R} . \mathrm{H}$. Mariner, oral commun., 1979). These discrepancies will apparently require further study of the chemical relations in thermal waters derived from thick volcanic sequences such as those at Klamath Falls and the areas mentioned above.

Three additional waters analyzed for ${ }^{18} \mathrm{O}\left(\mathrm{SO}_{4}\right)$ (table 8 ) are warm waters from the Klamath Hills. Results of these analyses, which show high concentrations of ${ }^{18} \mathrm{O}\left(\mathrm{SO}_{4}\right)$, further confirm the belief that the waters are mixtures containing evaporation residues. Estimates of reservoir temperature have not been made for these waters.

\section{TEMPERATURE DISTRIBUTION AND HEAT FLOW}

\section{AREAL DISTRIBUTION OF TEMPERATURE}

The distribution of temperature measured in ground water of the Klamath Falls area is shown on plate 3 . The isotherms of the map are generalized from data that have considerable scatter in many areas. Much of the scatter is due to differences in temperature between deep wells and shallow wells in the same area, the deeper wells having generally higher temperatures. The isotherms, therefore, are at best a rough guide to areas where wells of moderate depth (generally 150 to 500 feet) may be expected to encounter water with temperatures similar to those indicated by the contours.

The map shows that although warm water occurs at a large number of isolated places, it is found principally within the three closed $60^{\circ} \mathrm{C}$ contour lines that contain the Klamath Falls urban area, Olene Gap, and the southwest flank of the Klamath Hills.

\section{VERTICAL DISTRIBUTION OF TEMPERATURE}

Temperature profiles measured in 41 unused, nonflowing wells and two test holes are shown on plate 4 . The locations of these holes are shown in figure 13, and data pertaining to the profiles are given in table 10 where the profiles have been divided into three groups on the basis of their dominant characteristics: Mainly Conductive Profiles, Cold Convective Profiles, and Irregular Profiles.

Most of the wells in the first group, Mainly Conductive Profiles, penetrate fine-grained lacustrine sediments that range from silt and clay of Holocene age to shale and diatomite of the Pliocene Yonna Formation. Only three of the holes are known to penetrate basaltic rocks. The upper parts of the individual profiles are difficult to trace on plate 4 , but nearly all show evidence of downward convective transport in the upper tens of feet. In addition, many have temperature irregularities at depths that, in some instances, correspond to known permeable zones in the rocks.

Thermal gradients in the conductive profiles are generally high, ranging from $50^{\circ}$ to $180^{\circ} \mathrm{C}$ per kilometer $\left({ }^{\circ} \mathrm{C} \mathrm{km}^{-1}\right)$, even though temperatures are relatively low. The highest temperature observed is $38^{\circ} \mathrm{C}$ at 500 feet in CW 3, located at 39/9-3ddd, just south of Altamont.

The second category in table 10, Cold Convective Profiles, includes 10 wells characterized by low tem- 


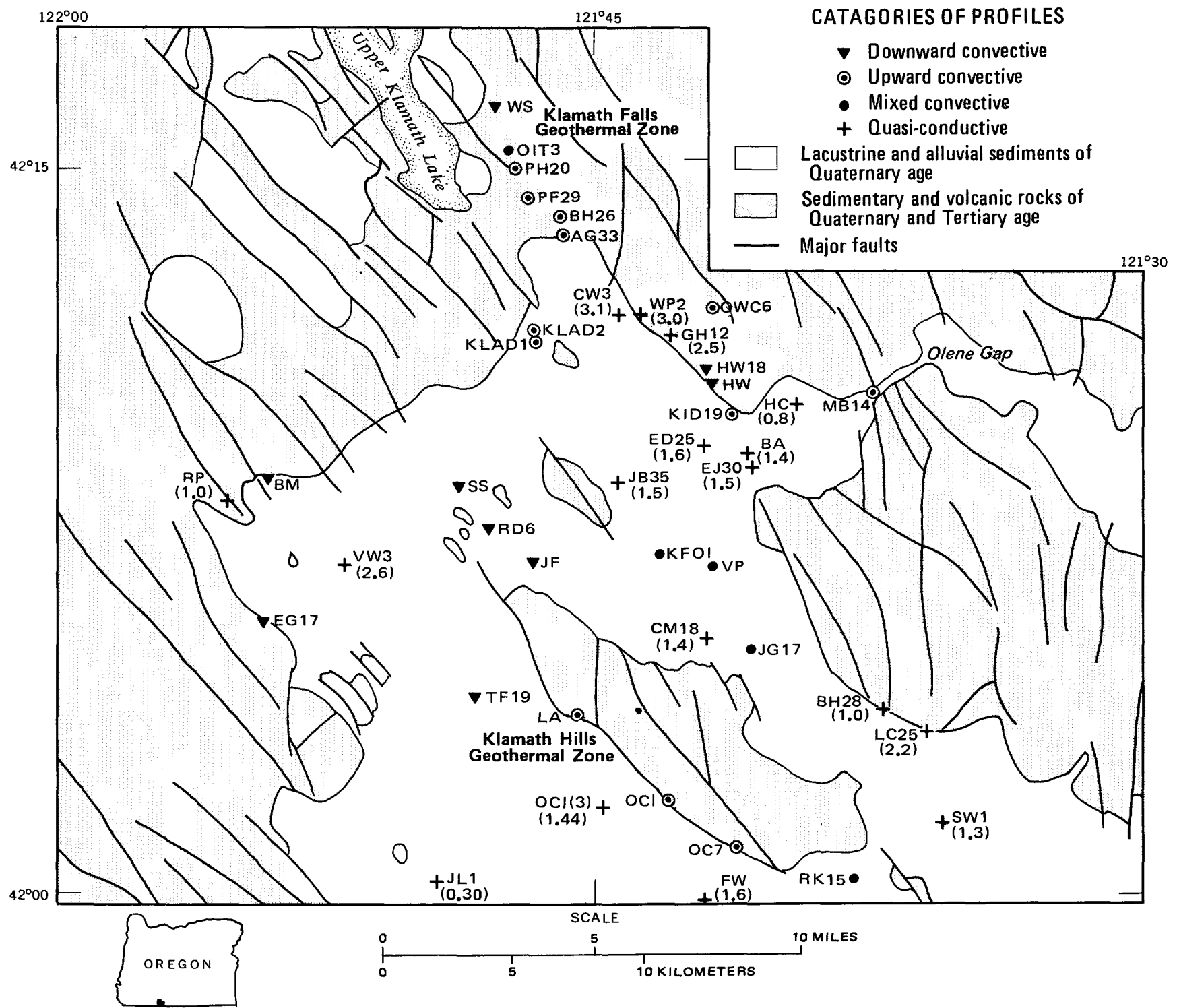

FIgURE 13.-Geologic sketch map of the Klamath Falls area (after Peterson and McIntyre, 1970), showing locations and categories of wells in which temperature profiles were obtained. For wells with quasiconductive (linear) profiles, a lower limit of heat flow, based on an assumed thermal conductivity of $1.8 \mathrm{mcal} \mathrm{cm}^{-1} \mathrm{~s}^{-1} \mathrm{C}^{-1}$, is shown in parentheses. Heat-flow determinations at JL1 and OC1(3) are also shown. (Adapted from Sass and Sammel, 1976.)

peratures and small thermal gradients. Most of these wells are located in the lowlands of the area and are relatively shallow. The profiles show that downward flow of cool water occurs to depths of 300 feet at places, indicating that the lake-bed sediments are relatively permeable at these locations.

Most of the areas dominated by convective flow and cold water are ground-water recharge areas. Significant amounts of recharge may also occur elsewhere as indicated by profiles that, although they are dominantly conductive, show evidence of downward circulation in their upper 50 to 100 feet. An example is the U.S. Geological Survey test hole, OC1 (3).
One of the deeper wells, OIT 3, shows downward convection to a depth of more than 900 feet. This well, with a maximum temperature of $28^{\circ} \mathrm{C}$, is located less than 2000 feet from one of the three hot wells at the Oregon Institute of Technology (fig. 4). The temperature difference between these wells (about $60^{\circ} \mathrm{C}$ ) and the difference in static water levels (210 feet) demonstrate the profound effect exerted by local structure and stratigraphy on subsurface temperatures and ground-water regimes.

The third category in table 10, termed "Irregular," includes all hot wells in which profiles were obtained as well as several cold wells. Most of these wells penetrate basalt flows of the Yonna Formation; two of them, 
TABLE 10.-Data related to temperature profiles obtained in unused wells and heat-flow holes

[*Gradient used in heat-flow calculations. See text for explanation]

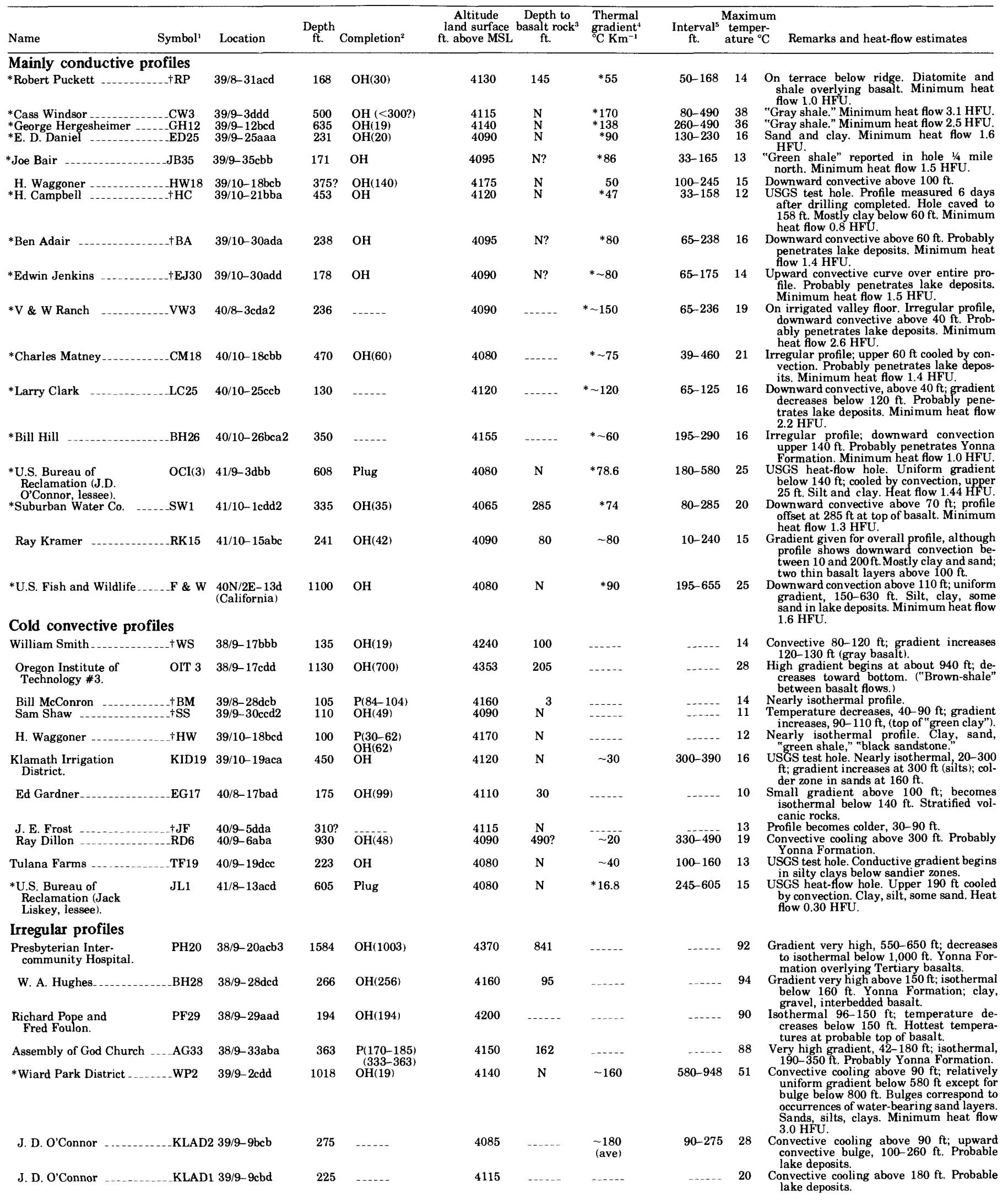


TABLE 10.-Data related to temperature profiles obtained in unused wells and heat-flow holes-Continued

\begin{tabular}{|c|c|c|c|c|c|c|c|c|c|}
\hline Symbol' & Location & $\begin{array}{l}\text { Depth } \\
\mathrm{ft} .\end{array}$ & Completion $^{2}$ & $\begin{array}{c}\text { Altitude } \\
\text { land surface } \\
\text { ft. above MSL }\end{array}$ & $\begin{array}{l}\text { Depth to } \\
\text { basalt rock } \\
\text { ft. }\end{array}$ & $\begin{array}{l}\text { Thermal } \\
\text { gradient } \\
{ }^{\circ} \mathrm{C} \mathrm{Km}^{-1}\end{array}$ & $\begin{array}{c}\text { Interval } \\
\mathrm{ft} .\end{array}$ & $\begin{array}{l}\text { Maximu } \\
\text { temper } \\
\text { ature }{ }^{\circ} \mathrm{C}\end{array}$ & Remarks and heat-flow estimates \\
\hline Oregon Water Corp. & $39 / 10-6 c \mathrm{db}$ & 732 & $\mathrm{OH}(147)$ & 4310 & 152 & $-\ldots$ & $-\cdots-$ & 33 & $\begin{array}{l}\text { Very low gradients above } 520 \mathrm{ft} \text {; warm } \\
\text { bulge below } 520 \mathrm{ft} \text {; nearly isothermal, } \\
700-730 \mathrm{ft} \text {. Top of basalt layer at } 514 \mathrm{ft} \text {. }\end{array}$ \\
\hline Marion Barnes _....... MB14 & $39 / 10-14 \mathrm{ccb}$ & 380 & $\mathrm{OH}(41)$ & 4120 & $22 ?$ & -60 & $280-380$ & 55 & $\begin{array}{l}\text { Very high gradient above } 190 \mathrm{ft} \text {. Water- } \\
\text { bearing sands in "green claystone" ac- } \\
\text { count for bulges below } 190 \mathrm{ft} \text {. }\end{array}$ \\
\hline Klamath Falls Oil Co. \#1 _ KF01 & $40 / 9-2$ daa2 & 1965 & $-\cdots$ & 4125 & $600 ?$ & $\sim 70$ & $120-620$ & 31 & $\begin{array}{l}\text { Basalt reported at } 600 \mathrm{ft} \text { (questionable- } \\
\text { may be Yonna Formation). Neariy } \\
\text { isothermal, } 740-1,320 \mathrm{ft} \text {. }\end{array}$ \\
\hline Leon Andrieu & $40 / 9-28 a d b$ & 128 & $\mathrm{OH}(23)$ & 4120 & $N$ & $-\ldots$ & $-\cdots$ & 15 & $\begin{array}{l}\text { Convective cooling to } 60 \mathrm{ft} \text { (water-bearing } \\
\text { gravel); top of conductive gradient in } \\
\text { "shale." }\end{array}$ \\
\hline Vern Peugh ......... & $40 / 10-6 \mathrm{cca}$ & 120 & $\mathrm{OH}(31)$ & 4080 & $\mathbf{N}$ & $\cdots$ & $-\ldots$ & 13 & $\begin{array}{l}\text { Convective cooling, upper } 40 \mathrm{ft} \text {; gradient } \\
\text { increases, top of "blue-green clay" at } 110 \\
\mathrm{ft} \text {. Sand and clay. }\end{array}$ \\
\hline Joe Glodoski _ & $40 / 10-17 \mathrm{ccb}$ & 189 & $\mathrm{OH}(60)$ & 4075 & $\mathbf{N}$ & $\ldots$ & $\ldots$ & 15 & $\begin{array}{l}\text { Convective cooling, upper } 50 \mathrm{ft} \text {; gradient } \\
\text { decreases in blue clay (60-160 ft); } \\
\text { isothermal in coarse to fine sand }(160- \\
189 \mathrm{ft}) \text {. }\end{array}$ \\
\hline O'Connor Livestock Co. _._. OC1 & $41 / 9-1 \mathrm{bcd}$ & 105 & ----- & 4155 & $-\ldots$ & -n-- & $-\cdots$ & 19 & $\begin{array}{l}\text { Convective cooling above } 60 \mathrm{ft} \text {. Probably } \\
\text { Yonna Formation }\end{array}$ \\
\hline O'Connor Livestock Co. _._._OC7 & $41 / 10-7 \mathrm{dba}$ & 770 & $\mathrm{OH}(79)$ & 4120 & 674 & $-\ldots-$ & ----- & 30 & $\begin{array}{l}\text { Moderately high gradient to } 100 \mathrm{ft} \text { ("hard } \\
\text { green shale, water-bearing"); isothermal, } \\
100-490 \mathrm{ft} \text { ("hard green shale" and } \\
\text { "green clay"). }\end{array}$ \\
\hline
\end{tabular}

'Location on plate 3 and profile on plate 4 identified by this symbol, $\uparrow$ Shallow, cold well, not identified on plate 4

${ }^{2} \mathrm{OH}=\mathrm{Open}$ hole below depth given ( $\mathrm{ft}$.); $\mathrm{P}=$ Perforated in interval given ( $\mathrm{ft}$ ).

${ }^{3}$ From driller's log; $\mathrm{N}=$ Not encountered.

'In general, the maximum gradient measurable over a significant depth interval; in wells designated by *, the conductive gradient for the given interval.
'Interval over which thermal gradient was determined.

PH 20 and OWC 6, also penetrate older Tertiary basalt.

Three irregular profiles in the upper right corner of plate 4 probably represent conditions at many places in and near the principal geothermal areas. These profiles, $\mathrm{PF} 29, \mathrm{BH} 28$, and AG 33, show typically high thermal gradients through relatively impermeable shale and clay of the Yonna Formation. Beneath these zones of high gradient, the profiles became isothermal in layers of permeable basalt and volcanic sediments. Profiles such as these suggest that hot water moves laterally in the permeable basalt layers and that this lateral movement may account for the widespread distribution of warm ground water in places such as the lowlands south of Klamath Falls and Altamont.

Most hot wells in the vicinity of Klamath Falls and Olene Gap have irregular but generally convexupward temperature profiles. To the extent that these profiles represent formation temperatures they indicate that both upward and lateral convective transport of heat occur in the aquifers. It is assumed that wells penetrating the Yonna Formation in the Klamath Hills geothermal area would show similar profiles. On the basis of the temperature profiles and the known discharge of thermal waters, these three areas are believed to be the principal thermal discharge areas.

In the foregoing discussion it is tacitly assumed that the temperature profiles measured in most wells represent temperatures in formations surrounding the wells. Some of the data make it clear, however, that many profiles do not accurately represent formation temperatures. Discrepancies between temperatures measured in wells and actual formation temperatures are usually due to one or both of two common occurrences: vertical convective flow in the well itself, and in cased wells, vertical flow in the annular space between the casing and the formation. Such vertical flow occurs in response to both temperature gradients and hydraulic gradients in the formation penetrated by the wells.

An isothermal profile caused by convective flow was measured in well OC 7 (pl. 4). The temperature profile in this uncased well is isothermal at $30^{\circ} \mathrm{C}$ between depths of 120 and 500 feet, the greatest depth to which measurements were made. Subsequently, when the well was pumped, the temperature of the water was found to be $37^{\circ} \mathrm{C}$. It is likely, therefore, that under nonpumping conditions, water with a temperature of about $30^{\circ} \mathrm{C}$ enters the well at shallow depths and flows downward with sufficient velocity to maintain an isothermal profile. Thus, temperature gradients measured in this well have little relation to geothermal gradients in the formation.

A second example can be seen by comparing temperature profiles obtained in two of the deepest wells in the area, PH 20 (1,584 feet) and OIT 6 (1,805 feet). These wells are located about 500 feet apart and drillers' logs indicate that they penetrate the same formations. The temperature gradient measured in well $\mathrm{PH} 20$, however, ranges from $330^{\circ} \mathrm{C} \mathrm{km}^{-1}$ at about 575 feet depth to nearly isothermal at 1,475 feet, whereas the gradient calculated from the bottom-hole measurements in OIT 6 over the same interval is more nearly uniform at about $180^{\circ} \mathrm{C} \mathrm{km}^{-1}$. The bottom-hole measurements are believed to provide a good estimate 
of the actual thermal gradient at this location in spite of small errors in absolute temperature that may have been introduced by the cable-tool drilling. Therefore, both the high gradient and the nearly isothermal gradient measured in PH 20 are almost certainly the products of convection in the well and are not reliable measures of gradients in the formation.

It is of interest to note also that the position of the sharp break in bottom-hole temperatures in the profile of OIT 6 near the 1,740 foot depth (pl. 4) corresponds to that of a gravel layer between basalt flows noted in the driller's log. The thermal discontinuity is probably due to the rapid movement of lower-temperature water through the gravel layer. Small lithologic and thermal discontinuities of this kind are difficult to detect in temperature profiles obtained in water wells, but they may strongly affect the measured geothermal gradients at some places.

Several examples of stratigraphic discontinuities were obtained in the temperature profiles. Wells OIT 3 , OWC 6, and MB 14 had lower temperatures when pumped than the maximum temperatures measured under static conditions. These wells appear to derive much of their discharge from cool strata at fairly shallow depths. The decreases in temperature observed during pumping may be taken as evidence of low vertical permeabilities in the formations and the stratification of the thermal and nonthermal waters at these locations.

The examples cited are believed to represent conditions that occur widely in the shallow hydrothermal system at Klamath Falls. They illustrate the difficulties that may be encountered in attempts to obtain reliable geothermal gradients in holes not especially constructed for this purpose, and they serve as a caution that the thermal gradients reported in this study should not be used uncritically in evaluating geothermal prospects in the area.

\section{CONDUCTIVE HEAT FLOW}

Two 600-foot holes were drilled by the Geological Survey in the Lower Klamath Lake area in order to obtain heat-flow information. These holes and the data obtained from them are described in detail in Sass and Sammel (1976). The temperature profiles from these holes are shown on plate 4 . The first hole, JL 1 , is on reclaimed marsh land in Lower Klamath Lake near the California border at T41, R8, Sect 13 acd. The hole penetrates lacustrine silt and clay to a depth of 605 feet. The mean thermal conductivity of cores from the hole is $1.82 \mathrm{mcal} \mathrm{cm}^{-1} \mathrm{~s}^{-1}{ }^{\circ} \mathrm{C}^{-1}$. For the interval between 167 and 587 feet the average gradient is about $16.75^{\circ} \mathrm{C}$ $\mathrm{km}^{-1}$. The heat flow at the site, therefore, is calculated to be 0.30 heat flow units (HFU).
The second hole OC 1 (3), was drilled at a location northeast of JL 1 , about 1 mile southwest of the Klamath Hills. For this hole, the mean thermal conductivity is $1.83 \mathrm{mcal} \mathrm{cm}^{-1} \mathrm{~s}^{-1}{ }^{\circ} \mathrm{C}^{-1}$, the temperature gradient in the interval 174 to 577 feet is $78.6^{\circ} \mathrm{C} \mathrm{km}^{-1}$, and the heat flow, therefore, is $1.44 \mathrm{HFU}$.

The heat flow calculated for hole JL $1(0.30 \mathrm{HFU})$ is too low to represent actual heat loss from the earth's interior over a broad area. Convective cooling by recharge of ground water to depths greater than 600 feet must be invoked in order to explain the observed heat flux, which, in the light of data discussed below, may be anomalous, even for the supposed recharge areas of Lower Klamath Lake.

Heat flow in the second hole, OC 1 (3), (1.44 HFU), is near the expected lower limit for conductive heat flow in the Basin and Range province (Sass and others, 1971). Data obtained from other conductive temperature profiles in the area suggest that hole OC 1 (3) probably represents near-normal conductive heat flow over much of the Lower Klamath Lake basin. The basis for this conclusion is discussed in the following paragraphs.

A possible range of heat-flow values in the Lower Klamath Lake basin was determined by using temperature gradients from 15 conductive temperature profiles obtained in the basin (table 10). These gradients were combined with the mean thermal conductivity determined for heat-flow holes JL 1 and OC 1(3), which is believed to be a representative value for much of the lower basin. Each of the wells in which these profiles were obtained penetrates unconsolidated to semiconsolidated lacustrine deposits in the Lower Klamath Lake valley. The resulting estimates of heat flow (table 10) are regarded as minimum values for the sites.

Calculated heat flows for the 15 wells range from 0.8 to $3.1 \mathrm{HFU}$, with the highest values coming from wells nearest the Klamath Falls and Olene Gap thermal areas. Seven of the wells in the southern part of the valley appear to represent average conditions over a wide area. Heat flows calculated for these wells range from 1.3 to $1.6 \mathrm{HFU}$. The calculated heat flow for OC $1(3), 1.44 \mathrm{HFU}$, therefore appears to represent nearnormal heat flow over much of the Lower Klamath Lake graben.

The wide range of the estimated minimum heat flows for the remainder of the wells $(0.8$ to $3.1 \mathrm{HFU})$ tends to confirm the conclusion, based on variations in the temperature profiles, that localized geologic and hydrologic conditions determine the temperature regime at most places. Many of the higher temperatures attained in the profiles appear to be caused by the insulating effect of poorly conductive unconsolidated deposits overlying basalt aquifers. Others are apparently influenced by 
lateral convective flow of heat and water in permeable zones within the basalt sequences. In general, the observed temperature profiles do not provide reliable estimates of regional temperature gradients and regional heat flux for areas outside the Lower Klamath Lake basin.

\section{CONVECTIVE DISCHARGE OF HEAT}

Estimates of heat discharged from springs and hot wells in the three principal geothermal areas have been calculated from measured and estimated ground-water discharge at land surface. An average base temperature of $12^{\circ} \mathrm{C}$ is assumed for ground water near the land surface. Results are given in table 11.

In the absence of detailed studies, the estimate of spring discharge into Upper Klamath Lake is little more than a guess. The remainder of the figures in table 11 are probably reasonable approximations in the light of presently available data.

Heat discharged at the water table or by the mixing of thermal and nonthermal ground water in the vicinity of the three geothermal areas would probably add large heat fluxes to those listed in table 11. In assessing this thermal discharge, one may compare the temperature distribution shown on plate 3 with the contour map of the shallow ground-water surface (pl. 1). In the vicinity of Klamath Falls, for example, shallow ground water apparently flows from the highlands surrounding the city, traverses the zone of highest temperatures, and flows southward across the valley floor into an area where ground-water gradients are very low. The temperature contours sugge st that the thermal waters mix and cool rapidly in the immediate vicinity of the principal thermal area and that slow convective upwelling and additional cooling occur in an extended area to the south.

This simple conceptual model is undoubtedly complicated in actuality by the stratified flow of hot water in basalt layers in the Yonna Formation. The general patterns of fluid flow and thermal mixing postulated above, however, are in accord with the evidence of the chemical data, and these convective flow patterns are believed to occur in the vicinity of each of the three principal thermal areas.

Because the patterns of lateral and vertical convection are complex in detail and are not well known, it is not possible to make a reliable estimate of the total convective heat discharge. On the basis of several reasonable assumptions, however, a crude estimate has been made of probable upper and lower limits for the total heat discharged by convective flow. For this estimate, it is assumed that ground-water flow within 500 feet of land surface in the vicinity of the geothermal areas occurs mostly in the Yonna Formation. The
TABLE 11.-Mass and thermal-energy discharge in ground water from thermal springs and wells in the Klamath Falls area

\begin{tabular}{|c|c|c|}
\hline & $\begin{array}{l}\text { Mass flow } \\
\left(\text { gal d d }^{-1}\right)\end{array}$ & $\begin{array}{l}\text { Thermal energy' } \\
\left(10^{5} \text { cal s}^{-1}\right)\end{array}$ \\
\hline Springs & & \\
\hline Olene Gap & 30,000 & 1.2 \\
\hline Eagle Point and Upper Klamath Lake. ${ }^{2}$ & $-.43,000$ & .4 \\
\hline \multicolumn{3}{|l|}{ Wells } \\
\hline $\begin{array}{l}\text { Residences, schools, and commercial } \\
\text { establishments. }\end{array}$ & _895,000 & 18.1 \\
\hline $\begin{array}{l}\text { Klamath Hills (irrigation and stock } \\
\text { wells) }\end{array}$ & $-1,900,000$ & 1.8 \\
\hline Totals & $2,868,000$ & 21.5 \\
\hline
\end{tabular}

'Heat discharge above datum of $12^{\circ} \mathrm{C}$ assumed for shallow ground water.

'Spring discharge into Upper Klamath Lake estimated by observation of winter thawing of lake surface. Estimate not reliable.

${ }^{3}$ Based in part on numbers of wells, flow rates, and temperatures described by Lund, Culver, and Svanevik, 1974.

transmissivity of the aquifer is estimated to be in the range 1,000 to $5,000 \mathrm{ft}^{2} \mathrm{~d}^{-1}$. Total length of the three thermal discharge areas is probably greater than 3 and less than 5 miles, and the ground-water gradients away from these discharge areas may range from 20 to $50 \mathrm{ft} \mathrm{mi}^{-1}$. Assuming, finally, that ground-water temperature decreases from 95 to $12^{\circ} \mathrm{C}$, convective heat dissipated in the shallow ground-water body or discharged at the water table is calculated to be in the range $2 \times 10^{6}$ to $30 \times 10^{6} \mathrm{cal} \mathrm{s}^{-1}$. Combining these figures with the estimate of thermal flow from springs and wells (table 11), the total convective flux in the vicinity of Klamath Falls is estimated to be in the range $4 \times 10^{6}$ to $32 \times 10^{6} \mathrm{cal} \mathrm{s}^{-1}$.

The range of values given above may be compared with an estimate of geothermal heat being utilized at present for space heating and other purposes. Lund and others $(1978$, p. 45$)$ estimate that about 6 megawatts per year $\left(1.4 \times 10^{6} \mathrm{cal} \mathrm{s}^{-1}\right)$ are currently utilized in some manner. The geothermal heat actually used is, therefore, a small fraction of the heat now being discharged by natural or artificial means in the Klamath Falls area.

\section{INTERPRETATIONS AND CONCLUSIONS}

\section{REVIEW OF EVIDENCE RELATING TO THE GEOTHERMAL RESOURCE}

\section{GEOLOGIC EVIDENCE}

Known geothermal reservoirs in the Basin and Range province appear to attain their high temperatures in two ways: (1) by conduction of heat from a magma body emplaced at fairly shallow depths, and (2) by circulation of ground water to depths at which the normal thermal gradient in crustal rocks provides the required temperatures. These two mechanisms may exist in combination. 
At most places where the first of these two mechanisms provides heat for known geothermal systems, the magma bodies are composed of silicic melts, often of crustal origin, that are both large enough and young enough to retain significant amounts of heat at the present time.

In southeastern Oregon, silicic volcanic activity has occurred during the last 10 million years in a westward-trending progression which culminated in the extrusion of rhyolitic domes and obsidian flows at Newberry Volcano, near Bend (MacLeod and others, 1975). The youngest silicic volcanic rocks at this location are less than 10,000 years old. In the Klamath Falls area, however, no silicic volcanic rocks occur at the surface and none has been penetrated by wells. When the trends of silicic volcanic activity in southeastern Oregon are extrapolated into the Klamath Falls area these trends suggest that if silicic intrusives existed, they would probably be about 4 million years old. On the basis of calculations made for the Long Valley, California, geothermal area (Lachenbruch and others, 1976), it is concluded that 4-million-year-old buried domal masses of average size would have cooled to near ambient temperatures by the present time. Thus, the available geologic evidence makes it appear improbable that the geothermal system at Klamath Falls is heated by silicic intrusive rocks, although this possibility is not ruled out.

Young volcanic rocks in the Klamath Falls area, some of them dating from late Pleistocene time, are of basaltic composition. At depth they probably occur as dikes and plugs in conduits that formerly conducted basaltic magma to eruptive centers and flow vents. These conduits probably extend deep into the crust, but there is little likelihood that they contain hightemperature rocks at depths shallow enough to be reached by circulating ground water.

The second of the two processes by which geothermal fluids are heated, circulation of ground water to great depths in a temperature field created by the earth's geothermal gradient, requires the presence of permeable channels through which flow can occur. The large Basin and Range faults that bound the Klamath Falls graben could provide the required channels as similar faults are assumed to do elsewhere in the Basin and Range province (White, 1968; Olmsted and others, 1975). The depth that would have to be reached by the Klamath Falls thermal waters in order to attain a temperature of $150^{\circ} \mathrm{C}$ is 15,000 feet if the geothermal gradient is as low as $30^{\circ} \mathrm{C}$ per kilometer. If the gradient is higher, as would be expected if rocks of low thermal conductivity overlying the reservoir created a blanketing effect, required depths would be smaller. Evidence from earthquakes in southeastern Oregon (Couch and
Lowell, 1971) suggests that faults in this area may extend to depths far greater than 15,000 feet, and it is probable, therefore, that these faults and associated fracture zones form the channels in which the Klamath Falls thermal waters circulate.

\section{GEOPHYSICAL EVIDENCE}

Temperature measurements in springs, wells, and test holes provide the only direct geophysical evidence relating to the geothermal resource at Klamath Falls. The temperature measurements show that, although warm ground water occurs throughout the lower Klamath Lake valley, hot water $\left(>60^{\circ} \mathrm{C}\right)$ is discharged principally in three elongate zones associated with major faults. Hot water may also be discharged from concealed faults beneath the lacustrine deposits of both upper and lower Klamath Lake valleys, and the presence of water with temperatures greater than $30^{\circ} \mathrm{C}$ at a few places in the Lower Klamath Lake valley may be evidence of this occurrence (see pl. 3).

Temperature gradients observed in water wells are generally higher near the principal geothermal areas than elsewhere, but few of these gradients are reliable indicators of crustal temperature regimes. Most of the temperature profiles obtained for this study are strongly affected by the convective transfer of heat in moving ground water and hence cannot be used for estimates of conductive heat flow.

A few conductive thermal gradients obtained in the Lower Klamath Lake Basin suggest that heat flow through the lake sediments may be on the order of $1 \frac{1}{2}$ HFU. This value is at the low end of expected values for the Basin and Range province. Although this evidence cannot be considered highly reliable, it greatly decreases the probability that a source of magmatic heat exists at shallow depth beneath the Lower Klamath Lake graben. Temperature measurements from the upper Klamath Lake basin and from the upraised blocks surrounding the basins are too scanty to permit conclusions regarding possible magmatic sources of heat in these areas.

Indirect geophysical evidence obtained from gravity and aeromagnetic surveys has been described and interpreted by D. L. Peterson in a previous report (Peterson, 1976). In general, the gravity and aeromagnetic trends coincide with the dominant northwestsoutheast fault trend through the area. The data indicate that the lowlands are sunken blocks bounded by steeply dipping normal faults and covered by great thicknesses of low-density sediments. Gravity modeling suggests that the graben structure may be 3,000 feet deep in the area southeast of Klamath Falls and may be more than twice as deep southwest of Klamath Hills. 
The gravity data also indicate the presence of structures that may be only suspected from surficial evidence. Examples are a possible northeast-southwest trending fault passing through Olene Gap and an east-west trending fault near the north end of Upper Klamath Lake. A major gravity anomaly in the area southwest of Keno may be related to rocks of the adjacent eruption center. Of these anomalies, only the postulated fault through Olene Gap is related to known geothermal occurrences.

Peterson's interpretation of the aeromagnetic map indicates that most magnetic anomalies are related to the same structures that cause the gravity anomalies. For example, gravity and magnetic lows both occur in the deep structural depression in the Lower Klamath Lake basin. In addition, magnetic anomalies suggest the presence of buried basaltic rocks in the valley-fill deposits at Squaw Point in Upper Klamath Lake and at a location near Keno in Lower Klamath Lake.

The gravity and magnetic data suggest that subsurface structure exists at many places in marked contrast to the nearly featureless valley floor. Transecting faults apprently offset the basement topography in a pattern of tilted blocks which have a wide range of depths beneath the valley surface. Basalt flows intercalated in the valley-fill deposits add to the complexity of the geophysical patterns.

The hydrologic consequences of these discontinuities are many. Locally, the boundaries of the lithologic units may be relatively impermeable, thereby contributing to the segregation of waters of differing chemical quality. Elsewhere, basalt flows and fault zones may form distribution channels for thermal waters. These phenomena are not well known in detail, but they will have important consequences in the future if significant quantities of thermal water are withdrawn from and reinjected into the thermal reservoir.

\section{CHEMICAL EVIDENCE}

Hot waters from the three geothermal areas of Klamath Falls have similar, although not identical, chemical characteristics. The similarities suggest that the waters from the three areas have equilibrated in nearly identical rocks at similar depths and temperatures.

On the basis of the chemical data, the thermal waters appear to circulate in a hot-water system of moderate temperature $\left(<150^{\circ} \mathrm{C}\right)$. Ratios of boron and fluorine to chloride indicate that the water is heated mainly by conduction rather than by condensation of steam from an underlying vapor-dominated system. Hot water rising in the principal conduits probably cools largely by conduction, with little loss of volatile elements and little exchange of ions with the surround- ing rocks. Thus, the chemical compositions of the hotter waters observed at the surface may be closely similar to the compositions of water in the reservoir rocks.

Sources of the meteoric recharge waters and flow paths through the geothermal system have not been identified in this study, but the chemical data are consistent with the hypothesis that local ground water furnishes recharge for the system. Primary evidence for this hypothesis consists of similar concentrations of deuterium and similar ratios of $\mathrm{SO}_{4} / \mathrm{Cl}$ and $\mathrm{B} / \mathrm{Cl}$ in the hot and cold waters as well as expected changes in concentrations of sodium, chloride, sulfate, silica, and bicarbonate. Most shallow ground waters in the region have similar chemical compositions, and the available chemical analyses do not make it possible to distinguish separate recharge waters or reservoir waters.

Ratios of ionic constituents and concentrations of stable isotopes in the thermal waters are qualitative indicators of the probable range of reservoir temperatures at Klamath Falls. Application of the quartz geothermometer to mixing models based on silica and stable-isotope concentrations indicates that reservoir temperatures are greater than $145^{\circ} \mathrm{C}$, but the moderately high $\mathrm{Ca} / \mathrm{HCO}_{3}$ ratios, high $\mathrm{Na} / \mathrm{K}$ ratios, and the small shift of $\delta^{18} \mathrm{O}$ from the levels measured in local meteoric waters suggest that temperatures are probably not much higher than $150^{\circ} \mathrm{C}$.

The estimates of reservoir temperature derived from both silica and ${ }^{18} \mathrm{O}\left(\mathrm{H}_{2} \mathrm{O}\right)$ concentrations are reassuring in their general consistency and are supported by the patterns of ionic ratios in the thermal waters. These results must be weighed, however, against the higher estimates derived from ${ }^{18} \mathrm{O}\left(\mathrm{SO}_{4}\right)$ concentrations. (See section "Reservoir Temperature Estimated from Oxygen Isotopes in Dissolved Sulfate.") If the concentration of ${ }^{18} \mathrm{O}$ in dissolved sulfate is a reliable indicator, the thermal waters have, at some point in their history, equilibrated at temperatures that could have been as high as $196^{\circ} \mathrm{C}$ and were at least $180^{\circ} \mathrm{C}$.

Two possible models are offered in explanation of the high reservoir temperatures indicated by the sulfate oxygen isotope. In model (1), a two-stage reservoir is postulated, with the two stages separated in either space or time or both. In this model, ${ }^{18} \mathrm{O}\left(\mathrm{SO}_{4}\right)$ in deep thermal water is assumed to equilibrate with ${ }^{18} \mathrm{O}\left(\mathrm{H}_{2} \mathrm{O}\right)$ at temperatures greater than $190^{\circ} \mathrm{C}$ for a period of time which may be as long as several tens of years (McKenzie and Truesdell, 1977, p. 53). Other constituents, including silica, would also equilibrate at these temperatures. At some later time and at a shallower depth, the water re-equilibrates at lower temperatures, acquiring the chemical characteristics observed at the surface and leaving only the sulfate-oxygen isotope as a vestige of its former chemical state. In model (2), isotopi- 
cally light $\mathrm{SO}_{4}$ is formed in volcanic rocks during their emplacement at high temperatures. Subsequent exchange with circulating thermal waters tends to shift the ${ }^{18} \mathrm{O}\left(\mathrm{SO}_{4}\right)$ concentrations toward their equilibrium values at much lower temperatures in a process that is still incomplete.

These explanations are merely speculative and others undoubtedly are possible. Until such alternative explanations can be either confirmed or ruled out by additional evidence, the apparent high reservoir temperatures indicated by the sulfate-oxygen isotope should probably be viewed with scepticism in the light of the remainder of the chemical and isotope data.

Analysis of the stable-isotope concentrations suggests rather strongly that thermal waters in the three principal geothermal areas near Klamath Falls rise from three similar but distinct reservoirs. The oxygen and deuterium relations indicate separate sources of recharge for waters of the Klamath Falls hot-well area and those of Olene Gap, and the sulfate-oxygen geothermometer suggests yet a different history or origin for the Klamath Hills hot waters. Although these interpretations lack confirmation by other lines of evidence, they cast doubt on the existence of a single large reservoir beneath the Klamath Falls graben.

\section{CONCEPTUAL MODEL OF THE GEOTHERMAL SYSTEM}

The deep geothermal system at Klamath Falls has not been explored, and only near-surface indications and geophysical data provide indirect evidence of the nature of the system. Based on the evidence obtained during this study, a highly generalized conceptual model has been formulated. Verification and refinement of this model probably will require the acquisition of new data, and in particular, data from deep drill holes.

Geothermal phenomena at the earth's surface have the following fundamental causes: (1) the presence of an intrusive mass of molten or still hot rock; (2) high heat production from radiogenic sources; (3) convective transport of heat and fluids from depth in a cyclic system; and (4) the insulating effect of layers of rock having low thermal conductivities. Although each of these types of systems may produce high-temperature gradients near the earth's surface, only the first two are necessarily accompanied by higher than normal conductive heat flows. Most geothermal systems are produced by a combination of at least two of the possible causes.

On the basis of the evidence gathered during this study, the geothermal system at Klamath Falls is best explained as a convection system with deep circulation of meteoric water. Thus, the conceptual model proposed for this system is a fairly simple one. Meteoric water in the Tertiary basaltic rocks of the region is assumed to percolate downward along the vast network of faults and fracture zones that characterize the regional structure. After attaining depths on the order of 15,000 feet the temperatures of at least $150^{\circ} \mathrm{C}$, the water rises to shallow depths through conduits closely associated with major faults. If the two-stage reservoir postulated on the basis of sulfate-oxygen isotope data exists, the shallower of the two reservoir zones may occur at depths less than 10,000 feet. This zone may be supplied by slow upward leakage through a few conduits from depths as great as 15,000 to 20,000 feet.

The postulated depths are based on the assumption that geothermal gradients are uniform and are no greater than $30^{\circ} \mathrm{C} \mathrm{km}^{-1}$, a probable minimum value for the region. It is likely, however, that actual depths of circulation are less than those calculated above on the assumption of uniform thermal gradients in the crustal rocks. Normal heat flow in the Klamath Falls area is probably impeded by rocks of low thermal conductivity that overlie the sunken blocks in the Klamath Lake grabens. Within these grabens, isotherms are probably displaced upward, and assuming that offsetting thermal effects in adjacent upraised blocks are smaller than the insulating effect of the sunken blocks, temperature at a given depth will be higher than that predicted by a uniform normal gradient. The high thermal gradients (nearly $\left.80^{\circ} \mathrm{C} \mathrm{km}^{-1}\right)$ and low heat flows $(<1.5$ HFU) observed in the Geological Survey heat-flow hole, OC 1 (3), and in well FW in the Lower Klamath Lake basin are evidence for this concept.

Although the structural and lithologic conditions postulated above probably also exist in several of the basins adjacent to Klamath Falls, conditions for the upward flow of heated water presumably are especially favorable at Klamath Falls. These favorable conditions may include both the elevation of isotherms in a large volume of rock and the presence of relatively permeable flow channels in parts of the area. The faultrelated conduits that permit reasonably free convective flow of hot water at three separate locations in the vicinity of Klamath Falls may be vestiges of the extensive and active hot-water system that must have operated to silicify some thousands of cubic meters of rock during Pleistocene or earlier time.

At present, the rising hot waters are probably largely confined to conduits in the three principal geothermal areas, with only minor amounts of upward flow occurring in the interior of the valley. If conduits exist in concealed faults beneath the valley bottoms they may be effectively sealed off at most places by the fine-grained deposits that occupy the valleys.

Hot waters from the principal geothermal areas originate and equilibrate under generally similar res- 
ervoir conditions. Differing oxygen and deuterium isotope concentrations suggest, however, that the reservoir underlying the three areas is separated into at least three distinct zones. The boundaries of these postulated reservoir zones are unknown and their overall lateral extent can only be surmised from the extent of the surface phenomena. Based on surface manifestations, a single reservoir could extend over an area of at least 100 square miles. If, as seems more likely, the reservoir consists of more or less separate permeable zones, the total areal extent of these zones may be as small as 20 square miles.

Depth to permeable reservoir rocks beneath the valley floors may be as great as 6,000 feet based on inferred depths to basaltic rocks. In the upraised basaltic rocks adjacent to the valley, depth to areally extensive thermal reservoirs may be significantly smaller, perhaps no more than 2,000 or 3,000 feet at some places.

Most of the heated water rising from the reservoir does not reach land surface, but spreads through permeable zones in basaltic rocks beneath or within the Yonna Formation. In these strata, which occur at depths of a few tens of feet to at least 1,500 feet, the flow is predominantly lateral in response to local gradients in the shallow ground water reservoir. The hot water mixes with local meteoric water in these strata, and within a half mile of the major fault conduits, temperatures may decrease about $60^{\circ} \mathrm{C}$.

The spread of hot water near the geothermal areas produces notable effects on temperature gradients in these areas. Most thermal gradients measured in the Klamath Falls area represent only local perturbations in the normal geothermal gradient that occur as the result of convective transport of heat in moving ground water. Gradients may be extremely high $\left(>150^{\circ} \mathrm{C}\right.$ $\mathrm{km}^{-1}$ ) in impermeable rocks of the Yonna Formation where these rocks overlie basalt or permeable gravel bearing hot water. At other places where the Yonna Formation is more permeable, temperature profiles may be nearly isothermal, and gradients may even be reversed beneath hot-water zones. These phenomena are observed at depths as great as 1,800 feet (plate 4) and they probably persist to even greater depths in the principal geothermal areas.

The conceptual model described above suggests that heat flow may be generally low in the thick valley-fill deposits of the area as the result of the concentration of the regional heat flow in a few small areas. The relatively low estimated heat flow observed in the lower Klamath Lake basin may be evidence of this effect. The model also implies that heat flow may be disturbed on the periphery of the basin as the result of displacement of temperature contours within the basins. This effect is probably masked by topographic effects and by convective heat flow in the major geothermal areas; consequently, it may be difficult or impossible to detect.

As a rough check on the areal heat-flow balance, assume that the regional conductive heat flow is near the upper limit of normal values for the Basin and Range province, or about $2 \mathrm{HFU}$. Over the approximately 100 square miles of the Klamath Falls thermal area, total conductive heat flow is therefore calculated to be $5.2 \times$ $10^{6} \mathrm{cal} \mathrm{s}^{-1}$. This figure may be compared with an estimate given earlier which indicates that the total convective thermal discharge from the Klamath Falls thermal areas is probably in the range $4 \times 10^{6}$ to $32 \times$ $10^{6} \mathrm{cal} \mathrm{s}^{-1}$. According to these estimates, therefore, most of the normal heat flow through the crust in this area may be concentrated by convective discharge in the three geothermal areas. Uncertainty in the estimate of convective discharge is large, but even if the actual discharge were at the low end of the estimated range $\left(4 \times 10^{6} \mathrm{cal} \mathrm{s}^{-1}\right)$, the regional conductive heatflow patterns must be significantly altered by the convective discharge of heat at Klamath Falls. It is likely, therefore, that observations of heat-flow patterns within and adjacent to the Klamath Falls graben could provide a test of the conceptual model presented here.

Digital models may be used to obtain insight into permissible boundary conditions and heat-flow rates in the geothermal system. A model study for this purpose is currently (1979) underway in the USGS geothermal research program in Menlo Park. Results of this study will be presented in a subsequent report.

\section{RECHARGE TO THE GEOTHERMAL SYSTEM}

Postulated modes of recharge depend greatly on the assumed depth, nature, and extent of the geothermal reservoir. In the absence of definitive data on the reservoir, only general conclusions have been reached regarding the source and magnitude of recharge. Recharge may occur through the same fault systems that, at places, conduct the hot water to the surface, although it seems unlikely that downward flow would be confined to isolated channels as the thermal discharge appears to be. Rather, the recharge may occur as slow, diffuse seepage through extensive segments of the fault zones, perhaps at relatively great distances from the discharge sites.

Quantities of water available for recharge are large if the area of potential recharge is assumed to extend to a radius of, say, 25 miles from the center of the three geothermal areas. Over this area precipitation is about $2.4 \times 10^{6}$ acre- $\mathrm{ft} \mathrm{yr}^{-1}$, of which about $2.1 \times 10^{6}$ acre- $\mathrm{ft}$ $\mathrm{yr}^{-1}$ is lost through evapotranspiration. The remainder,

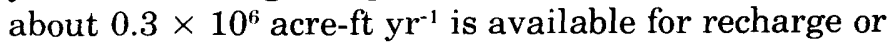


runoff. It is likely, of course, that only a small part of the potential recharge can be captured in the areas that directly feed the geothermal system.

Ground-water flow into the Lower Klamath Lake basin from upper basins may be as much as 170,000 acre-ft $\mathrm{yr}^{-1}$. If so, this flow would represent a major source of recharge to the geothermal reservoir. Because the Klamath Falls area is a large structural depression, shallow ground water may enter the area from all directions, although scanty observations suggest that there is an overall gradient through the area toward the southwest. A deep regional flow system could bring additional ground water into the area from the High Cascades, but there is no evidence to indicate whether or not such flow occurs.

\section{MAGNITUDE OF THE GEOTHERMAL RESOURCE}

On the basis of data available in early 1978 , Brook and others (1979) estimated the total heat content of geothermal systems at Klamath Falls within $3 \mathrm{~km}$ of the surface to be $33.1 \times 10^{18}$ joules $(\mathrm{J})$. The estimate was based on an assumed total reservoir volume of about $125 \mathrm{~km}^{3}\left(30 \mathrm{mi}^{3}\right)$ in two separate areas, Klamath Hills and Klamath Falls. The Klamath Falls area included the springs at Olene Gap. Employing the figures given by these authors for the probable maximum and minimum errors of estimate, the probable maximum heat content is calculated to be $49 \times 10^{18} \mathrm{~J}$ and the probable minimum heat content is $17 \times 10^{18} \mathrm{~J}$.

On the basis of additional temperature measurements, isotope mixing models, and differing estimates of reservoir volumes obtained in the present study, the writer has made new estimates of probable maximum and minimum heat contents. Unlike the previous estimates, which are based on differing mean reservoir temperatures for the Klamath Hills and the Klamath Falls systems $\left(124^{\circ} \mathrm{C}\right.$ and $111^{\circ} \mathrm{C}$, respectively), the present estimate assumes a single reservoir temperature for all systems $\left(150^{\circ} \mathrm{C}\right)$. This temperature represents a significant increase over those used previously, but it is clear from the calculations given below that the most significant parameters used in the estimation of heat content are those related to the volume of the reservoir, and, in particular, the estimates of area.

The probable maximum heat content is calculated by assuming that the reservoir is a continuous volume of basaltic rock in which hot water moves through fractures, permeable interflow zones, and fault zones. The reservoir is assumed to occupy an irregular but roughly rectangular area aligned northwest-southeast and extending from Upper Klamath Lake to the south end of the Klamath Hills, a distance of about 17 miles. The reservoir area is assumed to be bounded by the west face of Stukel Mountain and the west face of the Klamath Hills, to extend east into Olene Gap, and to narrow to about $2 \frac{1}{2}$ miles in the vicinity of the city of Klamath Falls. The total surface area is approximately $108 \mathrm{mi}^{2}\left(275 \mathrm{~km}^{2}\right)$.

Additional assumptions are as follows: (1) The reservoir temperature is $150^{\circ} \mathrm{C}$, or $138^{\circ} \mathrm{C}$ above a base temperature of $12^{\circ} \mathrm{C}$ assumed for shallow ground water in the region; (2) the reservoir is 6,600 feet $(2 \mathrm{~km})$ thick above a depth of 13,000 feet $(4 \mathrm{~km})$; and (3) the specific heat of the reservoir rocks is $0.6 \mathrm{cal} \mathrm{cm}^{-3}{ }^{\circ} \mathrm{C}^{-1}$, based on averages for crustal basaltic rocks (John Sass, oral commun., 1974). Combining these assumptions with the estimate of reservoir area given above, the heat content is calculated as follows:

$$
\begin{aligned}
\text { Heat content }= & 138\left({ }^{\circ} \mathrm{C}\right) \times 2(\mathrm{~km}) \times 10^{5} \frac{(\mathrm{cm})}{(\mathrm{km})} \\
& \times 0.6 \frac{(\mathrm{cal})}{\left(\mathrm{cm}^{3}\right)\left({ }^{\circ} \mathrm{C}\right)} \times 275\left(\mathrm{~km}^{2}\right) \times 10^{10} \\
\frac{\left(\mathrm{cm}^{2}\right)}{\left(\mathrm{km}^{2}\right)} & =46 \times 10^{18}(\mathrm{cal}) \times 4.184 \text { joules per } \\
= & \text { calorie } \\
= & 192 \times 10^{18} \mathrm{~J} .
\end{aligned}
$$

For an estimate of a probable minimum reservoir volume, it is assumed that the reservoir is confined to three separate elongate areas aligned with the main faults in the principal geothermal areas at Klamath Falls, Olene Gap, and the Klamath Hills. Widths of the areas range from 1 mile at Olene Gap and the Klamath Hills to $1 \frac{1 / 4}{4}$ miles at Klamath Falls. Lengths range from about $4 \frac{1}{2}$ miles at Olene Gap to $61 / 2$ miles at Klamath Falls and the Klamath Hills. The total surface area is about $19 \mathrm{mi}^{2}\left(50 \mathrm{~km}^{2}\right)$. It is further assumed that the reservoir is no more than 3,000 feet $(1 \mathrm{~km})$ thick. Thus, in this conceptual model, the reservoir is restricted to rocks immediately adjacent to the principal faults that conduct the hot waters to the surface. Total volume is assumed to be $12 \mathrm{mi}^{3}\left(50 \mathrm{~km}^{3}\right)$.

Based on the assumptions given above, and using the temperature and specific heat values employed for the previous estimate, the probable minimum amount of stored heat is calculated to be $3.5 \times 10^{18} \mathrm{cal}\left(14.6 \times 10^{18}\right.$ J).

The difference of an order of magnitude between the probable limits of reservoir volume given here reflects a serious deficiency in actual knowledge of subsurface conditions at Klamath Falls. The estimates can be regarded only as attempts to assign reasonable limits to the overall size and type of reservoir that might produce the observed geothermal phenomena. 
If the actual heat content were determined to be in the upper part of the estimated range, the geothermal reservoir at Klamath Falls would be among the largest nongeopressured reservoirs in the United States. If, as seems more likely, the reservoir at Klamath Falls comprises two or more permeable hot-water zones that are separated by relatively unproductive rocks, the total reservoir volume may be near the probable minimum estimate given above. A most likely range of heat content, therefore, may be two to three times the probable minimum, or $7 \times 10^{18} \mathrm{cal}$ to $10 \times 10^{18} \mathrm{cal}(30$ $\times 10^{18} \mathrm{~J}$ to $40 \times 10^{18} \mathrm{~J}$ ). Compared to heat contents estimated for other hydrothermal convection systems in the United States having temperatures near $150^{\circ} \mathrm{C}$, this is still an impressively large number.

The above estimates of heat content, based on the concept of deep convective flow, would not be changed by assuming the presence of a hot igneous mass at greater depth. Although the ultimate recoverability of geothermal heat and the methods of exploiting it would differ depending on whether a heat source were present or not, the total heat stored to depths of 10,000 feet or more may fall within the estimated limits in either case.

As is true for most low-temperature hydrothermal systems, utilization of the Klamath Falls geothermal resource for production of electrical power is not economically feasible under present conditions. Future utilization for any purpose will probably be highly sensitive to the actual nature and extent of the reservoir. The facts can be ascertained only by additional exploration, by the acquisition of more complete chemical and isotope data, and by subjecting the data to more sophisticated analysis. Exploratory drilling to depths of at least 6,000 feet will probably be required in order to provide definitive answers to the many questions that remain unresolved by this study.

\section{REFERENCES CITED}

Brook, C. A., Mariner, R. H., Mabey, D. R., Swanson, J. R., Guffanti, Marianne, and Muffer, L. J. P., 1979, Hydrothermal convection systems with reservoir temperatures $\geqslant 90^{\circ} \mathrm{C}$, in Muffler, L. J. P., ed., Assessment of geothermal resources of the United States1978: U.S. Geological Survey Circular 790, p. 18-85.

Couch, R. W., and Lowell, R. P., 1971 Earthquakes and seismic energy release in Oregon: The Ore Bin, v. 33, no. 4, p. 61-84.

Craig, H., 1961a, Isotopic variation in meteoric waters: Science, v. 133, p. 1702

$1961 \mathrm{~b}$, Standard for reporting concentrations of deuterium and oxygen-18 in natural waters: Science, v. 133, p. 1833.

Fournier, R. O., 1977, Chemical geothermometers and mixing models for geothermal systems: Geothermics, v. 5, p. 41-50.

Fournier, R. O., and Rowe, J. J., 1966, Estimation of underground temperatures from the silica content of water from hot springs and wet steam wells: American Journal of Science, v. 264, no. 9, p. 685-697.
Fournier, R. O., and Truesdell, A. H., 1973, An empirical Na-K-Ca geothermometer for natural waters: Geochimica et Cosmochimica Acta, v. 37, p. 1255-1275.

1974, Geochemical indicators of subsurface temperaturePart II, Estimation of temperature and fraction of hot water mixed with cold water: U.S. Geological Survey Journal of Research, v. 2, no. 3, p. 263-270.

Gilbert, G. K., 1928, Studies of Basin Range structure: U.S. Geological Survey Professional Paper 153, 92 p.

Hubbard, L. L., 1970, Water budget of Upper Klamath Lake, southwestern Oregon: U.S. Geological Survey Hydrologic Investigations Atlas HA-351.

Illian, J. R., 1970, Interim report on the ground water in the Klamath basin, Oregon: Salem, Oregon State Engineer, $110 \mathrm{p}$.

International Atomic Energy Agency, 1974, Symposium on isotope techniques in ground-water hydrology: Vienna, March 1974, Proc., 2 vols.

Lachenbruch, A. H., Jr., Sass, J. H., Munroe, R. J., and Moses, T. H., Jr., 1976, Geothermal setting and simple heat-conduction models for the Long Valley Caldera: Journal of Geophysical Research, v. 81, no. 5, p. 769-784.

Leonard, A. R., and Harris, A. B., 1974, Ground water in selected areas in the Klamath Basin, Oregon: Salem, Oregon State Engineer Ground Water Report No. 21, 104 p.

Lund, J. W., Principal Investigator, 1978, Geothermal hydrology and geochemistry of Klamath Falls, Oregon, urban area: Klamath Falls, Oregon Institute of Technology, Geo-Heat Utilization Center, Final report to the U.S. Geological Survey (Grant 1408-0001-G-291), $123 \mathrm{p}$.

Lund, J. W., Culver, G. G., and Svanevik, L. S., 1974, Utilization of geothermal energy in Klamath Falls: International Conference on Geothermal Energy for Industrial, Agricultural, and Commercial Uses, Klamath Falls, Oregon Institute of Technology, Proc., p. 146-178.

McKenzie, W. F. and Truesdell, A. H., 1977, Geothermal reservoir temperatures estimated from the oxygen isotope compositions of dissolved sulfate and water from hot springs and shallow drillholes: Geothermics, v. 5, p. 51-61.

MacLeod, N. S., Walker, G. W., and McKee, E. H., 1975, Geothermal significance of eastward increase in age of Upper Cenozoic rhyolitic domes in southeastern Oregon: U.S. Geological Survey Open-File Report 75-348, 22 p.

Mariner, R. H., and Willey, L. M., 1976, Geochemistry of thermal waters in Long Valley, Mono County, California: Journal of Geophysical Research, v. 81, no. 5, p. 792-800.

Meyers, J. D., and Newcomb, R. C., 1952, Geology and ground-water resources of the Swan Lake-Yonna Valley area, Klamath County, Oregon: U.S. Geological Survey Open-File Report, $151 \mathrm{p}$.

Moore, B. N., 1937, Nonmetallic mineral resources of eastern Oregon: U.S. Geological Survey Bulletin 875, 180 p.

Newcomb, R. C., 1958, Yonna formation of the Klamath River basin, Oregon: Northwest Science, v. 32, no. 2, p. 41-48.

Newcomb, R. C., and Hart, D. H., 1958, Preliminary report on the groundwater resources of the Klamath River basin, Oregon: U.S. Geological Survey Open-File Report, 248 p.

Olmsted, F. H., Glancy, P. A., Harrill, J. R., Rush, F. E., and Van Denburg, A. S., 1975, Preliminary hydrogeologic appraisal of selected hydrothermal systems in northern and central Nevada: U.S. Geological Survey Open-File Report 75-56, 267 p.

Oregon State Water Resources Board, 1971, Klamath Basin: Salem, Oregon, State Water Resources Board, 288 p.

Peterson, D. L., 1976, Preliminary interpretation of geophysical data, in Sammel. E. A., 1976, Hydrologic reconnaissance of the geothermal area near Klamath Falls, Oregon: U.S. Geological Survey Water Resources Investigations 76-127, p. A1-A10 
Peterson, N. V., and Groh, E. A., 1967, Geothermal potential of the Klamath Falls area, Oregon; a preliminary study: The Ore Bin, v. 29 , no. 11 , p. 209-231.

Peterson, N. V., and McIntyre, J. R., 1970, The reconnaissance geology and mineral resources of eastern Klamath County and western Lake County, Oregon: Portland, Oregon Department of Geology and Mineral Industries Bulletin 66, $70 \mathrm{p}$.

Renner, J. L., White, D. E., and Williams, D. L., 1975, Hydrothermal convection systems, in White, D. E., and Williams, D. L., eds., Assessment of Geothermal Resources of the United States1975: U.S. Geological Survey Circular 726, p. 5-57.

Russell, R. J., 1928, Basin Range structure and stratigraphy of the Warner Range, northeastern California: California University Publications in Geological Sciences, v. 17, no. 11, p. 387-496.

Sammel, E. A., 1976, Hydrologic reconnaissance of the geothermal area near Klamath Falls, Oregon: U.S. Geological Survey Water Resources Investigations 76-127, 129 p.

Sass, J. H., Lachenbruch, A. H., Munroe, R. J., Greene, G. W., and Moses, T. H., Jr., 1971, Heat flow in the western United States: Journal of Geophysical Research, v. 76, p. 6376-6413.

Sass, J. H., and Sammel, E. A., 1976, Heat-flow data and their relation to observed geothermal phenomena near Klamath Falls, Oregon: Journal of Geophysical Research, v. 81, no. 26, p. 4863-4868.

Taylor, H. P., Jr., 1974, The application of oxygen and hydrogen isotope studies to problems of hydrothermal alteration and ore deposition: Economic Geology, v. 69, p. 843-883.
Truesdell, A. H., 1976a, Chemical evidence of subsurface structure and fluid flow in a geothermal system: International Symposium on Water-Rock Interaction, Prague, Czechoslovakia, 1974, Czechoslovak Geological Survey, Proc.

- 1976b, Geoterm, a geothermometric computer program for hot-spring systems: in Second United Nations Symposium on the Development and Use of Geothermal Resources, San Francisco, 1975, Proc., p. 831-836.

Truesdell, A. H., and Fournier, R. O., 1977, Procedure for estimating the temperature of a hot-water component in a mixed water by using a plot of dissolved silica versus enthalpy: U.S. Geological Survey Journal of Research, v. 5, no. 1, p. 49-52.

U.S. Geological Survey, 1976, Water resources data for Oregon, Water year 1975: U.S. Geological Survey Water-Data Report OR-75-1, $586 \mathrm{p}$

White, D. E., 1968, Hydrology, activity, and heat flow of the Steamboat Springs thermal system, Washoe County, Nevada: U.S. Geological Survey Professional Paper 458-C, 109 p.

- 1970, Geochemistry applied to the discovery, evaluation, and exploitation of geothermal energy resourcs: U. N. Symposium on the Development and Utilization of Geothermal Resources, Pisa, 1970, in Geothermics, Special Issue 2, p. 58-80.

Williams, Howel, 1949, Geology of the Macdoel Quadrangle: San Francisco, California Department of Natural Resources: Division of Mines Bulletin 151, p. 7-60.

Wood, P. R., 1960, Geology and ground-water features of the Butte Valley region, Siskiyou County, California: U.S. Geological Survey Water-Supply Paper 1491, 150 p. 
